Portland State University

PDXScholar

$1-1-1983$

\title{
Metropolitan school administrators: work values, role perceptions and burnout
}

Jacqueline Conner Waggoner

Portland State University

Follow this and additional works at: https://pdxscholar.library.pdx.edu/open_access_etds Let us know how access to this document benefits you.

\section{Recommended Citation}

Waggoner, Jacqueline Conner, "Metropolitan school administrators: work values, role perceptions and burnout" (1983). Dissertations and Theses. Paper 826.

https://doi.org/10.15760/etd.826

This Dissertation is brought to you for free and open access. It has been accepted for inclusion in Dissertations and Theses by an authorized administrator of PDXScholar. Please contact us if we can make this document more accessible: pdxscholar@pdx.edu. 
METROPOLITAN SCHOOL ADMINISTRATORS:

WORK VALUES, ROLE PERCEPTIONS AND BURNOUT

by

JACQUELINE CONNER WAGGONER

A dissertation submitted in partial fulfillment of the

requirements for the degree of

DOCTOR OF EDUCATION

in

PUBLIC SCHOOL ADMINISTRATION AND SUPERVISION

Portland State University

University of Oregon

1983

(C) 1983 Jacqueline Conner Waggoner

Reproduced with permission of the copyright owner. Further reproduction prohibited without permission. 
TO THE OFFICE OF GRADUATE STUDIES AND RESEARCH:

The members of the Committee approve the

dissertation of Jacqueline Conner Waggoner presented October $31,1983$.

APPRQVED :
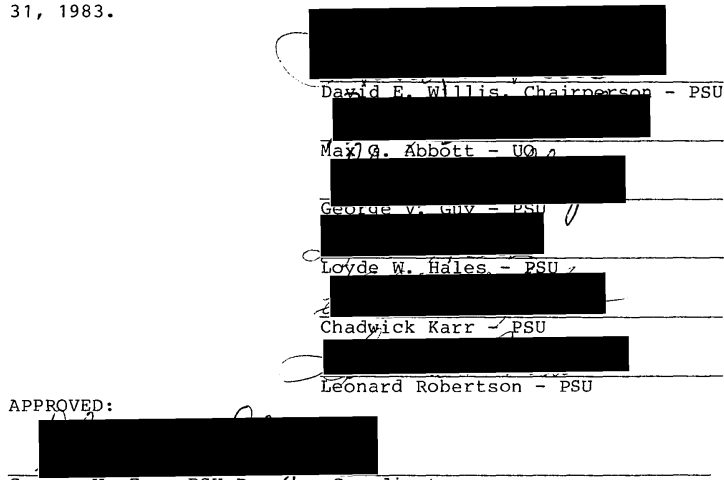

George V. Guy, PSU Progkam Coordinator

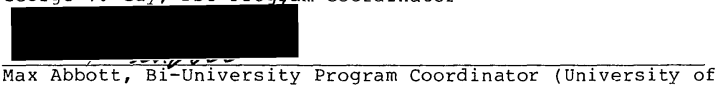
Oregon)

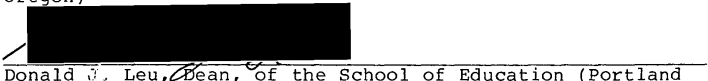

Donald '. Leu, Wean, of the School of Education (Portland State University)

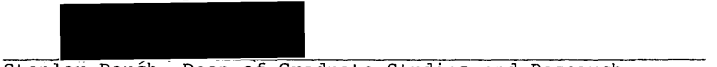

Stanley Raućh, Dean of Graduate Studies and Research (Portland State University) 
AN ABSTRACT OF THE DISSERTATION OF Jacqueline Conner Waggoner for the Doctor of Education in Public School Administration and Supervision presented October 31,1983

Title: Metropolitan School Administrators: Work Values, Role Perceptions and Burnout.

APPROVED BY MEMBERS OF THE DISSERTATION COMMITTEE:

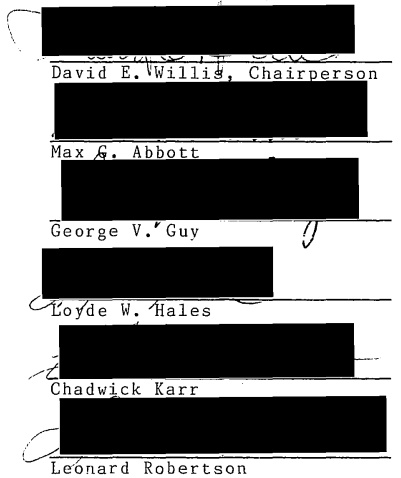

The purpose of this study was to identify the work values of public school administrators (as measured by the Ohio Work Values Inventory, OWVI), and to determine the relationship between public school administrators' role 
perceptions that are associated with burnout (as measured by the Administrator Role Perception Inventory, ARPI), and their work values.

Cluster sampling by district was used; i.e. all administrators within each of ten urban and suburban school districts in Oregon and Washington comprised the initial sample. The responding sample included 388 administrators.

The independent variables of the study were level of administration and the biographical descriptors of sex, age, education, administrative work experience and years of administrative experience at the same job and at the same location. The dependent variables were the seven constructs of the ARPI (Accomplishment, Expectation, Motivation, Psychophysical State, Relationships, Time and Total ARPI) and the 11 constructs of the OWVI (Altruism, Control, Ideas/Data Orientation, Independence, Money, Object Orientation, Prestige, Security, Self-realization, Solitude and Task Satisfaction).

The results indicated only moderate burnout in administrators in the sample and no statistically significant differences in the burnout among different levels of administration, indicating administrators were coping adequately with stress factors at time of year assumed to be particularly stressful, and administrators at the building levels and in the central office reflected similar degrees of burnout.

Reproduced with permission of the copyright owner. Further reproduction prohibited without permission. 
There were no statistically significant sex differences in administrator, indicating male and female administrators can be expected to reflect similar degrees of burnout.

There were no statistically significant differences in nine of the 11 work values measured. Women administrators assigned statistically significantly more importance to the work values of Self-realization (preferring work that permits the individual to utilize his or her skills, abilities or talents and allows for continued personal growth) and Ideas/Data (preferring to work with facts and ideas and creating and communicating ideas).

In total, there were 35 statistically significant correlations between the OWVI scales and the ARPI subscales and the Total ARPI scale, indicating there are statistically significant relationships between administrator work values and role perceptions associated with burnout.

Analyses of variance indicated statistically significant differences between three work values of central office administrators and elementary school administrators, with central office administrators assigning statistically significantly more importance to the work values of Prestige and Independence and statistically significantly less importance to Altruism than did elementary school administrators. Additionally, central office administrators assigned statistically significantly more importance to Independence than

Reproduced with permission of the copyright owner. Further reproduction prohibited without permission. 
did administrators at the Middle/Junior High Schools and High Schools.

Administrators assigned the greatest importance to the work value of Task Satisfaction, indicating respcndents assigned great importance to work that is interesting and enjoyable. The work value of Solitude was valued the least of the 11 work values measured, indicating little importance was given to a job in which the administrator had few or brief structured encounters with other individuals. Administrators assigned considerable importance to the work values of Altruism, Independence and Ideas/Data.

Administrators assigned moderate to considerable importance to the work value of Money. In fact, the mode for this scale was 35 , the highest possible score. However, the scale of Money was not statistically significantly correlated with any of the ARPI subscales nor with the Total ARPI scale, indicating administrative burnout is not related to the importance individuals assigned to Money.

Examination of the reliability and validity measures of the OWVI and ARPI indicated both instruments have satisfactory reliability and validity with the sample population.

Reproduced with permission of the copyright owner. Further reproduction prohibited without permission. 


\section{ACKNOWLEDGEMENTS}

It is impossible to name individually all the people who provided me support and help during my doctoral program. Their love, understanding and encouragement were essential for the completion of my doctorate. I will mention only some of the more special people.

I would like to thank the members of my Dissertation Committee: Dr. David Willis, chairman; Dr. Loyde Hales, Dr. Leonard Robertson and Dr. George Guy from Portland State University and Dr. Max Abbott from the University of Oregon. These gentlemen provided many hours of their time and support.

Also, I would like to thank the administrators from the ten participating school districts who provided data during a very busy time of the year.

Most of all, I wish to thank all of my family, especially Rich, Jill, and Kathy Waggoner, Art and Wally Conner, and Paul and Nola Waggoner for their love, understanding, encouragement and support.

Reproduced with permission of the copyright owner. Further reproduction prohibited without permission. 
TABLE OF CONTENTS

PAGE

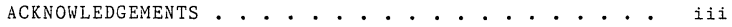

LIST OF TABLES . . . . . . . . . . . . . . . . viii

CHAPTER

I INTRODUCTION . . . . . . . . . . . . 1

Statement of the Problem . . . . . . 5

Importance of the Study . . . . . . 7

Theoretical Foundations and

Assumptions . . . . . . . . . . 10

Definitions of Terms ........ 13

Summary . . . . . . . . . . 18

II REVIEW OF THE LITERATURE . . . . . . . . . . 19

Work Values ........... 20

Historical Perspectives

Vocational Interests \& Personality Theory

Values

Definition of Values

Values and the World of Work

Definitions of Work Values

Importance of Studying Work Values

Measurement of Work Values

Summary of Work Values

Stress............ . . 38

Introduction

Definitions of Stress

Stressors

Job Stress

Effect of Stress in Work Environment

Reproduced with permission of the copyright owner. Further reproduction prohibited without permission. 
Stress and the Individual

Summary of Stress Literature

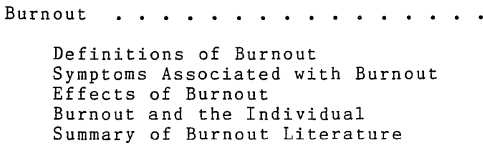

Definitions of Burnout

Symptoms Associated with Burnout

Effects of Burnout

Burnout and the Individual

Summary of Burnout Literature

Related Factors with Stress, Burnout and

Work Values .. . . . . . 60

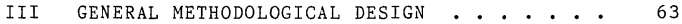

Design of the Investigation . . . . . 64

Instrumentation . . . . . . . 65

Data Gathering Procedures . . . . . 70

Statistical Design . . . . . . . 71

Summary . . . . . . . . . . . 72

IV PRESENTATION OF THE FINDINGS . • • • • • • $\quad 74$

Sample. . . . . . . . . . 74

Size

Description

Scoring of the OWVI . . . . . . 85

Analysis of the Scales of the OWVI . . 86

Summary of the Scores

Altruism

Object Orientation

Security

Control

Self-realization

Independence

Money

Task Satisfaction

Solitude

Ideas/Data Orientation

Prestige

Summary 
Scoring of the ARPI . . . . . . . 104

Analysis of the Subscales of the

ARPI and the Total ARPI . . . . 105

Summary of the Scores

Expectation

Motivation

Psycho-physical State

Relationships

Accomplishment

Time

Total ARPI

Summary

Relationships Between Instruments and

Biographical Data . . . . . . 116

Relationships Between Biographical Data and ARPI

Summary of Statistically Significant Correlations

Relationships Between Biographical Data and OWVI

Summary of Statisticaly Significant Correlations

Relationship Between OWVI and ARPI

Summary of Statistically Significant Correlations

Relationship Between OWVI, ARPI and Subject's Sex

Summary of Sex Differences

Relationship Between OWVI, ARPI and Job Location

Summary of Job Location Differences

Measurement Characteristics of the

Instruments Used . . . . . . . . 133

Ohio Work Values Inventory

Summary

Administrator Role Perception Inventory

Summary

Sunmary . . . . . . . . . . 145

Conclusions . . . . . . . . . 149 


\section{LIST OF TABLES}

TABLE

PAGE

I Origin of Variables . . . . . . . . . 11

II Stressors... . . . . . . . . 4 42

II Most Stressful Items . . . . . . . . 45

IV Popular Publications with Articles on

Burnout: $1980-1982$. . . . . . . 51

V Coefficient Alpha for Each OWVI Scale . . . 67

VI OWVI Scale Intercorrelations . . . . . 67

VII Coefficient Alpha for Each ARPT Subscale

and for Total ARPI . . . . . . . 69

VIII ARPI Scale Intercorrelations . . . . . 70

IX Geographical Characteristics and Return

Rate............... 75

$X$ Distribution of Male/Female

Administrators ........ . 76

XI Distribution of Administrators by Age . . . . 77

XII Distribution of Administrators by

Position Type . . . . . . . . . 78

XIII Distribution of Subjects by

Administrative Position . . . . . . 79

XIV Distribution of Administrators by

Job Location . . . . . . . . . 80

Reproduced with permission of the copyright owner. Further reproduction prohibited without permission. 
XV Distribution of Administrators by Years in Present Position . . . . . . . . 81

XVI Distribution of Highest Degree Earned . . . 82 XVII Distribution of Years of Educational Administrator .......... 83 XVIII Distribution of Certificates Held . . . . . . 84

XIX Assignment of OWVI Items to Scales . . . . 85

$\mathrm{XX}$ Means and Standard Deviations for OWVI Scales ........... . . 87

XXI Frequency Distribution of Scores on A1truism........... . . 88

XXII Frequency Distribution of Scores on Object Orientation . . . . . . . . 90 XXIII Frequency Distribution of Scores on Security . . . . . . . . . . . .

XXIV Frequency Distribution of Scores on

Control ...............

XXV Frequency Distribution of Scores on

Self-realization . . . . . . . . . 94

XXVI Frequency Distribution of Scores on Independence . . . . . . . . . 95

XXVII Frequency Distribution of Scores on Money . . 96 XXVIII Frequency Distribution of Scores on Task Satisfaction ......... . 
XXIX Frequency Distribution of Scores on

Solitude............ . . .

XXX Frequency Distribution of Scores on

Ideas/Data . . . . . . . . . . . 100

XXXI Frequency Distribution of Scores on

Prestige.............. . 101

XXXII Assignment of ARPI Items to Subscales . . : . 104

XXXIII Means \& Standard Deviations for Subscales

and Total ARPI . . . . . . . . . 106

XXXIV Frequency Distribution of Scores on

Expectation ........... 107

XXXV Frequency Distribution of Scores on

Motivation . . . . . . . . 108

XXXVI Frequency Distribution of Scores on

Psycho-physical State... . . . . . 109

XXXVII Frequency Distribution of Scores on

Relationships . . . . . . . . 110

XXXVIII Frequency Distribution of Scores on

Accomplishment . . . . . . . . 111

XXXIX Frequency Distribution of Scores on Time . . 112

$\mathrm{XL}$ Frequency Distribution of Total ARPI

Scores.............. . 114

XLI Correlations of Biographical Data

with ARPI ............ . 117

Reproduced with permission of the copyright owner. Further reproduction prohibited without permission. 
XLII Statistically Significant Correlations and

Level of Significance with ARPI . . . . 117

XLIII Correlations of Biographical Data with OWVI . . . . . . . . . 118

XLIV Statistically Significant Correlations and

Level of Significance with OWVI . . . . 119

XLV Correlations Between ARPI and OWVI . . . . 120

XLVI Statistically Significant Correlations Between

OWVI and ARPI and Level of Significance. .

XLVII ANOVA for Self-realization Scale and

Sex of Respondent . . . . . . . . 123

XLVIII Self-realization Scale Group Means . . . . 124

IL ANOVA for Ideas/Dala Scale and Sex of

Respondent . . . . . . . . . . 124

L Ideas/Data Group Means . . . . . . . . 124

LI ANOVA for Altruism Scale and Job Location. . 126

LII ANOVA for Independence Scale and Job

Location ............ 126

LIII ANOVA for Prestige Scale and Job Location. . 127

LIV ANOVA for Relationship Subscale and

Job Location............ . . 127

LV ANOVA for Time Subscale and Job Losation . . 127

LVI Altruism Scale Group Means . . . . . . 128

LVII Independence Scale Group Means . . . . . . 129

LVIII Prestige Scale Group Means . . . . . . . 130 
LIX Relationship Subscale Group Means . . . . . 131

LX Time Subscale Group Means . . . . . . . . 132

LXI Coefficient Alpha for Each Scale on OWVI • • 134

LXII Scale Intercorrelations of OWVI . . . . . 135

LXIII Coefficient Alpha for Each Subscale and

for Total ARPI............ . . 138

LXIV ARPI Subscale Intercorrelations . . . . . 139

LXV Frequency Distribution of Scores on

Job Stress... . . . . . . . . 140

LXVI Frequency Distribution of Scores on

Personal Stress ... . . . . . . 141

LXVII Correlations Between Stress Measures and

Total ARPI Scale.......... 142

LXVIII Frequency Distribution of Scores on

Burnout . . . . . . . . . . 143

LXIX Previous ARPI Means and Standard

Deviations.......... . . 200

Reproduced with permission of the copyright owner. Further reproduction prohibited without permission. 


\section{CHAPTER I}

\section{INTRODUCTION}

The nation's educational system has become a national issue. It is being criticized by citizens on national, state and local levels. School boards and others are close1y examining the schools to determine why students are not achieving excellence in their educational performance. Projects such as "Search for Effective Schools" (Edmonds, 1979) have attempted to identify and analyze schools that are instructionally effective. National Commissions on Excellence in Education have been established to determine factors associated with greater student learning. In the examination of factors leading to positive student performance, literature indicated that the instructional leadership of a school is crucial to the effectiveness of the school (Edmonds, 1979; Clark, Lotto and McCarthy, 1980). It is reasonable, then, to direct research at the administrative levels of school systems to detemine more explicitly how leadership contributes to the effectiveness of schools' educational programs.

One factor that may be affecting public schools is a change in the work values of American workers. Some workers appear to be alienated, reflecting a general unhappiness in 
work settings or a lack of commitment to productive outcomes. Since management has an interest in productive workers, organizations are attempting to identify the current work values of their employees in order that the organizations may implement management practices that are compatible with those values (Howard, 1981). Employees whose work values are violated in job settings can feel stress which ultimately leads to burnout.

Research on stress and burnout has indicated that an individual's values may be related to stress and burnout (Persson and Sjoberg, 1978; Conper, 1981; Levinson, 1981; Norman, 1981). For instance, the values of Task Satisfaction and Self-realization, as defined in the Definition of Terms, may be related to burnout. Individuals desiring to realize more than just a paycheck from a job may be determined idealists who have a higher need to do the job well for its own sake. These individuals tend to be more prone to burnout. Other values that may be linked to burnout are described in the review of the literature.

Research on the subject of stress has been ongoing for over 40 years, beginning with the work of Hans Selye, first at McGill University, and then at the University of Montreal's Institute of Experimental Medicine and Surgery. Since Selye's (1936, 1946) initial research, thousands of separate reports on stress research have been published as well as a great number of books. Stress is discussed in

Reproduced with permission of the copyright owner. Further reproduction prohibited without permission. 
both popular and academic literature. The simplest and most generally-accepted definition of stress, according to Selye (1976), is the "nonspecific response of the body to any demand" (p. 472). Research has documented the detrimental costs of stress in terms of the serious mental and/or physical illnesses that can result from inadequate coping with stressors. The U. S. National Clearing House for Mental Health Information has placed a monetary value upon the decrease in the productive capacity of workers who are suffering the effects of debilitating stress (Swent and Gmelch, 1977).

Since approximately 1974, the term "burnout" has begun appearing in the literature. Burnout may be described as a syndrome of physical and emotional exhaustion involving a development of a negative self-concept, negative job attitudes and a loss of feeling for the individuals or clients served (Freudenberger, 1975; Maslach and Pines, 1977; Kahn, 1978; Pines and Maslach, 1978). Although this term had been defined in the dictionary before 1974 (Gove, 1961), referring to a process of failing, wearing out or becoming exhausted due to the excessive demand made upon one's energy, strength and resources, it was not used in the study of stress until approximately 1974, after which time several authors began to use the term in reference to staff who displayed a specific set of physical and behavioral signs indicating the staff person had begun to "wear out" (Kahn,

Reproduced with permission of the copyright owner. Further reproduction prohibited without permission. 
1978; Maslach, 1978; Gentile and McMillan, 1980; Ricken, 1980; Veninga and Spradley, 1981). Subsequently, research has developed to help explain the burnout response to prolonged and excessive stress (Freudenberger, 1975, 1977; Chance, 1981; Levinson, 1981; Maslach \& Jackson, 1981).

Since burnout is painful, personally destructive and costly to organizations in terms of excessive absenteeism and inefficiency on the job, many researchers have studied the phenomenon. Their studies have defined the term "burnout," listed its causes and symptoms and identified those people who might be prone to burnout. Additionally, various authors (McGhee, 1963; Mclean, 1974; Se1ye, 1976; Cooper, 1981; Gherman, 1981) have suggested strategies to cope with stressors in order to prevent burnout.

Burnout may be one factor negatively affecting our public schools according to several authors (Ricken, 1980; Lipovenko, 1981; Morrow, 1981; Wax, 1983). Burnout among public school administrators can have a devastating effect upon the education of children, since burned-out individuals withdraw and distance themselves from children, peers and parents. Burnout has been found to be a significant factor in poor job performance, high absenteeism and a lack of employee motivation on the job in other professional fields. This research, then, was directed at the administrative level of school systems in order to provide data on administrator work values and role perceptions that would be useful

Reproduced with permission of the copyright owner. Further reproduction prohibited without permission. 
in increasing administrator productivity and would be useful in reducing administrator burnout.

\section{Statement of the Problem}

The problem was to identify the work values of public school administrators, as measured by the Ohio Work Values Inventory (OWVI), and to determine the relationship between public school administrators' role perceptions that are associated with burnout, as measured by the Administrator Role Perception Inventory (ARPI), and their work values. The data of this study were analyzed as indicated below.

I. By Levels of Administration. Are there significant differences in work values and administrator role perceptions when comparisons are made by different levels of administration?

II. By Background Data. Are there significant differences in work values of administrators and role perceptions of administrators that are associated with burnout when comparisons are made by
A. Sex of administrator?
B. Age of administrator?
C. Education of administrator?
D. Administrative work experience of administrator in the fietd of education?
E. Years of administrative experience at present position?

Reproduced with permission of the copyright owner. Further reproduction prohibited without permission. 
III. By Specific Scales on the Instruments. What are the relationships between specific scales on the Administrator Role Perception Inventory and specific scales on the Ohio Work Values Inventory?

Levels of administration were analyzed to determine whether stress and burnout were more prevalent in the central office versus the building level, at the high school level versus the middle school/junior high or elementary levels, etc. If there is more stress at higher levels of administration, there is a greater likelihood for individuals at these levels to experience burnout. Additionally, the work values may be different at different levels of an organization (Centers, 1949; Rosen and Weaver, 1960; Porter, 1961), and an individual's work values may affect the propensity to burn out (Levinson, 1981). Research also has indicated individuals in higher levels of organizational hierarchies have greater responsibilities and may be subject to more stress (Greenwood and Greenwood, 1979). One's job responsibilities, then, could be a factor in burnout in terms of the level of job responsibilities, stress and work values of the individuals.

Background data of administrators were analyzed to determine whether there were significant relationships between such data and an individual's work values and level of burnout. Previous research has found that there is a positive relationship between age and emotional exhaustion

Reproduced with permission of the copyright owner. Further reproduction prohibited without permission. 
(Wax, 1983). Analysis of male versus female role perceptions and work values provided data as to whether the women administrators in the sample experienced similar burnout and possessed similar work values as their male counterparts. Also, it has been postulated that individuals who do the same job over a long period of time at the same work site may be more prone to burnout related to the length of tenure in a position. This study provided data to help determine whether there are significant differences in work values and role perceptions of administrators who show signs of burnout.

Specific scales on the instruments were analyzed to determine the relationships between the six subscales and the Total ARPI scale on the Administrator Role Perception $\underline{\text { Inventory and the eleven scales on Ohio Work Values }}$ Inventory in order to determine which work values may be related to burnout. Previous research suggested that there may be relationships between one's burnout and one's value for control, self-realization, prestige, task satisfaction, altruism and solitude (Freudenberger, 1974, 1975; Freudenberger and Richelson, 1980; Levinson, 1981; Norman, 1981; Pines, Aronson and Kafry, 1981; Wax, 1983). This study provided data as to whether such relationships exist.

\section{Importance of the Study}

Burnout may have important implications for the public 
schools. Burned-out professionals lack motivation for their work, and burnout leads to a high degree of costly turnover and absenteeism. Additionally, burnout has been said to be a significant factor in low worker morale, poor performance, and the poor delivery of services to people who need them. As Maslach and Pines (1979) stated about burnout, "Furthermore, it is correlated with other negative indexes of personal stress, such as alcoholism, mental illness, and marital conflict" (p. 247). Burnout is harmful both personally and professionally to educators, and the existence of administrator burnout could adversely affect the leadership in our public schools.

Although burnout among public school administrators may be devastating to our schools, administrator burnout is just beginning to be researched. In fact, research using the Administrator Role Perception Inventory began in August of 1982 when members of the Confederation of Oregon School Administrators (COSA) completed the inventory. Instead, studies in the field of education have concentrated on teacher burnout and the accompanying detrimental effect upon student achievement. Additionally, burnout among policemen, social-welfare workers, social workers, social-service workers, psychiatric nurses, poverty attorneys, college teachers, childcare workers, clinical psychologists and psychiatrists in a mental hospital, supervisors of institutions for the mentally retarded, some prison 
personnel, and physicians has been investigated with the Maslach Burnout Inventory (Maslach and Pines, 1979).

Research in the area of administrator burnout and work values is useful in the following respects.

1. This information will help administrators identify the warning signs of burnout in themselves and in their coworkers in order that they may take steps to counteract the effects of burnout and respond more effectively to those who are experiencing problems associated with burnout.

2. Knowledge about factors contributing to burnout among administrators can help school districts restructure activities in order that the work environment will help to satisfy better the needs of administrators.

3. Many scholars (Gooding, 1972; Sheppard and Herrick, 1972; Editorial Research Reports, 1973; Special Task Force, 1973; Tarnowieski, 1973) have inferred from, their studies that fundamental changes are taking place in the traditional beliefs held about work as a human activity. In order to respond to these changes taking place in employee work values and to elicit the maximum productivity and creativity from management personnel, school districts need to know the work values of their administrators.

4. Work value theorists postulate it is possible to predict how employees will react to a given situation. That is, the favorableness of employee response to certain job tasks and leadership styles can be predicted depending upon

Reproduced with permission of the copyright owner. Further reproduction prohibited without permission. 
one's work values. This knowledge can be used to help make the employees more happy and more productive on the job (Howard, 1981).

5. An understanding of administrator work values may help school districts more clearly understand managerial motivation.

6. An understanding of one's own work values can help administrators understand people with differing values.

7. Information on administrator work values can aid in the development of an adequate reward system.

8. An understanding of one's work values can help the school administrator understand stress factors in the job setting when the job setting does not allow one to achieve those job values.

9. An understanding of work values and burnout can aid districts in the development of inservice programs to help administrators deal more effectively with the stress and demands of their jobs.

10. The accumulation of empirical information in the field of administrator job burnout and work values can lead to hypotheses and subsequent formalized theories about these topics, as the information from this research will provide baseline data for further research.

Theoretical Foundations and Assumptions

According to the authors of the Ohio Work Values

Reproduced with permission of the copyright owner. Further reproduction prohibited without permission. 
Inventory, (Hales and Fenner, 1973), which is the instrument employed in this research to measure administrator work values, the theoretical foundations of the OWVI can be traced to the following: The personality theory of Horney (1945); the personality-need theory, as postulated by Maslow (1954) and adapted to an occupational choice theory by Roe (1956); worker functions, identified by the United States Department of Labor; self-theory, as presented by Combs and Snygg (1959); and an analysis of the values used in previous investigations.

The following authors' research provided a foundation for the formulation of the variables associated with the measurement of administrator role perceptions, according to the authors of the Administrator Role Perception Inventory (Hales and Wax, 1982), presented in a table developed by Wax (1983).

\section{TABLE I}

ORIGIN OF VARIABLES

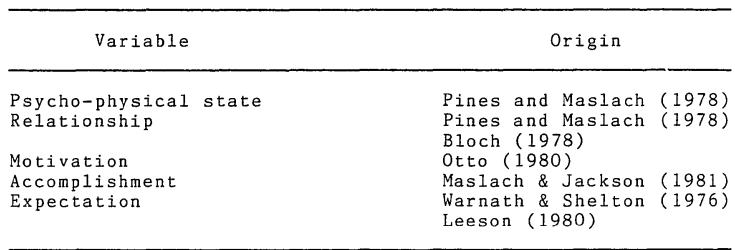

Reproduced with permission of the copyright owner. Further reproduction prohibited without permission. 
The variable called "negative time orientation"--a longing for the "good old days"--also is included by the authors in the Administrator Role Perception Inventory. This variable had not been researched prior to the formulation of the ARPI.

The following assumptions were part of the theoretical foundations of this study.

1. As Mattingly (1977) stated, "'Burn-out' is a painful and personally destructive response to excessive stress" (p. 127).

2. Personality variables contribute to burnout (Freudenberger, 1975).

3. An individual's needs contribute more to job pressure than the reverse (Buck, 1972).

4. Stress is present in everyone's life, but some people have the capacity to handle stressful situations better than others. One's personality traits affects one's reaction to stress (Gherman, 1981).

5. The work values of an individual are associated with one's personality traits and an individual's needs and, therefore, may be related to burnout.

6. School districts want their employees to be productive and creative and experience high morale.

Reproduced with permission of the copyright owner. Further reproduction prohibited without permission. 


\section{Definition of Terms}

The constructs of the Administrator Role Perception Inventory include Psycho-physical State, Relationships, Motivation, Accomplishment, Expectation and Time. These constructs are defined by the authors of the ARPI (Hales and Wax, 1982) as follows.

Accomplishment: The sense of attainment of one's professional goals.

Expectation: The degree of discrepancy between one's reality and one's anticipated reality relative to one's job.

Motivation: The propensity to initiate action; the inclination toward proactivity.

Psycho-physical State:

The overall mental, emotional, and physical vigor and resilience of an individual.

Relationships: The desire for and the quality of the continuous interaction with workrelated colleagues and clients; and the acceptance of oneself by clients and colleagues.

Time: The tendency to view the past as better than the present; a longing for the "good old days". A high score indicates a "present" orientation.

Reproduced with permission of the copyright owner. Further reproduction prohibited without permission. 
The following are the definitions of the constructs of the Ohio Work Values Inventory employed in this study (Hales \& Fenner, 1973).

Altruism:

Contro1:

Ideas/Data Orientation:
Signifies the importance given to the opportunity for involvement with other people in helping, supportive or service roles. A quality of interpersonal giving by the valuer characterizes the relationships that are developed in the work.

Indicates the importance of having an opportunity to take a leadership role or responsibility for other workers in the conduct of their work. The job itself gives the person an influencing or decision-making role with regard to the planning, supervision and evaluation of workers.

Indicates the importance of having an
opportunity to work with facts and
ideas. A high score on this scale
signifies a preference for dealing
with, making sense out of, creating
and communicating ideas.

Reproduced with permission of the copyright owner. Further reproduction prohibited without permission. 
Independence: Signifies the importance of work that allows the person to determine his own working conditions. A high score on this scale indicates a preference to be free from close supervision and to structure one's own hours and methods of working. An element of control-the desire for mastery over the work environment--is expressed in this value.

Money:

Indicates the importance of work that enables the person to have a substantial income--more than enough to assure basic needs. The value reflects a materialistic outlook--one in which the person's desires for m Lerial satisfactions and psychological gratifications attendant upon wealth can be realized.

Object

Orientation: Expresses the valuation of handiing, tending or manipulating physical objects such as utensils, materials, tools or apparatuses. The value relates to work that involves making, fixing, operating or changing the appearance of things

Reproduced with permission of the copyright owner. Further reproduction prohibited without permission. 
things, the results of which tend to be readily apparent and measurable.

Prestige: $\quad$ Concerns the desire for work that will bring a person recognition. An aspect of this value is the opportunity to meet or associate with important people.

Security: Concerns the desire for work that is steady and dependable. The work may be fulltime, parttime or seasonal; but it is quite immune to unpredictable layoff or dismissal.

Selfrealization:

Expresses a preference toward work permitting the individual to utilize his skills, abilities or talents. The work allows for continued personal growth and realization of one's full potential.

Solitude: Related to the preference for work situations characterized by the absence of close relationships with other people. The work can be done largely by one person, and it usually affords either few or brief structured personal encounters.

Reproduced with permission of the copyright owner. Further reproduction prohibited without permission. 
Task

Satisfaction: Concerns the importance associated
with work that generally is
interesting and enjoyable. The work
tasks are the kind that an individual
can, for the most part, look forward
to doing.

The following are the operative definitions of administrator role perception, burnout and work value used in this research.

Administrator

Role Percep-

tion:

The administrator's unique and private perception of his or her phenomenological world in terms of expectation, motivation, accomplishment, relationships, psycho-physical state and time orientation (Wax, 1983, p. 83).

Burnout:

A syndrome of physical and emotional exhaustion involving a development of negative self-concept, negative job attitudes, loss of concern and feeling for clients (Maslach, 1978).

Work Va1ue:

The empirically measured tendency to react favorably to certain generalized conceptions about work (Fenner, 1972, p. 13).

Reproduced with permission of the copyright owner. Further reproduction prohibited without permission. 


\section{Summary}

This study of administrator burnout, which is a syndrome of physical and emotional exhaustion involving the development of a negative self-concept, negative job attitudes and loss of concern and feeling for clients (as measured by the Administrator Role Perception Inventory), as it relates to work values (as measured by the Ohio Work Values Inventory), contributes to research on stress and burnout. The results of this study should help administrators identify warning signs of burnout in themselves and in their coworkers, help school districts structure activities in order that the work environment will better satisfy the needs of administrators, and contribute to the body of empirical information in the field, leading to subsequent formalized theories about the topics of administrator burnout and administrator work values.

The data from this study were analyzed by levels of administration, by background data and by specific scales on the Administrator Role Perception Inventory and the Ohio Work Values Inventory.

Reproduced with permission of the copyright owner. Further reproduction prohibited without permission. 
CHAPTER II

\section{REVIEW OF RELATED LITERATURE}

A survey of the literature revealed that there has not been any systematic study of the relationship between school administrators' work values and burnout. However, the two variables have been researched independently. There is a considerable amount of research on the topic of stress that can lead to burnout. As Gherman (1981) stated

Over 6,000 separate reports on stress research have been made in recent years, and the largest and most comprehensive stress documentation center in the world, at the International Institute of Stress in Montreal, Canada, houses over 120,000 volumes on the subject. (p. 4)

Since 1974, several authors have conducted research and have written specifically about the subject of burnout (Freudenberger, 1974, 1975, 1977; Maslach and Pines, 1977, 1979; Matting1y, 1977; Kahn, 1978; Maslach, 1978; Pines and Maslach, 1978, 1980; Gann, 1979; Leeson, 1980; Neville, 1981; Norman, 1981; Pines, Aronson, Kafry, 1981; and Wax, 1983). These authors and others will be included in the review of literature. Additionally, the variable of work values has been researched extensively in the literature. Some of the leading research in this field has been conducted by Holland, 1966; Super, 1968; Hales and Fenner, 1973; Hales and Yackee, 1974; and Hales and Hartman, 1977.

Reproduced with permission of the copyright owner. Further reproduction prohibited without permission. 
The related literature, as developed in this chapter, begins with the research on work values. Next, relevant research pertaining to stress and burnout is reviewed. Finally, the related factors associated with stress, burnout and work values will be discussed.

\section{Work Values}

The review of the research of work values begins with an historical perspective of the study of workers and their behaviors. Next, the study of vocational interests and their relation to personality theory is discussed. Then, the area of values is explored, including how values theory was applied to the world of work. Finally, literature about the measurement of work values is reviewed.

\section{Historical Perspectives}

The interaction between work and workers has been studied by psychologists for over half a century. In 1913, Munsterberg's textbook titled The Psychology and Industrial Efficiency was a landmark in terms of the beginning of psychologists' concern with work behavior. At that time, however, Munsterberg and others focused research upon techniques concerned with personnel selection and placement and upon improving the physical aspects of the work environment.

In the late $1930^{\prime} \mathrm{s}$ research began to be directed 
toward investigating the relationship of employee attitudes to the work situation. The Hawthorne studies (Roethlisberger and Dickson, 1939) began this movement of investigating employee attitudes. Subsequent work by Lewin (Lewin, Lippit and White, 1939) and Coch and French (1948) began to emphasize the significance of one's attitude and feelings toward one's work. By 1957, Herzberg, Mausner and Snyderman cited several hundred studies of workers' job attitudes and found many studies that focused upon the relationship between workers' job attitudes and their job behavior. For the most part, however, the reviews by Herzberg et al. (1957) and Brayfield and Crockett (1955) were void of studies concerned with the job attitudes of managers. It was not until the early $1960^{\prime}$ 's that the job attitudes of managers were studied on a large-scale basis. Rosen and Weaver (1960) and Porter (1961) were the forefathers of the movement to study the job attitudes of managers. A review of this literature can be found in Porter and Lawler (1965) and Vroom (1965).

Vocational Interests and Personality Theory

Another area of research concerning workers and the work environment correlated job preference to personality factors. Vocational interest inventories were constructed as a means of reinterpreting vocational interests as an expression of personality. Initially, some writers 
indicated that vocational interests were different from or independent of an individual's personality. Research of Strong (1943), Super and Crites (1962), and Campbell (1971) reflected this early view that vocational interest inventories were different from an individual's personality and measure only interest, vocational choices, and vocational preferences. Vocational interests were not considered to be an expression of personality.

Recently, research about the personal and environmental factors associated with vocational choice, job changes, and vocational achievement has indicated vocational preferences are sometimes moderately correlated with personality and originality scales (Holland, 1963). Also, vocational preferences have been found to be correlated with selfratings of ability, personality traits, life goals (Baird, 1970), parental attitudes (Medvene, 1969), objective perceptual tests (Crutchfield, Woodworth and Albrecht, 1958), and many other psychological and sociological variables.

Some writers have indicated vocational preferences and interests needed to be viewed more comprehensively than the aforementioned authors. Bordin (1943) suggested that inventory scores measure one's self concept. Darley and Hagenah (1955) indicated that vocational interest measurement should be considered a special case in the research of personality theory. Or, as Holland (1973)

Reproduced with permission of the copyright owner. Further reproduction prohibited without permission. 
wrote, "In short, what we have called 'vocational interests' are simply another aspect of personality" (p. 7). In discussing the Holland Vocational Preference Inventory (1958, 1965), Holland (1965) presented the following rationale which contains a more complete statement of the hypothesis that vocational interest inventories are personality inventories.

The choice of an occupation is an expressive act which reflects the person's motivation, knowledge, personality, and ability.

Occupations represent a way of life, an environment rather than a set of isolated work functions or skills. To work as a carpenter means not only to use tools but also to have a certain status, community role, and a special pattern of living. In this sense, the choice of an occupational title represents several kinds of information: the $S^{\prime} s$ motivation, his knowledge of the occupation in question, his insight and understanding of himself, and his abilities. In short, item responses may be thought of as limited but useful expressive or projective protocols. (p. 2)

Other key assumptions made by Holland (1973) in regard to vocational preference inventories are as follows.

1. Vocational stereotypes have reliable and important psychological and sociological meanings.

2. The members of a vocation have similar personalities and similar histories of personal development.

3. Vocational satisfaction, stability, and achievement depend on the congruence between one's personality and the environment...in which one works. (p.9)

Job attitude research in industry is an extension of - attitude research, in general, which was conducted in an 
effort to provide important insights into human cognitive processes and contribute to the understanding and prediction of human behavior. Porter (1968) focused research on managerial job attitudes, since the "pervasiveness, importance, and complexity of the managerial job demand that we learn as much as possible about it" (p. 3). Porter (1968) stated the importance of studying managerial effectiveness in writing, "Increased knowledge in this area may lead to applications that will improve the effectiveness of organizations" (p. 3 ).

\section{Values}

Combs and Snygg (1959) address the topic of values, suggesting that an individual's value system interrelates with his self concept to form a part of his phenomenal self. Values are perceived to be more pervasive and permanent than interests and attitudes. In discussing an individual's phenomenal self, Combs and Snygg (1959) said

Those perceptions about self which seem most vital or important to the individual himself are organized in the self concept....such fundamental aspects of his phenomenal self that they seem to the individual to be "he" in all times and at all places. (p. 123)

- Also, values have been related to an individual's needs. Katz (1963) stated that values may be regarded as characteristics, outer expressions and culturally influenced manifestations of needs (p. 16). Osipow (1968) clarified the differences between values and needs in writing

Reproduced with permission of the copyright owner. Further reproduction prohibited without permission. 
Values are assumed to be different from needs, yet influence behavior in similar ways. The primary difference between needs and values seem to be in their origin, needs seem to be thoroughly intrinsic to the individual, though they have social aspects, whereas values are predominantly social though they are built upon one's fundamental personality structure. (p. 152-153)

Worthen (1965) elaborated on the relationship between values and personality. "Some values are so fundamental to a particular personality structure that any attempt to compromise seems to do considerable damage" (p. 9).

\section{Definition of Values}

Values have been defined variously by numerous authors. A review of the genesis of a value system relating to attitudes, needs and interests may be found in Fenner (1972) and Grace (1974). Grace (1974) indicated that an individual's value system may result from needs, i.e. deficit states. The Florida State Department of Education (1962) wrote that values were standards of judgment on human behavior and are intimately related to what the individual has come to accept as guiding principles for living. Raths, Merrill and Simon (1966) described the impact of values in the determination of action and the effect of one's experiences in reconstructing one's values.

We therefore see values as constantly being related to the experiences that shape them and test them. They are not, for any one person, so much hard and fast verities as they are the results of hammering out a style of life in a certain set of surroundings. After a sufficient amount of hammering, certain patterns of evaluating and 

behaving tend to develop. Certain things are treated
as right, or desirable, or worthy. These tend to become our values. (p. 28)

In 1970, Super defined values as

the qualities which people desire and which they seek in the activities in which they engage, in the situations which they live, and in the objects they make or acquire. ( $\mathrm{p} .4$ )

Urban (1930) stated that values satisfy human desire, aid in an individual's development and lead to selfrealization. Therefore, values can be viewed as motivating forces for behavior, important determinants of the stimuli to which a person pays attention.

Fenner (1972) stated that values have the following characteristics.

1. They serve as judgment standards and criteria.

2. They result from and are constantly being reconstructed within the person by means of a dynamic process;

3. They seem to involve both needs of the individual and valuations of the culture;

4. They tend to have abiding rather than transitory meaning to the person; and

5. They have generalized, inclusive, molar nature rather than specific, concrete, structured character. ( $p .24$ )

Values and the World of Work

Values associated with the world of work have been of interest to several researchers. In 1949 , Centers proposed that class membership was a determinant factor in work values of employees. Centers found that the middle class 
desired jobs offering self-expression, while the working class desired jobs offering security.

Elements of autonomy, opportunity for personal growth, and interesting work were more highly correlated with overall job satisfaction than security or pay, according to Sheppard and Herrick (1972).

In their research of expectancy theory, Hackman and Lawler (1971) identified three propositions that are relevant to the study of work values.

1. To the extent that an individual believes that he can obtain an outcome he values by engaging in some particular behavior or class of behaviors, the likelihood that he will actually engage in that behavior is enhanced. Relevant valued outcome can be both intrinsic (e.g., feelings of accomplishment or of personal worth) and extrinsic (e.g., material goods); the only requirement is that the outcome be valued by the individual.

2. Outcomes are valued by individuals to the extent that they satisfy the physiological or psychological needs of the individual, or the extent that they lead to other outcomes which satisfy such needs or are expected by the individual to do so.

3. Most lower level needs (e.g., physical wellbeing, security) can be (and often are) reasonably well satisfied for individuals in contemporary society on a continuing basis....This is not the case, however, for certain higher order needs (e.g., needs for personal growth and development or for feelings of worthwhile accomplishment). (p. 262)

Higher order need satisfactions can be seen both as: (a) a result of (rather than a determinant of) effective performance (Lawler and Porter, 1967), and (b) an incentive for continued efforts to perform effectively (Hackman and 
Lawler, 1971). Individual higher order need strength moderates the relationship between job level and satisfaction. In particular, individuals with higher order need satisfaction respond much more positively to high level jobs than do individuals who have weaker higher order needs. This finding has implications for those of the scientific management persuasion who "have tended to assume that the typical employee will be content, if paid judiciously for his cooperation, to work jobs which provide little or no opportunity for personal feelings of accomplishment or achiẹvement" (Hackmán and Lawler, 1971, p. 280), and those of the job enlargement school who have "tended to assume that most employees are desirous of such opportunities and will work hard and effectively when they have a job which provides them" (Hackman \& Lawler, 1971, p. 280).

\section{Definitions of Work Values}

Work values have been variously labeled as occupational values, job values, and vocational values as well as work values. Each investigator has defined the term in his or her research. Fenner (1972), one of the co-authors of the Ohio Work Values Inventory (Hales and Fenner, 1973), using Schwarzweller's (1960) definition of an occupational value, defined a work value as "the empirically measured tendency to react favorably or unfavorably to certain generalized conceptions about work" (p. 13). Perrone (1965) adopted the aforementioned definition of Schwarzweller, also. Stefflre

Reproduced with permission of the copyright owner. Further reproduction prohibited without permission. 
(1962) wrote that "a vocational value represents a desired style of life as it is determined by the work done by an individual" (p. 1). Miller (1954) described values as "objects, ideas, or activities which the individual perceives as important to his future welfare or selfenhancement" ( $p$. 192). Chaney (1968) described a work value as "any characteristic of a vocation which leads an individual to attach importance or unimportance to that vocation" (p. 28). Super (1970) defined work values as the "satisfactions which people often seek in their jobs or as a result of their jobs" (p. 3). Therefore, it is evident that the concept of a work value has been defined similarly.

\section{Importance of Studying Work Values}

Researchers have studied many aspects of worker behavior and motivation in an effort to provide data that will lead to a more harmonious employer-employee relationship as well as high productivity. Literature has suggested that a change has taken place in the work environment and that workers are becoming more difficult to manage. Buchholz (1977) stated

There are many indications in American society today which suggest that fundamental changes are taking place relative to the concept of work that dominates our thinking and behavior. (p. 567)

Howard (1981) commented about this difficulty in manaing employees as follows.

It has become something of a truism that employees these days are harder to manage than were their

Reproduced with permission of the copyright owner. Further reproduction prohibited without permission. 
counterparts of a generation ago. They are said to be far less predictable in their attitudes toward pay, supervision and other work-related factors. ( $p$. 118)

Researchers have tried to explain the reasons for this change in employee behavior. As early as 1956, Roe commented that there was a change taking place in the concept of economic man. Roe (1956) stated

The old concept of economic man has proved totally inadequate to explain why men work as they do, or what it is that they are working for. That men work just to make a living is obviously not true. (p. 23)

Bowers and Franklin (1977) used the popular phrase "blue-collar-blues" to describe the alienation phenomenon that appears not to be limited to blue-collar workers. They defined the term as a "human resource malaise of some variety, shape or form, (reflecting) a general unhappiness in work settings or a lack of commitment to productive outcomes" (p. 15). Editorial Research Reports (1973) reported of this discontent in the work place, also. "There is a fear that worker discontent is so pervasive it may undermine the nation's social and economic structure" (p. 1). To help organizations cope with this changing work force, many large companies are attempting to identify the underlying values on which an individual's behavior is based (Howard, 1981).

The importance of understanding job-related human behavior derives from the concept that

work has always been and continues to be the major nonfamily activity that is undertaken by most human

Reproduced with permission of the copyright owner. Further reproduction prohibited without permission. 
beings. For most people, their work is more than just eight hours out of their waking life; it is a way of life that largely determines where they will live, with whom they will associate, and even what their children will become. (Porter \& Lawler, 1968, p. 1)

Super (1953) also remarked on the importance of work. He commented on the importance of satisfying one's work values in terms of one's total life satisfaction in stating

Work satisfactions and life satisfactions depend upon the extent to which the individual finds adequate outlets for his abilities, interests, personality traits, and values; they depend upon his establishment in a type of work, a work situation, and a way. of life in which he can play the kind of role which his growth and exploratory experiences have led him to consider congenial and appropriate. (p. 190)

Centers (1948) also remarked on the importance of studying man in relation to his work environment.

We need to scrutinize man in the context of his work life that his values, his specific desires and aspirations, and his goals will stand revealed in some meaningful relation to it and lay the basis for some prediction and control. (p. 187)

\section{Measurement of Work Values}

Several researchers developed instruments that measure work values. Some of these instruments are: Occupational Rating Scale (Hammond, 1956), Vocational Values Inventory (Stefflre, 1962), Work Values Inventory (Super, 1968), Work Values Inventory, (Miller, 1954) and Ohio Work Values Inventory (Hales and Fenner, 1973). The latter is the most recent and has been employed in a number of studies.

A chief consideration in the measurement of work values is the selection of values to be measured. The values 
measured by the Ohio Work Values Inventory (Hales and Fenner, 1973) were selected after review of various value constructs used in other scales. Fenner (1972) stated that authors have tended to agree that six constructs comprise a base or core group of work values. These values are Money, Security, Independence, Altruism, Prestige and Control. Self-realization may be considered one of the core work values, also, but various authors "differed in its conceptualization in operationally feasible and vocationally relevant terms" (Fenner, 1972, p. 36). All seven of the aforementioned constructs are included in the OWVI. Additionally, four other constructs are included in the OWVI that have appeared directly or by implication in other instruments. These constructs and the number of instruments in which each construct appeared directly or by implication are: Task Satisfaction--5, Ideas/Data--2, Object Orientation--2, and Solitude--2 (Fenner, 1972). Therefore, the Ohio Work Values Inventory may be considered one of the more inclusive of instruments measuring work values.

The 11 scales of the Ohio. Work Values Inventory may be classified according to the scheme developed by Ginsberg (1951). Accordingly, values are classified as intrinsic if they can be realized by the mere doing of the work. According to Fenner (1972), values are classified as extrinsic if their satisfaction is dependent upon factors consequent to or extrinsic to the work. Extrinsic values may be

Reproduced with permission of the copyright owner. Further reproduction prohibited without permission. 
further classified according to situate values that require for their realization the presence or existence of particular conditions or work values that are rewards of the work. Therefore, the 11 scales of the OWVI may be categorized as follows according to Fenner (1972).

I. Intrinsic values
A. Altruism
B. Object Orientation
C. Self Realization
D. Task Satisfaction
E. Ideas/Data Orientation

II. Extrinsic values
A. Rewards of work
1. Control
2. Money
3. Prestige
4. Security

B. Situate

1. Independence

2. Solitude (p. 62)

The Ohio Work Values Inventory (OWVI) has been used in several research studies. Hales and Fenner (1972) investigated the work values of fifth-, eighth-, and eleventh-grade students in three Ohio public schools. A multivariate analysis of variance, using grade level as the independent variable was performed, followed by univariate analyses of variance. The F ratios for the scales of Altruism and Selfrealization were significant, indicating that the fifth- and eighth-grade students more strongly valued altruistic jobs and work permitting self-realization than did the eleventhgrade students in the sample.

Reproduced with permission of the copyright owner. Further reproduction prohibited without permission. 
In 1977 , A. K. Hales researched the work values of practicing nurses and nurses in training. These two groups did not differ significantly. However, the work value profile proved distinctive, indicating that practicing nurses placed considerable value on Task Satisfaction, Selfrealization and Altruism and less strongly valued Prestige, Object Orientation and Solitude.

Hales and Fenner (1973) researched differences in work values in relation to the sex of the respondent. The results indicated females placed greater value on Altruism than the males in the sample. Females placed lesser value on the work values of Object Orientation and Solitude than did the male respondents.

In 1974, Hales and Yackee researched work values in relation to self-concept and sex. The findings indicated females placed less value on object Orientation, Control, Ideas/Data and Prestige than did the males in the sample.

In research of undergraduate students at Ohio University (Hales and Hartman, 1978), seven univariate F ratios were found to be significant. Females placed a higher value on Altruism, Task Satisfaction and Selfrealization than the males, and they placed lesser value on Control, Money, Solitude and Prestige than the males in the sample.

Hales and Hartman (1977) investigated the relationship between work values and personality of 1,072 second-year

Reproduced with permission of the copyright owner. Further reproduction prohibited without permission. 
students in two-year Ohio technical colleges, using the OWVI and Holland's Vocational Preference Inventory (1965). of the 15 pair-wise comparisons made, five were significant. The data indicated that the Social type, in contrast with the Realistic type personality, placed greater value on A1truism and lesser value on Object Orientation. The Investigative and Social type personalities, in contrast with the Enterprising type, placed greater value on Altruism and lesser value on Money and Control. Also, the Social, Realistic and Enterprising types scored low on Solitude, and the Investigative and Artistic types highly valued Prestige, Independence and Ideas/Data.

Most recently, in 1983, Klampe conducted research to identify the work values of secondary school teachers in selected Oregon school districts and to determine differences in work values by subject area taught, using the Ohio Work Values Inventory. All teachers in the sample, regardless of subject area, highly valued Task Satisfaction and Self-realization. In pair-wise mean comparisons, Math/computer Science teachers placed significantly lesser value on Self-realization than did the Business teachers. The data also indicated that female secondary teachers placed lesser value on Object Orientation, Solitude and Prestige than did the males in the sample, and the female teachers placed greater value on Self-realization than did the males in the sample.

Reproduced with permission of the copyright owner. Further reproduction prohibited without permission. 
As indicated, the Ohio Work Values Inventory has been used extensively in several studies measuring work values of different populations. Also, the OWVI may be considered to be one of the more complete work values inventories, measuring a total of 11 work values.

\section{Summary of Work. Values}

The review of the literature concerning work values dealt with historical perspectives, vocational interests and personality theory, values in general, work values, and aspects of the measurement of work values such as selection and classification of values.

Research of the interaction between work and workers has been conducted for over half a century, originally focusing upon techniques concerned with personnel selection. Research did not begin to concentrate upon job attitudes of managers until the early $1960^{\prime}$ 's when the job attitudes of managers were studied on a large-scale basis.

Personality theory can be related to the study of work values. One's occupation is a reflection of an individual's motivation, knowledge, personality and ability, and members of a vocation have similar personality traits and similar histories of personal development.

An individual's values are an expression of his needs; fundamental to his personality structure and are accepted as guiding principles for living. Values are motivating forces for behavior and important determinants of the stimuli to

Reproduced with permission of the copyright owner. Further reproduction prohibited without permission. 
which a person pays attention. Compromising values central to one's particular personality structure could be quite stressful for individuals.

Organizations have been interested in studying work values of employees to help them cope with the changing work force. The lack of fulfillment of one's work values may contribute to the general unhappiness and alienation in some work settings resulting in lower productivity. There is indication that work values other than money may be important factors in job satisfaction.

Work values may be categorized according to whether they are intrinsic or extrinsic. There is a core of seven work values commonly included in work value research. The Ohio Work Values Inventory may be considered to be one of the more inclusive of instruments measuring work values, since it measures a total of 11 work values that have appeared directly or by implication in other instruments that measure work values. The OWVI has been used in several research studies to identify the work values of different populations, including those of fifth-, eighth-, and eleventh-grade students, practicing nurses and nurses in training, undergraduate students at Ohio University, secondyear, technical college students and of secondary school teachers in Oregon. Previous studies have found significant sex differences in the work values of the elementary students, college students and secondary teachers.

Reproduced with permission of the copyright owner. Further reproduction prohibited without permission. 


\section{$\underline{\text { Stress }}$}

The body of literature published on the topic of stress is vast. Gmelch (1977) reported that "over 80,000 articles have been written about stress, 1,000 research projects have been done, and every year 6,000 more publications are catalogued under the heading of stress" (p. 2). This review of the literature presents an introduction to stress, defines the terms stress and stressors, explores job stress for executives and school administrators, and describes the effects of stress on the work environment, the individual and on society. Finally, individual factors that contribute to one's stress tolerance are described.

\section{Introduction}

The topic of stress appeared in very early writings. Gherman (1981) reported that writings from the early fourteenth century mention a man under "so hard stress that his goodness grew the less" and of another man who "had some sickness or other grievance that maketh him stress" (p. 3). Gherman (1981) reported that the British Fortnightly Review in 1883 wrote of "this age of stress and transition" (p. 3). In 1910, Sir William Osler wrote of the relationship between angina pectoris and the hectic pace of life common among the Jewish members of the business community. Formal research in the field of stress began in 1936 when Hans Selye published his first paper on the subject of stress. Selye (1946) also

Reproduced with permission of the copyright owner. Further reproduction prohibited without permission. 
was the first to research the general adaptation syndrome, in an attempt to explain the process of illness related to stress; and in 1950 Selye produced a monumental volume titled Stress.

\section{Definitions of Stress}

Stress, a word derived from Latin, has been defined in various ways. According to Hinkle (1973), in the seventeenth century. stress meant hardship, straits, adversity, or affliction; in the eighteenth century stress referred to force, pressure, strain or strong effort, primarily in relation to an individual's organs or mental powers. More recently, Gherman (1981) defined stress as "the nonspecific response of the body to any. demand made upon it" (p. 4). Gmelch (1977) defined stress as "any action situation that places physical or psychological demand on people" (p. 7). Selye (1976) defined stress as "the state manifested by a specific syndrome which consists of all the nonspecifically-induced changes within a biologic system" (p. 64). However, Selye (1976) also wrote that the simplest and most generally-accepted definition of stress is "the nonspecific response of the body to any demand" (p. 472). Persson and Sjoberg (1978) summarized some of the more important psychological notions in the field of stress by citing the following authors' works. Lazarus, Deese and Osler (1952) proposed that stress occurs when the attainment of some goal is threatened in any particular situation.

Reproduced with permission of the copyright owner. Further reproduction prohibited without permission. 
Cofer and Appley (1964) defined stress as the state in which an organism perceives its well-being to be endangered. McGrath (1970) stated that an imbalance between an organism's capacity and the demands made upon it results in stress. Beier (1951) defined stress as the perception of threat, with resulting anxiety. Finally, Bergstrom (1970) indicated that stress was a generic term for physiological and psychological processes that are caused by physical harm or anticipation of harm to the individual.

Much of the literature on stress identified common symptoms associated with stress. Some of the more commonly identified stress symptoms 1isted by McGhee (1963), Webber (1966), Pettigrew (1972), and Kenton (1974), as reported by Cooper (1981 p. 13) were

a. difficulty in thinking rationally and seeing all aspects of a problem;

b. rigidity of views, prejudice;

c. out-of-place aggression and irritability;

d. withdrawal from relationships;

e. excessive smoking;

f. an inability to relax resulting in excessive drinking or a need for sleeping pills.

Gmelch (1977) reported that terms typically associated with discussions of stress are "anxiety, frustration, strain, conflict, and tension. People also think of stress in terms of pressure situations, uptight feelings, nervousness, personal demands, and other unpleasant 
encounters" (pp. 6-7). However, stress can be viewed in a more positive framework. For instance, the Chinese language has two separate characters representing the concept of stress, depending upon whether one wishes to view stress as a danger or an opportunity. Therefore, stress can encompass both distress (bad or unpleasant) and eustress (good or pleasant). Distress is said to have a detrimental, even pernicious, effect; while eustress can have a beneficial, even exhilarating, effect. Regardless of the form stress takes, it is, in effect, the essence of life. Without stress there is no life (Selye, 1974, p. 32); and failure to react to a stressor is an indication of death.

\section{Stressors}

There are many things that cause stress. In fact, Selye (1976) defined stressors as "that which produces stress" (p. 78). McLean (1974) further explained stressors as "factors which are productive of fear, the threat to one's superego, and those which may stimulate feelings of losing control of oneself" (p. 11). Gherman (1981, p. 17) divided stressors into those that are external versus those that are internal, presented in the following table.

Reproduced with permission of the copyright owner. Further reproduction prohibited without permission. 
TABLE II

STRESSORS

External Stressors

Internal stressors

Natura1 events

People and animals

Institutions

Regulations

Circumstances
Living habits

Attitudes and perception

Emotions

Instincts and drives

Anxieties

Job Stress

Job stress implies so many different factors and processes that it could include a wide variety of events. Margolis and Kroes in McLean (1974) defined job stress as "the condition in which some factor, or combination of factors, at work interacts with the worker to disrupt his psychological or physiological homeostasis" (p. 15). The concept of factors interacting with the worker is of particular importance, as individuals respond to identical job situations in very different ways.

Executive job stress differs somewhat from the stress to which other individuals are subject. By the very nature of their chosen work, executives require a certain degree of power. This power factor contributes significantly to an executive's stress level, according to Greenwood and Greenwood (1979). Another function of executives is the propensity for risk taking. As Greenwood and Greenwood (1979) stated, "Executives bear the 
responsibility for taking risks involving the wealth or welfare of many others--employees, stockholders, taxpayers, customers, other organizations, etc." (pp. 44-45). Also, those at higher levels in an organizational hierarchy have a greater responsibility for interpersonal relationships, often entailing resolving personality and other conflicts of an interpersonal nature. As Greenwood and Greenwood (1979) stated, "The executive, therefore, serves as legislator, educator, mediator, and judge all at once with all of the attendant frustrations involved in each such occupation" (p. 45).

School administrator job. stress results from many demands made upon an administrator. The job stress includes several of the aforementioned factors experienced by executives, as well as some additional stressors. Gmelch (1977) wrote

The problem with being a principal is that often too many responsibilities are accepted and allowed to grow and evolve into over-demanding roles--of controller, disciplinarian, motivator, persuader, fire-fighter, preserver of the culture, curriculum specialist, or parent surrogate--and the principal becomes a role prisoner rather than a person. (p. 4)

Additionally, a school administrator is subjected to an unrelenting pace, brevity of contact with individuals, a variety of tasks to perform and fragmentation due to interrupted tasks, unscheduled meetings and insistent telephone calls. Therefore, the administrator's job in education often does not permit close control over his or

Reproduced with permission of the copyright owner. Further reproduction prohibited without permission. 
her time. The time on the job is characterized by a high degree of interaction with the telephone, scheduled and unscheduled meetings and continual personal contacts. Other stressors for an administrator result from various rules and regulations imposed by outside agencies, such as the state department of education and the federal government, and by the school district, itself, which imposes new policies and procedures to be implemented.

A11 of these factors have implications for the health and welfare of the school administrator. Kornhauser (1965) referred to several research studies that reported a direct relationship between poor mental health and excessive, inconvenient hours, unpleasant working conditions and the necessity to work quickly and expend physical effort in meeting deadlines. Additionally, Wardell, Hyman and Bahnson (1970) reported that responsibility for people rather than responsibility for things was significantly more likely to lead to coronary heart disease. Responsibility for people results in spending more time attending meetings and interacting with others. Swent and Gmelch (1977, p.19) presented the following table of the ten most stressful items for Oregon school administrators.

Reproduced with permission of the copyright owner. Further reproduction prohibited without permission. 
TABLE III

Most Stressful Items

\begin{tabular}{|c|c|}
\hline Rank & Item \\
\hline 1 & $\begin{array}{l}\text { Complying with state, federal, and organizational } \\
\text { rules and policies. }\end{array}$ \\
\hline 2 & Feeling that meetings take up too much time. \\
\hline 3 & $\begin{array}{l}\text { Trying to complete reports and other paper work } \\
\text { on time. }\end{array}$ \\
\hline 4 & $\begin{array}{l}\text { Trying to gain public approval and/or financial } \\
\text { support for school programs. }\end{array}$ \\
\hline 5 & Trying to resolve parent/school conflicts. \\
\hline 6 & Evaluating staff members' performance. \\
\hline 7 & $\begin{array}{l}\text { Having to make decisions that affect the 1ives of } \\
\text { individual people that I know (colleagues, staff } \\
\text { members, students, etc.). }\end{array}$ \\
\hline 8 & $\begin{array}{l}\text { Feeling that I have too heavy a work load, one } \\
\text { that I cannot possibly finish during the normal } \\
\text { work day. }\end{array}$ \\
\hline 9 & Imposing excessively high expectations on myself. \\
\hline 10 & Being interrupted frequently by telephone calls. \\
\hline
\end{tabular}

Other stressful factors for school administrators arise because society's standards for people in the helping professions often are unrealistically high. Leeson (1980) stated, "Society does not like its public servants to be fallible" (p. 27). Yet, the field of education can be difficult. Often positive feedback is rare and promotions and financial rewards are limited. With the tight budgets

Reproduced with permission of the copyright owner. Further reproduction prohibited without permission. 
faced by many school districts, there is stress produced from functioning within inadequate budgets and the need for constantly finding creative ways to make fewer dollars meet the needs of the children. Administrators in public education are in direct, continuous contact with others and are provided little relief from the constant bombardment of potentially stressful stimuli. Therefore, the school administrator's job has the potential for being extremely stressful and demanding.

\section{$\underline{\text { Effect of Stress in Work Environment }}$}

Many authors have detailed the costs of stress in the work environment (McLean, 1974; Gmelch, 1977; Swent and Gmelch, 1977; Gherman, 1981; Greenwood and Greenwood, 1979). Monetary figures have been placed upon the decrease in the productive capacity of workers resulting from stress. Swent and Gmelch (1977) reported figures from the U. S. National Clearing. House for Mental Health Information for costs associated with inefficiency on the job, below capacity employment and excessive absenteeism. According to Swent and Gmelch (1977), stress contributed to a $\$ 17$ billion decrease in worker productivity, $\$ 5.5$ billion loss from excessive absenteeism, $\$ 2.7$ billion in costs associated with excessive unemployment, $\$ 1.9$ billion lost due to inefficiency on the job, and $\$ 1.9$ billion lost due to below capacity employment (p. 3). Therefore, the cost of stress for just the aforementioned factors amounted to a staggering $\$ 29$ billion.

Reproduced with permission of the copyright owner. Further reproduction prohibited without permission. 
However, the $\$ 29$ billion figure does not include costs associated with coronary heart disease, early deaths, psychosomatic ailments or other physical problems generated by stress. Greenwood and Greenwood (1979) cited relevant statistics of the cost of stress in categories such as work loss, hospitalization expenses, executive mortality, Workmen's Compensation costs and industrial and commercial failures. Additional1y, Greenwood and Greenwood (1979) supplemented a list of the tangible and intangible costs of employee turnover suggested by Peskin (1973) to include costs associated,with recruiting and employment expenses, breaking-in costs of the new employee, separation expense of the employee who is leaving the organization, Social Security tax payments that are front-end loaded, unemployment insurance contributions, costs associated with the demoralization of current employees and new employee ineffectiveness. Therefore, stress in the work environment has a three-fold effect in terms of human, social and economic costs.

Stress and the Individual

Individuals respond differently to stressors. Some people are more capable of handing stress than others. Gherman (1981) referred to the personality theories of Meyer Friedman and Ray Rosenman who classified individual personalities as Type A or Type B. According to Gherman (1981), Type A personalities possess "intensive drive and

Reproduced with permission of the copyright owner. Further reproduction prohibited without permission. 
ambition, aggressiveness, competiveness, a need to get things done and meet deadlines, visible restlessness, and impatience" (p. 4). The Type A person is more prone to develop heart disease as one reaction to stress.

Persson and Sjoberg (1978) reported that the value system of an individual is involved during periods of stress, as well as one's personality traits, such as extroversion versus introversion, and high versus low reactivity to situations. Values influence an individual's appraisal and evaluation of the personal impact of a situation. Depending upon one's values, one might rate any particular situation as good or bad, a challenge or a threat, something to approach or avoid. Also, anxious people are more susceptible to stress, due to the tendency to perceive more malevolence in 1ife. Similarly, introverted individuals tend to be more chronically aroused. Persson and Sjoberg (1978) summarized the difference between introverted and extroverted individuals as follows.

Introverts tend, in a cybernetic sense, to be self driving and make. the best of their powers if not driven hard. Extraverts (sic), on the contrary, seem actively to seek stimulation, to become optimally aroused. (p. $7: 42$ )

Characteristics of an individual, then, affect the reaction to and perception of stressors. Cooper (1981) summarized this thought in reporting that some people are more characterologically predisposed to stress, unable to cope or adapt to stress-provoking situations. Personality and motivation

Reproduced with permission of the copyright owner. Further reproduction prohibited without permission. 
were key factors contributing to an individual's coping ability and style, according to Cooper (1981).

\section{Summary of Stress Literature}

The review of literature relating to stress dealt with definitions of stress and a discussion of stressors, in general and for executives and school administrators in particular. Also, included was information about the effects of stress in the work environment.

The topic of stress has appeared in very early writings, although formal research in the field of stress did not begin until the 1930 s when Hans Selye published his first paper on the subject of stress in 1936.

Stress has been defined in various ways. The concept encompasses both distress and eustress, indicating it may be viewed as a danger or an opportunity. Stress refers to the response of an individual to any demand or threat. Stressors are the many things that cause an individual to be stressed. They can be divided into internal and external stressors.

Job stress is a particular form of stress, resulting from factors in the work environment. Executives are prone to stress due to the particular nature of their jobs, including the power factor, responsibility for others and the necessity for risk taking. The job of a school administrator demands an unrelenting pace, brevity of

Reproduced with permission of the copyright owner. Further reproduction prohibited without permission. 
contact with individuals and interrupted tasks. A school administrator does not have close control over his or her time and needs to respond to various rules and regulations imposed by outside agencies.

The costs of stress in the work environment have been estimated to be quite high. Stress in the work environment is associated with inefficiency on the job and low productivity. Additionally, stress costs include those associated with excessive absenteeism, below capacity employment, recruiting and employment expenses, breaking-in costs of the new employee, and separation expense of the employee who is leaving the organization.

Personality factors have a key role in stress. Type A versus Type B personalities respond differently to stress, as do introverted personalities versus extroverted personalities. Type A individuals are more likely to develop heart disease as one reaction to stress.

Additionally, one's value system is involved during stressful times, affecting whether individuals perceive given stimuli as stressful, a challenge or a threat, or something to approach or avoid. Some individuals have been found to be more characterologically predisposed to stress, incapable of adequately coping or adapting to stressprovoking situations. Personality and motivation were found to be key factors contributing to an individual's coping ability and style.

Reproduced with permission of the copyright owner. Further reproduction prohibited without permission. 
Burnout

In addition to the previously indicated effects of stress, stress has been reported to be a major cause of burnout, according to various researchers (Maslach, 1976; Freudenberger and Richelson, 1980; Veninga and Spradley, 1981). The topic of burnout has appeared in both popular and academic literature. Wax (1983, p. 2) developed the following table to reflect the breadth and frequency of the interest in burnout in popular publications.

Table IV

POPULAR PUBLICATIONS WITH ARTICLES ON BURNOUT: $1980-1982$

April 1980

June 1980

January 1981

April 1981

April 1981

May/June 1981

Ju1y 1981

August 1981

September 1981

December 1981

April 1982

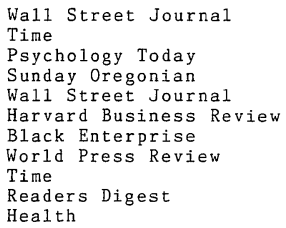

Wa11 Street Journal

Time

Psychology Today

Sunday Oregonian

Wall Street Journal

Harvard Business Review

Black Enterprise

World Press Review

Time

Readers Digest

Health

In view of the popularity of the topic of burnout, one can understand why Morrow (1981) wrote, "Today, burnout is verging on a trend" (p. 84). Freudenberger and Richelson (1980) almost complimented the type of individuals who are prone to burnout in writing

Burnout is pretty much limited to dynamic, charismatic, goal-oriented men and women or to determined idealists who want their marriages to be

Reproduced with permission of the copyright owner. Further reproduction prohibited without permission. 
the best, their work records to be outstanding, their children to shine, their community to be better. ( $p$. 28)

Norman (1981) stated this idea in similar terms. "The syndrome most frequently affects those people who have a compulsive need to be the best and the brightest" ( $p$. 46). These people might be characterized as Type A, previously described in the section dealing with stress.

Although Freudenberger (1974, 1975) was the first to describe individuals as burned-out, the first systematized attempts to define the social and psychological dimensions of the burnout syndrome were conducted by Maslach and colleagues (Maslach, 1976, 1978, 1979; Maslach and Jackson, 1978, 1979, 1981; Maslach and Pines, 1977; Pines and Maslach, 1978). This research focused upon social workers, psychologists, psychiatrists, poverty lawyers, prison guards, police officers and child-care workers. The phenomenon of burnout has been mentioned in the field of education, also, chiefly in reference to teacher burnout. Ricken (1980) wrote, "Social scientists are rushing to examine the 'living death' of today's teachers" (p. 21). Morrow (1981) wrote, "Burnout runs through the teaching profession like Asian flu" (p. 84). Additionally, Morrow (1981) reported in 1979 that Willard McGuire, president of the National Education Association, said "burnout among teachers 'threatens to reach hurricane force if it isn't checked soon'" (p. 84).

Reproduced with permission of the copyright owner. Further reproduction prohibited without permission. 
Wax (1983) is a pioneer in the research on the burnout of school administrators. Although Gmelch and Swent (1977) and Gmelch (1977) reported administrative stress factors, no other studies have focused exclusively on school administrators. In order to clarify the concept of burnout, the following review of literature will define burnout, indicate symptoms associated with burnout, describe the effects of burnout, and indicate possible contributing factors to the development of burnout.

\section{Definitions of Burnout}

The topic of burnout has become quite popular in the literature, as reflected by Table IV. This popularity has resulted in various uses of the term. Morrow (1981) commented that a difficulty with the use of the term burnout "is that it has become faddish and indiscriminate, an item of psychobabble, the psychic equivalent in its ubiquitousness, of jogging" (p. 84). Similarly, Wax (1983) wrote "Although much has been and is being written about burnout, definitions differ in clarity and in level of abstraction" (pp. 19-20).

In Freudenberger's (1974) early writing, he employed Webster's Unabridged Dictionary definition of burnout which was "to fail, wear out, or become exhausted by making excessive demands on energy, strength or resources" (Gove, 1961, p. 300). Maslach and Pines (1977) described burnout as a process involving a loss of concern for the people with

Reproduced with permission of the copyright owner. Further reproduction prohibited without permission. 
whom one is working, including a physical and emotional exhaustion, resulting in cynical and dehumanized perceptions of one's clients or patients and a loss of feeling and concern for the clients. In 1978, Pines and Maslach inciuded in their definition of burnout the development of negative job attitudes, and a negative self concept.

Kahn (1978) defined burnout as

a syndrome of inappropriate attitudes towards clients and towards self, often associated with uncomfortable physical and emotional symptoms ranging from exhaustion and insomnia to migraine and ulcer. Deterioration of performance is a frequent additional element in the syndrome. (p. 61)

Gentile and McMillan (1980) defined burnout as a "debilitating psychological condition resulting from disgruntled employment experiences which foster low employee morale and productivity" (p. 332). Veniga and Spradley (1981) described burnout as "a debilitating psychelagical condition brought about by unrelieved work stress" (p. 109). Ricken (1980) simplified the concept of burnout to be a condition "when a person is attempting to perform a job by merely going through the motions" ( $\mathrm{p}, 21$ ). Burnout, then, is a destructive, painful condition for an individual and has serious implications for worker productivity.

\section{Symptoms Associated with Burnout}

There has been generated a fairly extensive list of symptoms associated with burnout, although Mattingly (1977) cautioned "The person who is burning out out cannot be 
identified by checking off a list of symptoms or behaviors and tabulating a burn-out score", since burnout is more of a subtle pattern of symptoms unique to each individual ( $p$. 131). Maslach and Jackson (1981) reinforce the concept that it is more appropriate to assess the degree to which a person is experiencing the feelings associated with the aspects of burnout than to focus on classifying individuals as either "burned-out" or "not burned-out." Freudenberger (1977) listed symptoms of burnout as "cynicism and negativism and a tendency to be inflexible and almost rigid in thinking, which often leads to a closed mind about change or innovation" ( physical signs of burnout.

There is a feeling of exhaustion and fatigue; being unable to shake a cold, feeling physically run down; suffering from frequent headaches and gastrointestinal disturbances; this may be accompanied by a loss of weight, sleeplessness, depression, and shortness of breath. ( $p .74$ )

Later, Freudenberger (1977) named other behaviors associated with individuals who are burned-out. Burned-out individuals have a tendency to have a closed mind about change or innovation, due to the inflexible, rigid thinking that begins to develop. Also, the person may behave as a "know-it-all," displaying a superior attitude that may border on the condescending. In terms of peer interactions, the burned-out individual may either withdraw from peer interaction; or the person may go to the other extreme of socializing to such an extent that no work is accomplished.

Reproduced with permission of the copyright owner. Further reproduction prohibited without permission. 
Maslach and Pines (1979) reported that burnout is correlated with such negative indexes of personal stress as alcoholism, marital conflicts and mental illness. In 1981, Maslach and Jackson expanded this list of indices of personal stress to include physical exhaustion, insomnia, increased use of drugs and family problems. Additionally, Levinson (1981) identified the following characteristics associated with people suffering from burnout.

1. chronic fatigue

2. anger at those making demands

3. self-criticism for putting up with the demands

4. cynicism, negativism, and irritability

5. a sense of being besieged

6. hair-trigger display of emotions ( $p .76$ )

\section{Effects of Burnout}

There are other effects of burnout in addition to the previously mentioned symptoms of burnout. Maslach and Pines (1979) reported that burnout "appears to be a major factor in low worker morale, poor performance, absenteeism, and high job turnover" (p. 247). Earlier, in 1978, Maslach had stated that reports of burnout were highly correlated with job turnover.

Veninga and Spradley (1981) commented on the direct link between job burnout and the decline in American worker productivity. They reported Bureau of Labor statistics for 1980 reflecting a loss of 3.3 percent of work hours through absenteeism. Additionally, Veninga and Spradley (1981) stated that there are estimates that one out of every three 
workers who has called in sick on any particular day did so because of a stress-related problem. When job burnout sets in, workers take longer coffee breaks, take longer to accomplish tasks, make more mistakes and put off work that requires immediate attention. Additionally, Chance (1981) reported that burned-out individuals become clockwatchers and work dodgers. As a final response to burnout, many individuals choose to quit their jobs. The turnover cost to organizations due to burnout has been estimated to exceed $\$ 3.5$ billion, according to Chance (1981).

It is evident, then, that burnout is physically and emotionally costly to individuals and can hurt an organization in terms of costs associated with lower productivity, higher absenteeism, and costs associated wich higher turnover rates of employees. Additionally, all these detrimental effects of burnout do not escape affecting the clients who are to be served by the organization, since burned-out individuals tend to react to clients by withdrawing, distancing and depersonalizing. Service to the client, then, definitely is impaired. Gann (1979) summarized the detrimental effects of burnout, drawing upon the writings of Austin, Babcock, Eddy, Flagler, Ford, McNally, Thomson, Vanden Berg, and Reid (1977), Freudenberger (1975), Maslach (1978) and Pines and Maslach (1978), "The extent to which helping professionals successfully cope with the demands and psychological strains of their occupations affects directly

Reproduced with permission of the copyright owner. Further reproduction prohibited without permission. 
the quality and the quantity of services they can provide".

Burnout and the Individual

As was stated previously, certain individuals may be more prone to burnout than others. Freudenberger (1974) said the individuals who are prone to burnout are "the dedicated and the committed" (p. 161). Those individuals who value achievement and are goal-oriented idealists tend to be more prone to burnout. As Norman (1981) commented, the desire to get more from a job than just a paycheck, originating with the "me generation," has contributed to the rise in burnout. Additional1y, Levinson (1981) reported on a 20-year study of a group of middle managers who exhibited signs commonly associated with burnout. Personality tests of these middle managers indicated

They had a higher need to do a job well for its own sake than did most of their peers, and they initially had a greater need for advancement... They showed more motivation to dominate and lead and less to defer to authority than other managers. (p. 76)

Freudenberger (1975) also stated that a burnout-prone individual is one who is athoritarian and overextends out of the need to be in control.

Pines, Aronson and Kafry (1981) wrote that a special characteristic of professionals in the helping professions is dominant wish to help and work with people. Generally, those in the helping professions make statements such as "I like people. I am a people's kind of person," and "A11 my 
life I wanted to work with people." However, these helping professionals who are particularly sensitive toward others are more prone to burnout. Additionally, Pines, Aronson and Kafry (1981) commented the "client-centered" orientation that focuses on the people receiving the service, defines a professional's role of help by the clients' needs and justifies the professional's role only as long as he continues to serve" (p. 53) is another antecedent of burnout. Certainly, this client-centered orientation can be applied to a school administrator's role, also.

Cherniss (1978) reported that other possible causes of burnout among public sector helping professionals include lofty social-change goals, poor coping skills and resources, and low self esteem. Gann (1979) reported that an individual's ego development was related to burnout in that workers in higher stages of ego development more highly valued internal rewards, such as a sense of accomplishment and fulfiling work activities.

Summary of Burnout Literature

The review of 1 iterature relevant to burnout included definitions of burnout and symptoms associated with and effects of burnout, as well as individual characteristics that are associated with burnout. Burnout tends to appear in dedicated, hard-driving, goal-oriented individuals who have a drive to succeed. One's personality and value system are related to the phenomenon of burnout.

Reproduced with permission of the copyright owner. Further reproduction prohibited without permission. 
The topic of burnout is very popular in the literature, and the phenomenon of burnout has been examined in many different professions.

The major cause of burnout is stress. It is a personally destructive syndrome, costly to organizations and detrimental to the individuals served by burned-out professionals. Some symptoms associated with burnout include physical and emotional exhaustion and physical illness.

Related Factors with Stress, Burnout and Work Values

The research regarding stress, burnout and work values indicated there are some related factors. The research on stress and burnout reflected that individuals respond differently to stressors, resulting in some people being more capable of handling stress than others. Specifically, one's personality type and value system are related to an individual's coping style and ability to cope with stress, and they are related to one's susceptibility to burnout.

Research has indicated that individuals who have a compulsive need to be the best and the brightest tend to be more prone to burnout. Therefore, an individual who places a high value on prestige, or for work that will bring recognition, may be more prone to burnout.

Likewise, the values of task satisfaction and selfrealization may be more important to individuals who are more prone to burnout. The research has indicated that

Reproduced with permission of the copyright owner. Further reproduction prohibited without permission. 
individuals who desire to realize more than just a paycheck from a job, are determined idealists and have a higher need to do the job well for its own sake are more prone to burnout, a1so.

The value for control also may be related to individuals more prone to burnout, as reflected by the research of Levinson (1981) and Freudenberger (1975). More authoritarian individuals and those individuals desiring to dominate and lead rather than to defer to the authority of others have been shown to be more prone to burn out.

If one associates the value for solitude with introversion, then that value also may be related to burnout, as the research indicated that individuals who are more introverted tend to be more chronically aroused and tend to deal with stressors less effectively. Solitude itself may be related to burnout, also, since individuals experiencing burnout tend to distance themselves from others, withdrawing from personal interactions.

Finally, the value of altruism may be related to burnout. Individuals who are more people-oriented, who desire to be involved with other people in helping, supportive or service roles and who are particularly sensitive toward others have been found to be more prone to burnout.

The literature has suggested that an individual's work values may be related to burnout. Research suggested that there may be relationships between the values of Prestige,

Reproduced with permission of the copyright owner. Further reproduction prohibited without permission. 
Self-realization, Task Satisfaction, Control, Solitude and Altruism and individuals who have been found to be more prone to burnout. Values have been found to be important determinants of the stimuli to which an individual pays attention and one's value system is employed during periods of stress. 


\section{CHAPTER III}

\section{GENERAL METHODOLOGICAL DESIGN}

Two sets of data were gathered from administrators from ten school districts in Oregon and Washington. Eight of the school districts were classified as suburban districts, and two districts were classified as urban districts. In order to explore the relation between administrator work values and role perceptions associated with burnout, one set of data was collected by using the Ohio Work Values Inventory, an instrument measuring work values, and by using the Administrator Role Perception Inventory, an instrument measuring administrator role perceptions associated with burnout. The other set of data was collected from a biographical. questionnaire. The data for these instruments were analyzed to determine administrator work values and administrator role perceptions associated with burnout. Also, the data were analyzed to determine the relationships among the administrators' work values, role perceptions and selected biographical characteristics, the relationship between the sex of the administrators and their work values and role perceptions associated with burnout and the relationship between the level of administration and the administrators' work values and role perceptions associated with burnout. This 
chapter describes the design of the investigation, design of the investigation, instrumentation, data gathering procedures and the statistical design of the study.

\section{Design of the Investigation}

The research design was descriptive rather than experimental, because none of the variables of burnout, its causes, nor work values were manipulated, as would be done in a traditional experimental study. The research design for this study involved those factors that appeared to be related to, or influence, burnout in public school administrators. Cluster sampling by district was used; i.e., all administrators within each of the ten participating school districts comprised the initial sample. The districts in the sample were chosen on the basis of size, geographical location, administrative titles and willingness to participate in the research. The Spring of 1983 was chosen as the time to disseminate questionnaires in order to sample the respondents during a time of the year when administrators may be feeling the most stress and burnout. The previous administration of the Administrator Role rerception Inventory, the instrument measuring burnout, was during a period of time of low stress. These data would provide some possible comparisons on stress levels at a different time of year from the previous research. Data collection packets containing the Ohio Work Values Inventory, the Administrator

Reproduced with permission of the copyright owner. Further reproduction prohibited without permission. 
Role Perception Inventory and a biographical questionnaire were sent by the school districts to respondents on the basis of their job titles as identified by the school district's staff directory, in consultation with the district's Evaluation Department, Assistant Superintendent or designated personnel. Examples of job titles included in the sample were assistant superintendents and superintendents, directors, administrators, supervisors, principals and viceprincipals.

The independent variables of the study were level of administration and the biographical descriptors of sex, age, education, administrative work experience and years of administrative experience at the same job and at the same location. The dependent variables were: the seven constructs of the Administrator Role Perception Inventory (Psycho-physical State, Relationships, Motivation, Accomplishment, Expectation, Time and Total ARPI) and the eleven constructs of the Ohio Work Values Inventory (Altruism, Self-realization, object Orientation, Security, Control, Independence, Money, Prestige, Task Satisfaction, Solitude and Ideas/Data Orientation).

\section{Instrumentation}

The Ohio Work Values Inventory (OWVI) assesses the importance individuals attach to those qualities of work that are personally rewarding and fulfilling. This instru-

Reproduced with permission of the copyright owner. Further reproduction prohibited without permission. 
ment is one of the more inclusive of work values inventories, since it measures a total of 11 work values. The Ohio Work Values Inventory has been employed to investigate the work values of practicing nurses as compared to the work values of nurses in training (Hales, 1977), to relate work values to the sex and social class of the respondent (Hales and Fenner, 1973), life values (Fenner and Hales, 1973), grade level (Hales and Fenner, 1972) and self concepts (Hales and Yackee, 1974). The most recently completed research utilizing the OWVI was a study of the work values of secondary school teachers in Oregon (Klampe, 1983).

The Ohio Work Values Inventory consists of 77 items that measure 11 significant work values. Each of the 77 items is designed to have a logical relationship with only one of the eleven work values. The respondent assesses his or her intensity of valuing to each item by selecting one of five possible answers that represent points on a continum of "liking." The possible answers from which the respondent is to select are: Not much, A little, Fairly much, A lot, and Very much. Coefficient Alpha for each scale of the Ohio Work Values Inventory is presented in Table V (Hales and Fenner, 1973, p. 28).

Reproduced with permission of the copyright owner. Further reproduction prohibited without permission. 
TABLE $V$

COEFFICIENT ALPHA FOR EACH OWVI SCALE

Scale

Coefficient Alpha

A1truism

Object Orientation

.93

.90

.87

Security

.91

Control

.82

Self-realization

.85

Money

Task Satisfaction

.93

.78

Solitude

.85

Ideas/Data

.87

Prestige

.90

Table VI (Hales and Fenner, 1973, p. 30) provides the coefficient of correlation for each scale with each other scale of the OWVI.

TABLE VI

OWVI SCALE INTERCORRELATIONS

\begin{tabular}{|c|c|c|c|c|c|c|c|c|c|c|}
\hline Scale & objo & $\mathrm{Sec}$ & Con & $\mathrm{SR}$ & Ind & Mon & TS & Sol & $I / D$ & Pres \\
\hline $\begin{array}{l}\text { Altruism } \\
\text { Obj. Orient. } \\
\text { Security } \\
\text { Control } \\
\text { Self-realizat } \\
\text { Independence } \\
\text { Money } \\
\text { Task Satisfac } \\
\text { Solitude } \\
\text { Ideas/Data }\end{array}$ & $\begin{array}{l}.13 \\
\text { tion } \\
\text { ction }\end{array}$ & $\begin{array}{l}.14 \\
.14\end{array}$ & $\begin{array}{r}.09 \\
.18 \\
.22\end{array}$ & $\begin{array}{l}.28 \\
.13 \\
.31 \\
.06\end{array}$ & $\begin{array}{r}-.01 \\
-.03 \\
.32 \\
.28 \\
.11\end{array}$ & $\begin{array}{l}.03 \\
.08 \\
.29 \\
.36 \\
.17 \\
.37\end{array}$ & $\begin{array}{l}.12 \\
.02 \\
.37 \\
.03 \\
.46 \\
.26 \\
.17\end{array}$ & $\begin{array}{r}-.18 \\
.17 \\
.06 \\
-.12 \\
-.03 \\
.18 \\
-.03 \\
.04\end{array}$ & $\begin{array}{r}.30 \\
.14 \\
.05 \\
.00 \\
.30 \\
.07 \\
-.07 \\
.12 \\
.15\end{array}$ & $\begin{array}{r}.30 \\
.04 \\
.14 \\
.33 \\
.25 \\
.18 \\
.45 \\
.17 \\
-.14 \\
.19\end{array}$ \\
\hline
\end{tabular}

Reproduced with permission of the copyright owner. Further reproduction prohibited without permission. 
The Administrator Role Perception Inventory is the only instrument designed specifically for use with school administrators as a means of measuring variables associated with burnout. Other instruments have been constructed and used to measure burnout in populations other than school administrators. These other instruments have been used in the research of Freudenberger (1980), Leeson (1980), Garcia (1981), and Maslach and Jackson (1981). However, information concerning the development, testing, reliability and validity of these instruments was not published, except for the Maslach Burnout Inventory. In contrast, the Administrator Role Perception Inventory (ARPI) was designed specifically for use with school administrators. Additionally, the reliability of the ARPI and its scales, scale intercorrelations, and validity factors have been investigated.

The Administrator Role Perception Inventory consists of 50 statements. The respondent assesses his or her intensity of agreement to each statement by selecting one of five possible answers. These response options represent points on a continuum of "agreement." They are: Strongly Disagree, Disagree, Neutra1, Agree, Strong1y Agree. The 50 items in the ARPI belong to five subscales associated with burnout. These subscales are: Psycho-physical State, Relationship, Motivation, Accomplishment and Expectation. A Time subscale, composed of selected items from the other

Reproduced with permission of the copyright owner. Further reproduction prohibited without permission. 
scales, and a. Total ARPI scale measuring burnout also is included. Coefficient Alpha for each subscale and for the Total Administrator Role Perception Inventory is presented in Table VII (Wax, 1983, p. 85).

TABLE VII

COEFFICIENT ALPHA FOR EACH SUBSCALE

AND FOR TOTAL ARPI

\begin{tabular}{lc}
\hline \multicolumn{1}{c}{ Subscale } & Coefficient Alpha \\
\hline Expectation & .71 \\
Psycho-physical State & .85 \\
Relationships & .75 \\
Moitivation & .70 \\
Accomplishment & .78 \\
Time & .78 \\
Total ARPI scale & .91 \\
\hline
\end{tabular}

Table VIII (Wax, 1983, p. 87) provides the coefficients of correlation for each of the five subscales with each of the other subscales for the ARPI. Additionally, Table VIII depicts the relationships of these subscales with the Time and Total scales; these intercorrelations are higher, since both Time and Total are composite scales. Table LXIX in Appendix E presents the means and standard deviations from previous research (Wax, 1983) using the ARPI.

Reproduced with permission of the copyright owner. Further reproduction prohibited without permission. 
TABLE VIII

ARPI SCALE INTERCORRELATIONS

\begin{tabular}{|c|c|c|c|c|c|c|c|}
\hline & Exp & Mot & P S & $\operatorname{Re} 1$ & $A C C$ & Tim & Tot ARPI \\
\hline Expectation & & .35 & .56 & .31 & .34 & .50 & .70 \\
\hline Motivation & & & .58 & .46 & .63 & .66 & .78 \\
\hline $\begin{array}{l}\text { Psycho-physica } 1 \\
\text { State }\end{array}$ & & & & .46 & .51 & .80 & .85 \\
\hline Relationships & & & & & .58 & .67 & .70 \\
\hline Accomplishment. & & & & & & .66 & .77 \\
\hline Time & & & & & & & .86 \\
\hline
\end{tabular}

Data Gathering Procedures

Data gathering procedures were finalized in conjunction with each participating school district to allow for a minimum of disruption in the district, school and classroom operations. Seven districts distributed the questionnaires through their intradistrict mail system, including a letter of endorsement and support of the district's superintendent for the research. Three school districts disseminated the questionnaires during an administrative team meeting. The researcher was asked to explain the research personally at two of those three district team meetings. All questionnaires were completed during the Spring of 1983. Respondents were asked to return the questionnaires. within one week of receipt of the questionnaires in a sealed, pre- 
addressed envelope. The researcher was contacted by eight districts to pick up the questionnaires when it appeared, by count, as though. the majority of questionnaires had been returned. In one district, each administrator mailed the questionnaire directly to the researcher's home address. One district's Evaluation Department mailed the total batch of questionnaires to the researcher's home address after the majority had been received, rather than the researcher personally picking up the questionnaires, as was done in eight of the school districts. There were no follow-up procedures with those individuals who did not complete the questionnaires initially in any of the ten participating school districts. The school districts and all respondents were assured that confidentiality of the district and of individual respondents would be maintained.

\section{$\underline{\text { Statistical }}$ Design}

The means and standard deviations of the responses of the total sample on the Administrator Role Perception Inventory and the Ohio Work Values Inventory were computed and are displayed in tables. Also, the means and standard deviations were computed and are displayed for the following subsets of the sample: superintendents; elementary principals and vice-principals; middle-school/junior high principals and vice-principals; secondary principals and viceprincipals; and other central office line and staff adminis-

Reproduced with permission of the copyright owner. Further reproduction prohibited without permission. 
trators. The responses to each instrument were analyzed separately by sex of the respondent and within level of administration, using multivariate analyses of variance, with alpha set at.05, for each analysis, followed by univariate analyses of variance and Scheffé tests, as appropriate. A factor analysis, using oblimin rotation, was performed on the responses of the OWVI in examining the internal construct validity. Finally, correlational matrices of the scales of the ARPI and OWVI were computed in order to investigate the relationship between specific scales on the ARPI with scales on the OWVI and between specific scales on the ARPI and OWVI with selected biographical data.

\section{$\underline{\text { Summary }}$}

The research sample included ten school districts in Oregon and Washington, classified as urban or suburban. Respondents completed the Ohio Work Values Inventory, an instrument measuring their work values, and the Administrator Role Perception Inventory, an instrument measuring role perceptions associated with burnout, and a biographical data sheet.

The research design was descriptive, since no variables were manipulated. The independent variables of the study were level of administration and the biographical data collected. The dependent variables were the constructs of the Administrator Role Perception Inventory and the 
constructs of the Ohio Work Values Inventory.

Coefficient Alpha and scale intercorrelations are presented for the Administrator Role Perception Inventory and the Ohio Work Values Inventory.

Data gathering procedures included disseminating the questionnaires either in an administrative team meeting or through the districts' intradistrict mail system.

The statistical design included computing the means and standard deviations of the responses of the total sample on the Administrator Role Perception Inventory and the Ohio Work Values Inventory. Also, the means and standard deviations were computed for specified sample subsets. Multivariate analyses of variance were performed, with alpha set at .05, followed by univariate analyses of variance and Scheffé tests, as appropriate, to determine the relationship between the administrators' sex and their work values and role perceptions associated with burnout and between the level of administration and the administrators' work values and role perceptions associated with burnout. Additionally, a factor analysis, using oblimin rotation, was conducted to investigate the internal validity of the OWVI.

Reproduced with permission of the copyright owner. Further reproduction prohibited without permission. 
CHAPTER IV

PRESENTATION OF THE FINDINGS

This chapter presents the results of the research investigating the relationship between public school administrator work values, as measured by the Ohio Work Values Inventory, and role perceptions associated with burnout, as measured by the Administrator Role Perception Inventory. Sample characteristics, scoring procedures, and reliability and validity data also are reported.

\section{$\underline{\text { Sample }}$}

The sample is described in terms of its size, age and sex of the participants, their administrative positions, whether their position is line, staff or both, their job locations, the number of years they have been in their present position, the number of years of public school administration, their educational level and certificates held.

$\underline{\text { Size }}$

All 701 administrators of ten school districts in Oregon and Washington were included in the study. Those 701 administrators included all individuals classified by their district as an administrator, including those persons in

Reproduced with permission of the copyright owner. Further reproduction prohibited without permission. 
central office positions, such as transportation manager, data processing director, etc. Districts classified as suburban reported 263 personnel in administrative positions. All 263 individuals were given questionnaires. Urban districts included 438 individuals receiving questionnaires. A total of 388 returns were received, or about $55 \%$ of those disseminated. Of the 388 returned questionnaires, $54 \%$ were received from suburban respondents, and $46 \%$ were returned by urban respondents. Suburban respondents returned 210 questionnaires for a suburban return rate of $80 \%$, and urban respondents returned 178 questionnaires for an urban return rate of $43 \%$. Table IX presents data relevant to classification of the sample school districts.

TABLE IX

GEOGRAPHICAL CHARACTERISTICS AND RETURN RATE

\begin{tabular}{lccc}
\hline Location & Frequency & Percent & Return Rate \\
\hline Urban & 178 & 46 & 43 \\
Suburban & 210 & 54 & 80 \\
\hline TOTAL & 388 & 100 & \\
\hline
\end{tabular}

Description

The distribution of subjects in terms of age, sex, position held, job type, job location, years in present

Reproduced with permission of the copyright owner. Further reproduction prohibited without permission. 
position, years of administrative experience and educational degree follows, identifying the pertinent statistics for each biographical descriptor.

Sex. Participants were asked to indicate their sex. The results indicated that $70.9 \%$ were males, while $27.8 \%$ were females. Table $X$ summarizes the distribution of male and female administrators.

TABLE $X$

DISTRIBUTION OF MALE/FEMALE ADMINISTRATORS

\begin{tabular}{lcc} 
& Number of Admin. & Percentage of Sample \\
\hline Male & 275 & 70.9 \\
Female & 108 & 27.8 \\
Unidentified & 5 & 1.3 \\
\hline Total & 388 & 100.0 \\
\hline
\end{tabular}

Age. The mean age in year of the 380 respondents who provided that information was 45.9 , with a range of 23 years to 66 years. The median was 46.0 , indicating the distribution was close to symmetrical. The mode, or most frequently reported age, was 43 , and the standard deviation of the age distribution was 8.3. Table XI provides a summary of the distribution of subjects by age.

Reproduced with permission of the copyright owner. Further reproduction prohibited without permission. 
TABLE XI

DISTRIBUTION OF ADMINISTRATORS BY AGE

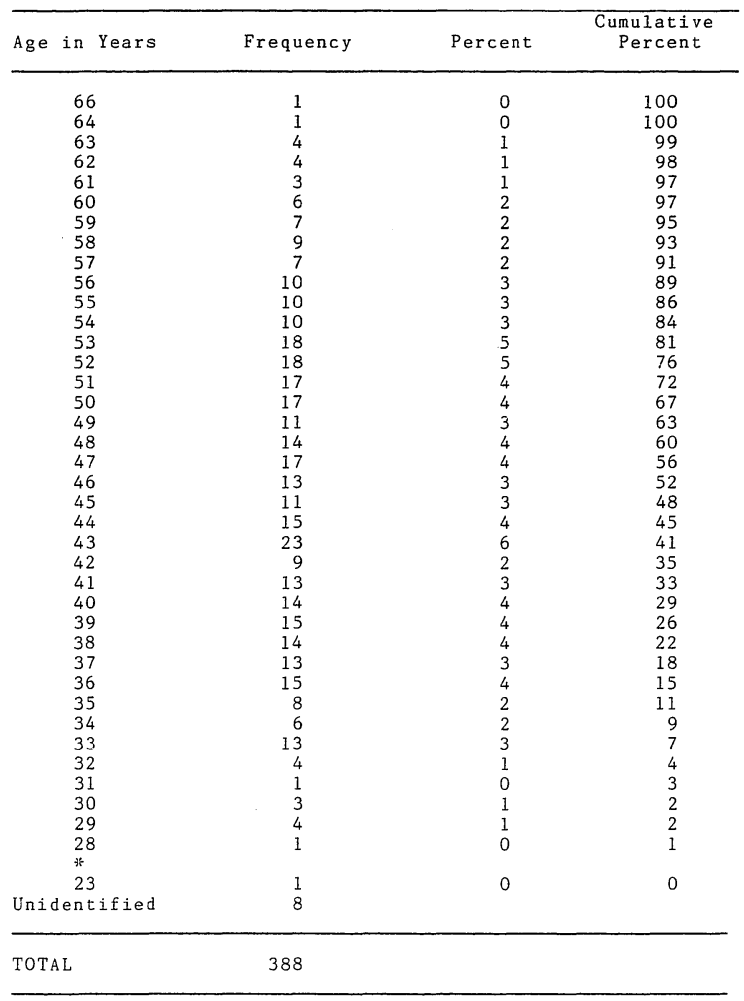

Reproduced with permission of the copyright owner. Further reproduction prohibited without permission. 
Position type. The sample was analyzed in terms of position type--line or staff. A line job was defined on the Job Data form as "a position in the direct line of authority from superintendent to principal or vice-principal, direct and specific accountability for instruction." A staff position was defined on the Job Data form as "a position whose function is to help line administrators; provides service, support, analysis." The results show that 69.8 of those responding were in line positions, while 27.8 were in staff positions. Table XII summarizes the distribution of subjects by position type.

TABLE XII

DISTRIBUTION OF ADMINISTRATORS BY POSITION TYPE

\begin{tabular}{lcc}
\hline \multicolumn{1}{c}{ Category } & Frequency & Percent \\
\hline Line & 271 & 69.8 \\
Staff & 108 & 27.8 \\
Combination Line/Staff & 8 & 2.1 \\
Unidentified & 1 & 0.3 \\
\hline TOTAL & 388 & 100.0 \\
\hline
\end{tabular}

Administrative position. A large variety of administrative postions were included in the sample. (See Table XIII.) Participants were asked to name their job title. 
TABLE XIII

DISTRIBUTION OF SUBJECTS BY ADMINISTRATIVE POSITION

\begin{tabular}{|c|c|c|}
\hline Position & Frequency & Percent \\
\hline $\begin{array}{l}\text { School District } \\
\text { Superintendent } \\
\text { Assistant Superintendent } \\
\text { Director of Curriculum/Instruction } \\
\text { Director of Counseling/Stu. Services } \\
\text { Director of Special Education } \\
\text { Director of Management Services } \\
\text { Director of Program Evaluation } \\
\text { Director of Curricular Area } \\
\text { Director of Special Programs } \\
\text { Director of Personnel } \\
\text { Director of Media } \\
\text { Director of Support Services } \\
\text { Director of Secondary Schools } \\
\text { Director of Elementary Schools } \\
\text { Other } \\
\text { Total }\end{array}$ & $\begin{array}{r}9 \\
11 \\
10 \\
3 \\
6 \\
12 \\
4 \\
11 \\
15 \\
6 \\
3 \\
18 \\
1 \\
2 \\
27 \\
138\end{array}$ & $\begin{array}{l}2 \\
3 \\
3 \\
1 \\
2 \\
3 \\
1 \\
3 \\
4 \\
2 \\
1 \\
5 \\
0 \\
1 \\
\frac{7}{38}\end{array}$ \\
\hline $\begin{array}{l}\text { High School } \\
\text { Principal } \\
\text { Vice-Principal } \\
\text { Athletic Director } \\
\text { Other } \\
\text { Total }\end{array}$ & $\begin{array}{r}16 \\
51 \\
1 \\
1 \\
69\end{array}$ & $\begin{array}{r}4 \\
14 \\
0 \\
0 \\
18\end{array}$ \\
\hline $\begin{array}{l}\text { Junior High/Middle School } \\
\text { Principal } \\
\text { Vice-Principal } \\
\text { Other } \\
\text { Total }\end{array}$ & $\begin{array}{r}30 \\
28 \\
0 \\
58\end{array}$ & $\begin{array}{r}8 \\
9 \\
0 \\
17\end{array}$ \\
\hline $\begin{array}{l}\text { Elementary School } \\
\text { Principal } \\
\text { Vice-Principal } \\
\text { Other } \\
\text { Total }\end{array}$ & $\begin{array}{r}110 \\
1 \\
1 \\
111\end{array}$ & $\begin{array}{r}29 \\
0 \\
0 \\
29\end{array}$ \\
\hline Undesignated & 11 & \\
\hline TOTAL ALL CATEGORIES & 388 & \\
\hline
\end{tabular}

Reproduced with permission of the copyright owner. Further reproduction prohibited without permission. 
Those job titles were grouped into 26 categories, 21 of which were specific and five of which were general. The job category groupings were those developed by Wax (1983). Of the 377 administrators who provided this information, approximately $63 \%$ were building principals and viceprincipals, while five percent were superintendents and assistant superintendents. A more detailed description of the distribution of subjects by job title is presented in Table XIII.

Job Location. Subjects were categorized by location of their jobs. The classification categories were: central office, elementary school, high school, middle school/junior high school. The analysis of the distribution indicated $62.8 \%$ were at the building levels of elementary, middle school/junior high school or high school, and $36.3 \%$ were classified as central office. Table XIV provides a summary of subject distribution by the location of their jobs.

TABLE XIV

DISTRIBUTION OF ADMINISTRATORS BY JOB LOCATION

\begin{tabular}{lrr}
\hline \multicolumn{1}{c}{ Location } & Frequency & Percent \\
\hline Central office & 141 & 36.3 \\
Elementary school & 113 & 29.1 \\
Junior high or middle school & 61 & 15.7 \\
Senior high school & 70 & 18.0 \\
School combination & 2 & 0.6 \\
Unidentified & 1 & 100.0 \\
\hline TOTAL & 388 & \\
\hline
\end{tabular}

Reproduced with permission of the copyright owner. Further reproduction prohibited without permission. 
Years in present position. Individuals were asked to write the number of years at their present position at the same location with the same job responsibilities, etc. The years in a position were rounded to the nearest year. TABLE XV

DISTRIBUTION OF ADMINISTRATORS BY

YEARS IN PRESENT POSITION

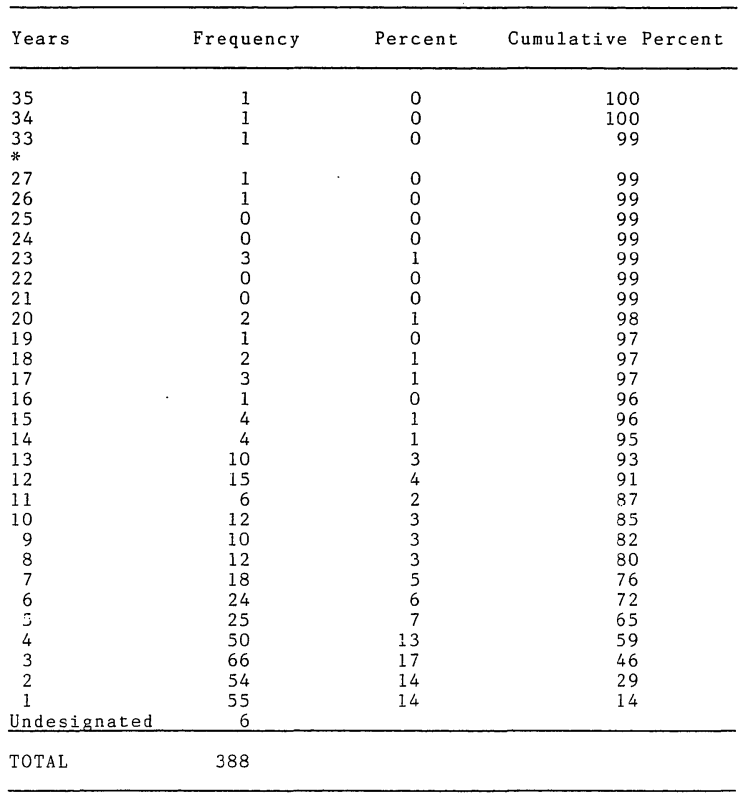

Reproduced with permission of the copyright owner. Further reproduction prohibited without permission. 
Approximately $58 \%$ of the 382 individuals responding to this question had held their present job four years or less, and $80 \%$ had been in their present postion fewer than nine years. The mean for the number of years in the same position was 5.6, and the standard deviation was 5.2. Table XV summarizes the distribution of years administrators in the sample held their current position.

Highest Degree Earned. Participants were asked to indicate the highest degree earned. These were categorized as Bachelor's, Master's or Doctorate. In the distribution summary presented in Table XVI, it is evident the largest percentage, $74.5 \%$, of administrators in the sample have earned a Master's degree.

TABLE XVI

DISTRIBUTION OF HIGHEST DEGREE EARNED

\begin{tabular}{lcc}
\hline Degree & Frequency & Percent \\
\hline Doctorate & 58 & 14.9 \\
Master's & 289 & 74.5 \\
Bachelor's & 23 & 5.9 \\
Undesignated & 18 & 4.6 \\
\hline TOTAL & 388 & 100.0 \\
\hline
\end{tabular}

Reproduced with permission of the copyright owner. Further reproduction prohibited without permission. 
Years of work experience as educational administrator. Additionally, subjects were asked to indicate the cumulative number of years of having a position as an educational administrator. Approximately 50\% had been an educational administrator for 10 years or less. The mean for the group was 11.7. Table XVII summarizes the distribution of years of being an educational administrator.

TABI:E XVII

DISTRIBUTION OF YEARS OF EDUCATIONAL ADMINISTRATOR

\begin{tabular}{cccc}
\hline & Frequency & Percent & $\begin{array}{c}\text { Cumulative } \\
\text { Percent }\end{array}$ \\
\hline $40-42$ & 1 & 0 & 100 \\
$37-39$ & 1 & 0 & 100 \\
$34-36$ & 1 & 0 & 99 \\
$31-33$ & 3 & 0 & 99 \\
$28-30$ & 8 & 3 & 98 \\
$25-27$ & 15 & 4 & 96 \\
$22-24$ & 15 & 4 & 89 \\
$19-21$ & 23 & 6 & 83 \\
$16-18$ & 36 & 13 & 59 \\
$13-15$ & 54 & 15 & 44 \\
$10-12$ & 60 & 15 & 128 \\
$7-9$ & 60 & 16 & \\
$4-6$ & 60 & 12 & \\
$1-3$ & 48 & & \\
Unidentified & 3 & & \\
\hline
\end{tabular}

Certificates. Individuals were asked to indicate certificates earned. These were classified as Basic Administrative, Standard Administrative, Supervisor, Personnel, 
Superintendent, or other. The results show that $52.6 \%$ of those responding possessed a Standard Administrative certificate. The second most frequently identified certificate was the Basic Administrative. Table XVIII summarizes the distribution of certificates held.

TABLE XVIII

DISTRIBUTION OF CERTIFICATES HELD

\begin{tabular}{lcc}
\hline Certificate & Frequency & Percent \\
\hline Superintendent & 24 & 6.2 \\
Supervisor & 9 & 2.3 \\
Personnel & 7 & 1.8 \\
Standard Administrative & 204 & 52.6 \\
Basic Administrative & 52 & 13.4 \\
Other & 24 & 6.2 \\
Unidentified & 68 & 17.5 \\
\hline TOTAL & 388 & 100.0 \\
\hline
\end{tabular}

Summary. The findings indicated that the sample for this research consisted primarily of line administrators with job responsibilities at the building levels of high school, middle school/junior high school or elementary school. Most of the administrators held their jobs four years or less, and the average administrator responding was a 46-year-old male with a Master's degree and a Standard Administrative certificate.

Reproduced with permission of the copyright owner. Further reproduction prohibited without permission. 
Scoring of the OWVI

The ohio Work Values Inventory (OWVI) consists of 77 items, divided equally among the 11 scales of Altruism, Self-realization, Object Orientation, Security, Control, Independence, Money, Prestige, Task Satisfaction, Solitude and Ideas/Data Orientation. Table XIX indicates the assignment of the OWVI items to the scales.

TABLE XIX

ASSIGNMENT OF OWVI ITEMS TO SCALES

Scale

A1truism

Object Orientation

Security

Control

Self-realization

Independence

Money

Task Satisfaction

Solitude

Ideas/Data Orientation

Prestige
I tems

$$
\begin{array}{lllllll}
1, & 12, & 23, & 34, & 45, & 56, & 67 \\
2, & 13, & 24, & 35, & 46, & 57, & 68 \\
3, & 14, & 25, & 36, & 47, & 58, & 69 \\
4, & 15, & 26, & 37, & 48, & 59, & 70 \\
5, & 16, & 27, & 38, & 49, & 60, & 71 \\
6, & 17, & 28, & 39, & 50, & 61, & 72 \\
7, & 18, & 29, & 40, & 51, & 62, & 73 \\
8, & 19, & 30, & 41, & 52, & 63, & 74 \\
9, & 20, & 31, & 42, & 53, & 64, & 75 \\
10, & 21, & 32, & 43, & 54, & 65, & 76 \\
11, & 22, & 33, & 44, & 55, & 66, & 77
\end{array}
$$

Respondents were asked to read each statement in the OWVI and decide how strongly they felt about the statement. 
Respondents were asked to mark an " $x$ " on the line corresponding best to their opinion. For each question, one of the following responses was asked to be chosen: Not much, A little, Fairly much, A lot, Very much. The items were scored from one to five, in the aforementioned order. Each scale is represented by seven items. Therefore, the maximum possible score on each scale is 35 , and the lowest possible score on each scale is seven. The scales were designed such that higher scores correspond with a stronger value for the work value being scored.

\section{Analysis of the Scales of the OWVI}

The descriptive statistics for the scores on the scales on the Ohio Work Values Inventory follow. First, a summary of the means and standard deviations for each scale is presented. Then, a more detailed description of the statistics for each scale is reported. There is not normative data for this instrument; therefore, the reported means are unanchored.

Summary of the Scores

The means for each scale of the OWVI ranged from 14.96 for the Solitude scale to 32.31 for the scale of Task Satisfaction. The standard deviations of the 11 scales ranged from 3.25 for the scale of Task Satisfaction to 7.29 for the scale of Money. Table XX summarizes these statistics in more detail.

Reproduced with permission of the copyright owner. Further reproduction prohibited without permission. 
TABLE XX

MEANS AND STANDARD DEVIATIONS FOR OWVI SCALES

\begin{tabular}{lll}
\hline \multicolumn{1}{c}{ Scale } & Mean & Standard Deviation \\
\hline Altruism & 29.16 & 4.76 \\
Object Orientation & 18.73 & 6.22 \\
Security & 22.20 & 7.36 \\
Control & 23.93 & 5.59 \\
Self-realization & 31.74 & 3.31 \\
Independence & 25.75 & 4.98 \\
Money & 23.38 & 7.29 \\
Task Satisfaction & 32.31 & 3.25 \\
Solitude & 14.96 & 4.94 \\
Ideas/Data Orientation & 28.81 & 4.28 \\
Prestige & 20.24 & 6.53 \\
\hline
\end{tabular}

\begin{abstract}
Altruism
The construct of Altruism signifies the importance given to the opportunity for involvement with other people in a helping, supportive or service role. A quality of interpersonal giving by the valuer characterizes the relationships that are developed in the work. A higher score on this scale indicates that the individual attaches much importance to involvement with other people in a helping, supportive or service role.
\end{abstract}

Reproduced with permission of the copyright owner. Further reproduction prohibited without permission. 
The mean score for the Altruism scale was 29.16, indicating respondents assigned considerable importance to the value of Altruism. The standard deviation was 4.76, and the median was 29.20. The mode, or most frequently occurring score was 35. Table XXI presents the score frequency distribution for the Altruism scale.

TABLE XXI

FREQUENCY DISTRIBUTION OF SCORES ON ALTRUISM

\begin{tabular}{|c|c|c|c|}
\hline Score & Frequency & Percent & $\begin{array}{c}\text { Cumulative } \\
\text { Percent }\end{array}$ \\
\hline 35 & 78 & 20 & 100 \\
\hline 34 & 23 & 6 & 80 \\
\hline 33 & 15 & 4 & 74 \\
\hline 32 & 21 & 5 & 70 \\
\hline 31 & 21 & 5 & 65 \\
\hline 30 & 27 & 7 & 59 \\
\hline 29 & 32 & 8 & 52 \\
\hline 28 & 39 & 10 & 44 \\
\hline 27 & 32 & 8 & 34 \\
\hline 26 & 21 & 5 & 26 \\
\hline 25 & 13 & 3 & 20 \\
\hline 24 & 18 & 5 & 17 \\
\hline 23 & 11 & 3 & 12 \\
\hline 22 & 10 & 3 & 10 \\
\hline 21 & 10 & 3 & 7 \\
\hline 20 & 7 & 2 & 4 \\
\hline 19 & 3 & 1 & 3 \\
\hline 18 & 3 & 1 & 2 \\
\hline 17 & 1 & 0 & 1 \\
\hline 16 & 1 & 0 & 1 \\
\hline$*$ & & & \\
\hline 11 & 1 & 0 & 1 \\
\hline 8 & 1 & 0 & 0 \\
\hline TOTAL & 388 & & \\
\hline
\end{tabular}

Reproduced with permission of the copyright owner. Further reproduction prohibited without permission. 


\section{Object Orientation}

The construct of Object Orientation expresses the valuation of handling, tending or manipulating physical objects, such as utensils, materials, tools or apparatus. The value relates to work that involves making, fixing operating or changing the appearance of things. A higher score for the object Orientation scale indicates that the individual assigns much importance to handling, tending or manipulating physical objects.

The mean score on the Object Orientation scale was 18.73, indicating respondents assigned moderate importance to this value. The standard deviation was 6.22. The median was 18.30 , and the mode was 19. Table XXII presents the score frequency distribution for the object Orientation scale.

\section{$\underline{\text { Security }}$}

The construct of Security measures the desire for work that is steady and dependable, immune to unpredictable layoff or dismissal. A high score reflects that the individual assigns much importance to possessing a steady, dependable position.

The mean of the Security scale was 22.20 , indicating respondents assigned moderate importance to this value. The standard deviation was 7.36 , and the median was 21.70 . This scale distribution was the least skewed of all 11 work value 
TABLE XXII

FREQUENCY DISTRIBUTION OF SCORES ON OBJECT ORIENTATION

\begin{tabular}{|c|c|c|c|}
\hline Score & Frequency & Percent & $\begin{array}{c}\text { Cumulative } \\
\text { Percent }\end{array}$ \\
\hline 35 & 6 & 2 & 100 \\
\hline 34 & 2 & 1 & 98 \\
\hline 33 & 1 & 0 & 98 \\
\hline 32 & 3 & 1 & 98 \\
\hline 31 & 4 & 1 & 97 \\
\hline 30 & 6 & 2 & 96 \\
\hline 29 & 5 & 1 & $\begin{array}{l}90 \\
94\end{array}$ \\
\hline 28 & 10 & 3 & 93 \\
\hline 27 & 12 & 3 & 90 \\
\hline 26 & 8 & 2 & 87 \\
\hline 25 & 11 & 3 & 85 \\
\hline 24 & 16 & 4 & 82 \\
\hline 23 & 14 & 4 & 78 \\
\hline 22 & 28 & 7 & 75 \\
\hline 21 & 14 & 4 & 68 \\
\hline 20 & 20 & 5 & 64 \\
\hline 19 & 29 & 7 & 59 \\
\hline 18 & 27 & 7 & 51 \\
\hline 17 & 25 & 6 & 44 \\
\hline 16 & 20 & 5 & 38 \\
\hline 15 & 20 & 5 & 33 \\
\hline 14 & 22 & 6 & 28 \\
\hline 13 & 19 & 5 & 22 \\
\hline 12 & 19 & 5 & 17 \\
\hline 11 & 16 & 4 & 12 \\
\hline 10 & 9 & 2 & 8 \\
\hline 9 & 9 & 2 & 6 \\
\hline 8 & 5 & 1 & 3 \\
\hline 7 & 8 & 2 & 2 \\
\hline TOTAL & 388 & & \\
\hline
\end{tabular}

scales, with a calculated value of .005 . The mode was 21. Table XXIII summarizes the score frequency distribution for the Security scale.

Reproduced with permission of the copyright owner. Further reproduction prohibited without permission. 
TABLE XXIII

FREQUENCY DISTRIBUTION OF SCORES ON SECURITY

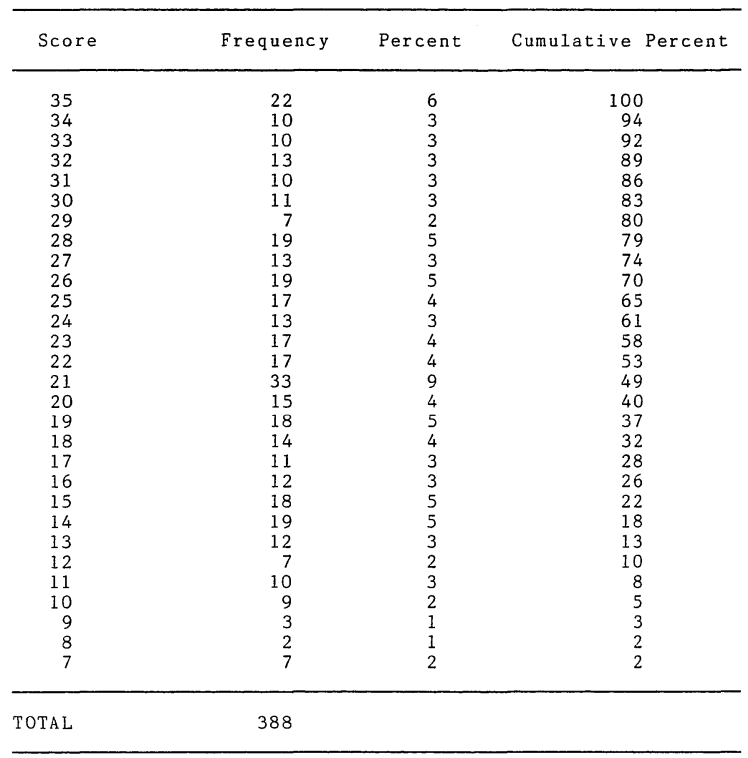

\section{Contro1}

The construct of Control indicates the importance the individual assigns to having the opportunity to take a leadership role or responsibility for other workers in the 
conduct of their work. This construct measures the value one has for a job in which the individual has an influencing or decision-making role with regard to the planning, supervision and evaluation of workers. A higher score

TABLE XXIV

FREQUENCY DISTRIBUTION OF SCORES ON CONTROL

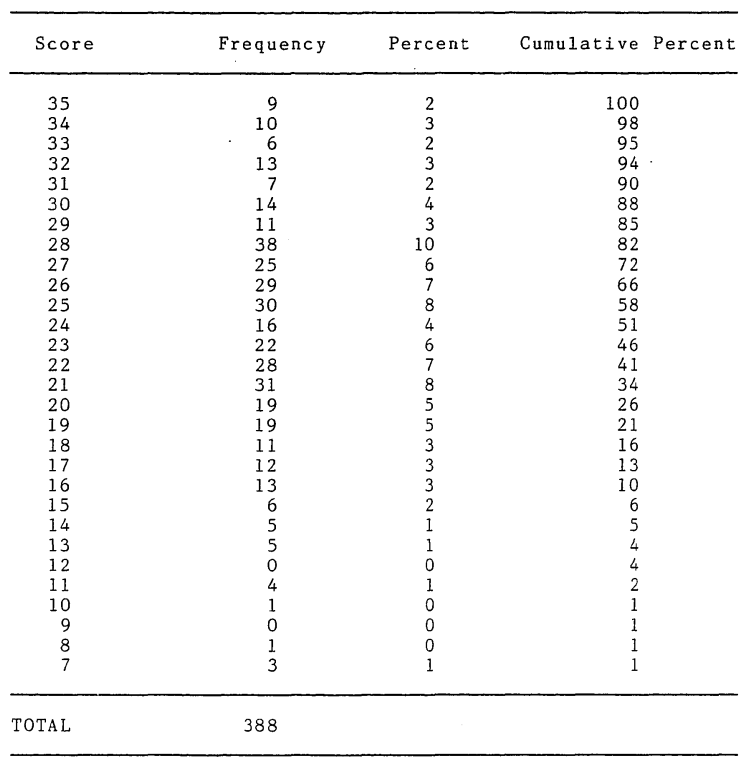

Reproduced with permission of the copyright owner. Further reproduction prohibited without permission. 
indicates that the individual wants a leadership role or responsibility for other workers.

The mean of the Control scale was 23.93, indicating respondents assigned moderate to considerable importance to the value of Control. The standard deviation was 5.59, and the median was 24.40 . The mode was 28 . Table XXIV presents the frequency distribution for the scores on the Control scale.

\section{$\underline{\text { Self-realization }}$}

The construct of Self-realization expresses a preference toward work that permits the individual to utilize one's skills, abilities or talents. The work allows for continued personal growth and realization of one's potential. A higher score indicates that the respondent wants a job that permits one to utilize one's skills, abilities or talents.

The mean on the Self-realization scale was 31.74 , indicating respondents assigned considerable to great importance to Self-realization. The standard deviation was 3.31 , and the median was 32.70 . The mode was 35 , the highest possible score for the scale. Table XXV presents the frequency distribution of the scores on the Self-realization scale.

Reproduced with permission of the copyright owner. Further reproduction prohibited without permission. 
TABLE XXV

FREQUENCY DISTRIBUTION OF SCORES ON SELF-REALIZATION

\begin{tabular}{rrrr}
\hline Score & Frequency & Percent & Cumulative Percent \\
\hline 35 & 115 & 29.6 & 100.0 \\
34 & 49 & 12.6 & 70.4 \\
33 & 39 & 10.1 & 57.7 \\
32 & 27 & 7.0 & 47.7 \\
31 & 32 & 8.2 & 40.7 \\
30 & 18 & 4.6 & 32.5 \\
29 & 26 & 6.7 & 27.8 \\
28 & 42 & 10.8 & 21.1 \\
27 & 15 & 3.9 & 10.3 \\
26 & 9 & 2.3 & 6.4 \\
25 & 5 & 1.3 & 2.8 \\
24 & 4 & 1.0 & 1.8 \\
23 & 4 & 1.0 & 0.5 \\
22 & 1 & 0.3 & 0.5 \\
21 & 0 & 0.0 & 0.3 \\
20 & 1 & 0.3 & 0.3 \\
19 & 0 & 0.0 & 0.3 \\
18 & 0 & 0.0 & \\
17 & 1 & 0.3 & \\
\hline TOTAL & 5 & 100.0 & \\
\hline
\end{tabular}

Independence

The construct of Independence signifies the importance one assigns to work allowing one to determine working conditions. A higher score on this scale indicates the individual prefers to be free from close supervision and wishes to structure the individual's own hours and working methods.

The mean on the Independence scale was 25.75 , indicating respondents assigned considerable importance to Independence in their jobs. The standard deviation was 4.98 , 
and the median was 25.99. The mode was 26. Table XXVI presents the frequency distribution for the scores on the Independence scale.

TABLE XXVI

FREQUENCY DISTRIBUTION OF SCORES ON INDEPENDENCE

\begin{tabular}{lrrr}
\hline Score & Frequency & Percent & Cumulative Percent \\
\hline 35 & 10 & 3 & \\
34 & 7 & 2 & 90 \\
33 & 20 & 5 & 96 \\
32 & 17 & 4 & 90 \\
31 & 25 & 6 & 86 \\
30 & 22 & 6 & 80 \\
29 & 13 & 3 & 74 \\
28 & 33 & 9 & 71 \\
27 & 28 & 7 & 62 \\
26 & 37 & 10 & 55 \\
25 & 27 & 7 & 45 \\
24 & 21 & 5 & 38 \\
23 & 22 & 6 & 33 \\
22 & 22 & 6 & 27 \\
21 & 21 & 5 & 16 \\
20 & 21 & 5 & 11 \\
19 & 9 & 2 & 9 \\
18 & 13 & 3 & 5 \\
17 & 10 & 3 & 3 \\
16 & 3 & 1 & 2 \\
15 & 2 & 1 & 1 \\
14 & 1 & 0 & 1 \\
13 & 1 & 0 & 1 \\
12 & 1 & 0 & 1 \\
11 & 2 & 1 & \\
\hline TOTL & & & \\
\hline
\end{tabular}

\section{Money}

The scale of Money measures the importance the individual assigns to a position that enables one to have a 
substantial income--more than enough to assure the basic needs of life. A higher score indicates the respondent values a position in which one can earn a substantial income.

TABLE XXVII

FREQUENCY DISTRIBUTION OF SCORES ON MONEY

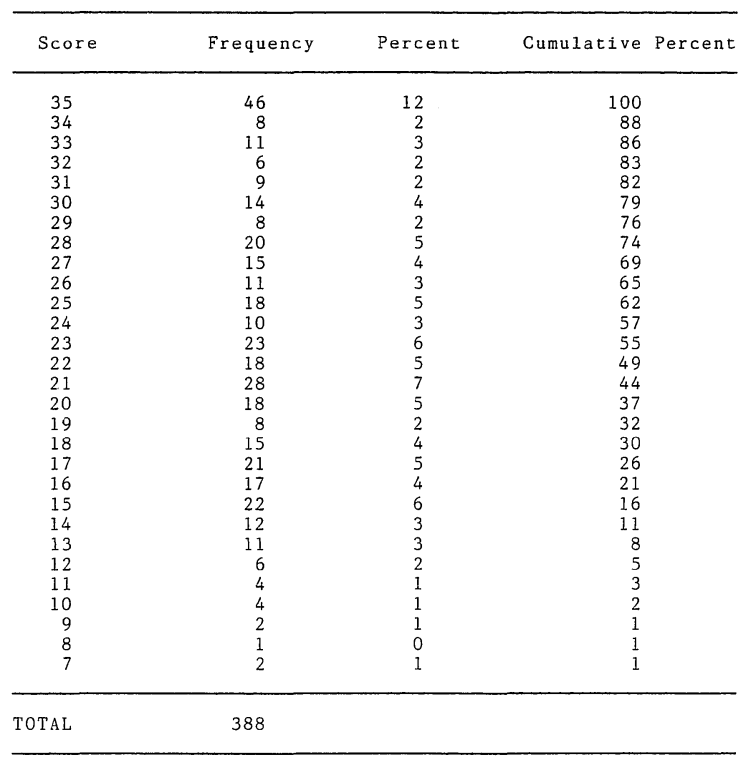

Reproduced with permission of the copyright owner. Further reproduction prohibited without permission. 
The mean score for the Money scale was 23.38, indicating respondents assigned moderate to considerable importance to this work value. The standard deviation was 7.29, and the median was 22.70. The mode was 35 , the highest score possible. The frequency distribution of scores for the Money scale is presented in Table XXVII.

\section{Task $\underline{\text { Satisfaction }}$}

The scale of Task Satisfaction measures the importance the individual assigns to work that generally is interesting and enjoyable. The individual, for the most part, performs work tasks he or she can look forward to doing. A higher score on this scale indicates the respondent values a job that is interesting and enjoyable.

The mean for the Task Satisfaction scale was 32.31 , indicating respondents assigned great importance to Task Satisfaction in their jobs. This mean was the highest of all the work value scales. The standard deviation was 3.25 , and the median was 33.80. The mode was 35 , the highest possible score for the scale. The distribution for this scale was the most skewed of all the scales with a skewness of -1.1 . The frequency distribution of scores for the Task Satisfaction scale is presented in Table XXVIII.

\section{$\underline{\text { Solitude }}$}

The construct of Solitude is related to the preference for work situations characterized by the absence of close 
TABLE XXVIII

FREQUENCY DISTRIBUTION OF SCORES ON TASK SATISFACTION

\begin{tabular}{crrr}
\hline Score & Frequency & Percent & Cumulative Percent \\
\hline 35 & 154 & 39.7 & 100.0 \\
34 & 55 & 14.2 & 60.3 \\
33 & 32 & 8.2 & 46.1 \\
32 & 22 & 5.7 & 37.9 \\
31 & 17 & 4.4 & 32.2 \\
30 & 22 & 5.7 & 27.8 \\
29 & 17 & 4.4 & 22.2 \\
28 & 35 & 9.0 & 17.8 \\
27 & 10 & 2.6 & 8.8 \\
26 & 7 & 1.8 & 6.2 \\
25 & 8 & 2.1 & 2.3 \\
24 & 4 & 1.0 & 1.3 \\
23 & 2 & 0.5 & 0.8 \\
22 & 1 & 0.3 & 0.5 \\
21 & 1 & 0.3 & \\
20 & 1 & 0.3 & \\
\hline TOTAL & & & \\
\hline
\end{tabular}

relationships with other people. The work can be done largely by one person, and it usually affords either few or brief structured personal encounters. A higher score on this scale reflects the desire for work that is done in relative isolation or solitude.

The mean for the Solitude scale was 14.96, the lowest of all the scale means. This indicates respondents assigned little importance to work done in relative isolation or solitude. The standard deviation was 4.94. The median was 14.30, with a mode of 14. The frequency distribution for the scores on the Solitude scale are presented in Table XXIX.

Reproduced with permission of the copyright owner. Further reproduction prohibited without permission. 
TABLE XXXIX

FREQUENCY DISTRIBUTION OF SCORES ON SOLITUDE

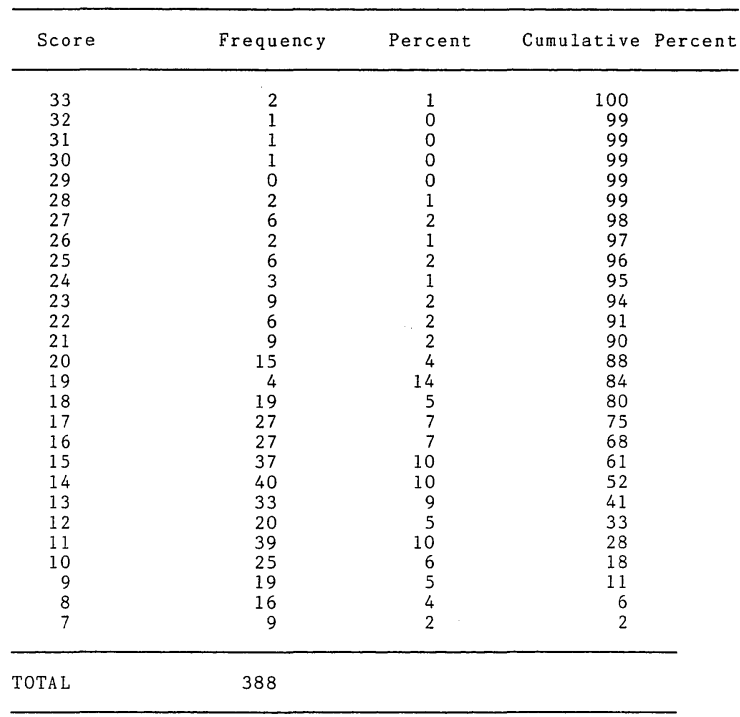

Ideas/Data Orientation

The measures on the Ideas/Data scale indicate the importance one gives to having an opportunity to work with facts and ideas. A high score on this scale signifies a preference for dealing with, making sense out of, creating and communicating ideas.

Reproduced with permission of the copyright owner. Further reproduction prohibited without permission. 
The mean of the Ideas/Data Orientation scale was 28.81 , indicating respondents assigned considerable importance to this work value. The standard deviation was 4.28. The median was 28.60 , with a mode of 28 . Table XXX presents the frequency distribution for the Ideas/Data Orientation scale.

TABLE XXX

FREQUENCY DISTRIBUTION FOR SCORES ON IDEAS/DATA

\begin{tabular}{lcrr}
\hline Score & Frequency & Percent & Cumulative Percent \\
\hline 35 & 37 & 10 & 100 \\
34 & 32 & 8 & 90 \\
33 & 20 & 5 & 82 \\
32 & 23 & 6 & 77 \\
31 & 33 & 9 & 71 \\
30 & 28 & 7 & 63 \\
29 & 25 & 6 & 55 \\
28 & 49 & 13 & 49 \\
27 & 38 & 10 & 36 \\
26 & 26 & 7 & 37 \\
25 & 25 & 6 & 20 \\
24 & 14 & 4 & 13 \\
23 & 11 & 3 & 7 \\
22 & 6 & 2 & 5 \\
21 & 8 & 2 & 3 \\
20 & 3 & 1 & 2 \\
19 & 2 & 1 & 2 \\
18 & 2 & 1 & 1 \\
17 & 2 & 1 & 1 \\
16 & 1 & 0 & 1 \\
15 & 1 & 0 & 0 \\
14 & 1 & 0 & 0 \\
13 & 0 & 0 & 0 \\
12 & 0 & 0 & \\
11 & 1 & 0 & \\
\hline & & & \\
TAL & 388 & & \\
\hline
\end{tabular}

Reproduced with permission of the copyright owner. Further reproduction prohibited without permission. 


\section{Prestige}

The scale of Prestige measures the desire for work that will bring a person recognition. An aspect of this value is the opportunity to meet or associate with important people. A higher score on this scale signifies a preference for

TABLE XXXI

FREQUENCY DISTRIBUTION OF SCORES ON PRESTIGE

\begin{tabular}{|c|c|c|c|}
\hline Score & Frequency & Percent & Cumulative Percent \\
\hline 35 & 10 & 3 & 100 \\
\hline 34 & 6 & 2 & 97 \\
\hline 33 & 7 & 2 & 96 \\
\hline 32 & 3 & 1 & 94 \\
\hline 31 & 2 & 1 & 93 \\
\hline 30 & 4 & 1 & 93 \\
\hline 29 & 9 & 2 & 92 \\
\hline 28 & 14 & 4 & 89 \\
\hline 27 & 17 & 4 & 86 \\
\hline 26 & 15 & 4 & 81 \\
\hline 25 & 11 & 3 & 78 \\
\hline 24 & 15 & 4 & 75 \\
\hline 23 & 21 & 5 & 71 \\
\hline 22 & 27 & 7 & 65 \\
\hline 21 & 24 & 6 & 59 \\
\hline 20 & 20 & 5 & 52 \\
\hline 19 & 15 & 4 & 47 \\
\hline 18 & 19 & 5 & 43 \\
\hline 17 & 22 & 6 & 38 \\
\hline 16 & 24 & 6 & 33 \\
\hline 15 & 27 & 7 & 27 \\
\hline 14 & 19 & 5 & 20 \\
\hline 13 & 11 & 3 & 15 \\
\hline 12 & 13 & 3 & 12 \\
\hline 11 & 11 & 3 & 9 \\
\hline 10 & 9 & 2 & 6 \\
\hline 9 & 8 & 2 & 3 \\
\hline 8 & 0 & 0 & 1 \\
\hline 7 & 5 & 1 & 1 \\
\hline TOTAL & 388 & & \\
\hline
\end{tabular}

Reproduced with permission of the copyright owner. Further reproduction prohibited without permission. 
having a job that brings recognition and allows one to meet or associate with important people.

The mean of the Prestige scale was 20.24, indicating respondents assigned moderate importance to this value. The standard deviation was 6.53. The median was 20.10, with a mode of 15. Table XXXI presents the frequency distribution of the scores on Prestige.

\section{Summary}

The scoring procedures and scale definitions were reviewed. Means, standard deviations, medians and modes were reported for all scales. The work value of Task Satisfaction had, the highest mean for the sample, indicating respondents assigned great importance to work that is interesting and enjoyable. The work value of Solitude had the lowest mean of all the values measured, indicating little importance was given to a job in which the administrator had few or brief structured encounters with other individuals. Administrators did not highly value work situations characterized by the absence of close relationships with other people.

Self-realization was valued in the "considerable" to "great" range of values. Administrators in the sample highly valued work permitting one to utilize one's skills, abilities or talents and highly valued work providing the opportunity for continued personal growth and realization of the administrator's full potential.

Reproduced with permission of the copyright owner. Further reproduction prohibited without permission. 
Considerable importance was assigned to the work values of Altruism, Independence and Ideas/Data Orientation. Respondents considerably valued a job that provided opportunities to work with other people in a helping, supportive role; one that allowed independence in determining working conditions and was free from close supervision, and one that provided an opportunity to work with and communicate facts and ideas.

Moderate to considerable importance was assigned to the work values of Control and Money. These scales measure tne importance the administracor assigned to taking a leadership role or responsibility for other workers and the importance the administrator assigned to having a substantial income, earning more than cnough money to satisfy life's basic needs.

Finally, respondents assigned moderate importance to the work values of Security, Prestige and Object Orientation. Administrators only moderately valued a job immune to unpredictable layoffs and was steady and dependable. Similarly, the administrators moderately desired a job bringing recognition and an opportunity to meet and associate with important people and moderately desired a job in which the administrator handles or manipulates physical objects, such as utensils, materials, tools or apparatus.

Reproduced with permission of the copyright owner. Further reproduction prohibited without permission. 
Scoring of the ARPI

This section presents the scoring procedures for the Administrator Role Perception Inventory (ARPI), the instrument employed to measure administrator burnout. After the scoring procedures are presented, analyses of the data from the ARPI will follow.

The Administrator Role Perception Inventory consists of 50 items, divided equally among the five subscales of Expectation, Motivation, Psycho-physical State, Relationships and Accomplishment. The sixth subscale, Time, is composed of items selected from the other five subscales. The items for the Time subscale are not evenly distributed across the other subscales. Wax (1983, p. 73) developed the following table to indicate the assignment of the ARPI items to the subscales.

TABLE XXXII

ASSIGNMENT OF ARPI ITEMS TO SUBSCALES

Subscale

I tems

Expectation

Motivation

Psycho-physical State

Relationships

Accomplishment

Time
$1,6,11,16,21,26,31,36,41,46$

$2,7,12,17,22,27,32,37,42,47$

$3,8,13,18,23,28,33,38,43,48$

$4,9.14,19,24,29,34,39,44,49$

$5,10,15,20,25,30,35,40,45,50$

$3,19,28,33,38,39,49,50$

Reproduced with permission of the copyright owner. Further reproduction prohibited without permission. 
Respondents were asked to read each statement in the ARPI and decide to what extent they agreed or disagreed with the statement. Respondents were asked to mark an "x" on the line that corresponded best to their opinion. For each question, one of the following responses was asked to be chosen: strongly disagree, disagree, neutral, agree or strongly agree. The items were scored from one to five, in the aforementioned order. Each of the subscales, except Time has a maximum score of 50 and a minimum score of 10 , since a total of ten items composed each subscale, except Time. The subscale, Time, consists of eight items. Therefore, the highest possible score on the Time subscale is 40 , and the lowest possible score on the Time subscale is eight. The subscales were designed by the authors such that higher scores correspond with perceptions of one's situation as more positive, "healthier," and less burned-out. Thus, items written in the negative were given a reverse scoring.

Analysis of the Subscales of the ARPI and the Total ARPI

The descriptive statistics for the scores on the subscales of the ARPI and the score for the complete ARPI follow. First, a summary of the means and standard deviations for the entire inventory and each subscale is presented. Then, a more detailed description of the statistics for each subscale and the entire ARPI follows. 
There is not normative data for this instrument; therefore, the reported means are unanchored.

\section{Summary of the Scores}

The mean of the Total ARPI was 179.03 of a possible 290. The means for each subscale ranged from 29.30 to 40.19. The standard deviation for the Total ARPI was 21.63, and the standard deviations of the six subscales ranged from 4.83 to 7.17. Table XXXIII summarizes these statistics in more detail.

TABLE XXXIII

MEANS \& STANDARD DEVIATIONS FOR SUBSCALES AND TOTAL ARPI

\begin{tabular}{|c|c|c|}
\hline Subscale & Mean & Standard Deviation \\
\hline $\begin{array}{l}\text { Expectation } \\
\text { Motivation } \\
\text { Psycho-physical State } \\
\text { Relationships } \\
\text { Accomplishment } \\
\text { Time* } \\
\text { Total ARPI }\end{array}$ & $\begin{array}{r}29.30 \\
36.06 \\
34.05 \\
39.44 \\
40.19 \\
29.31 \\
179.03\end{array}$ & $\begin{array}{r}6.15 \\
5.32 \\
7.17 \\
5.07 \\
4.83 \\
5.03 \\
21.63\end{array}$ \\
\hline
\end{tabular}

*Time is an eight-item scale.

All of the aforementioned scores in Table XXXIII are higher than those scores reported by Wax (1983), indicating this sample of administrators appears to be less burned-out than those surveyed in 1982 (see Appendix E).

\section{Expectation}

The construct of Expectation is defined as the degree 
of discrepancy in one's job between one's reality and one's anticipated reality. A higher score on this subscale indicates that there is a smaller discrepancy between the individual's job expectations and the reality of the job.

The mean score of the Expectation subscale was 29.30, with a standard deviation of 6.15. The median was 29.10, indicating the distribution was generally symmetrical. The mode, or most frequently occurring score, was 34 . Table XXXIV presents the frequency distribution for the scores on the Expectation subscale.

TABLE XXXIV

FREQUENCY DISTRIBUTION OF SCORES ON EXPECTATION

\begin{tabular}{lccc}
\hline Score & Frequency & Percent & Cumulative Percent \\
\hline $47-49$ & 1 & 0 & 100 \\
$44-46$ & 4 & 1 & 100 \\
$41-43$ & 9 & 3 & 99 \\
$38-40$ & 23 & 6 & 96 \\
$35-37$ & 39 & 11 & 90 \\
$32-34$ & 65 & 17 & 64 \\
$29-31$ & 65 & 16 & 47 \\
$26-28$ & 72 & 15 & 28 \\
$23-25$ & 57 & 3 & 5 \\
$20-22$ & 34 & 2 & 3 \\
$17-19$ & 14 & & \\
$14-16$ & 5 & & \\
\hline
\end{tabular}

Motivation

The construct of Motivation is defined as the 
propensity to initiate action; the inclination toward proactivity. A higher score on the Motivation subscale indicates higher motivation. The mean of the Motivation subscale was 36.06 with a standard deviation of 5.32. The median was 36.30 , indicating a generally symmetrical distribution. The mode, or most frequent1y occurring score, was 38. Table XXXV presents the frequency distribution for the scores on the Motivation subscale.

TABLE XXXV

FREQUENCY DISTRIBUTION OF SCORES ON MOTIVATION

\begin{tabular}{lccc}
\hline Score & Frequency & Percent & Cumulative Percent \\
\hline $48-50$ & 7 & 1 & 100 \\
$45-47$ & 16 & 5 & 98 \\
$42-44$ & 32 & 8 & 94 \\
$39-41$ & 72 & 18 & 86 \\
$36-38$ & 87 & 22 & 45 \\
$33-35$ & 73 & 19 & 26 \\
$30-32$ & 62 & 6 & 10 \\
$27-29$ & 24 & 3 & 1 \\
$24-26$ & 10 & 0 & 1 \\
$21-23$ & 2 & & \\
$18-21$ & 3 & & \\
\hline TOTAL & 388 & & \\
\hline
\end{tabular}

Psycho-physical State

The construct of Psycho-physical State is defined as the overall mental, emotional and physical vigor of an individual. A higher score on the Psycho-physical State 
subscale indicates the individual has greater mental, emotional and physical vigor.

The mean for the Psycho-physical State subscale was 34.05. The standard deviation was 7.17. The median was 34.25, indicating a generally symmetrical distribution. The mode was 30. Table XXXVI presents the frequency distribution of the scores of the Psycho-physical State subscale.

TABLE XXXVI

FREQUENCY DISTRIBUTION CF SCORES ON PSYCHO-PHYSICAL STATE

\begin{tabular}{lcrr}
\hline Score & Frequency & Percent & $\begin{array}{c}\text { Cumulative } \\
\text { Percent }\end{array}$ \\
\hline $48-50$ & 9 & 2 & 100 \\
$45-47$ & 21 & 6 & 98 \\
$42-44$ & 32 & 8 & 92 \\
$39-41$ & 50 & 13 & 84 \\
$36-38$ & 56 & 14 & 71 \\
$33-35$ & 62 & 13 & 41 \\
$30-32$ & 51 & 12 & 28 \\
$27-29$ & 45 & 9 & 16 \\
$24-26$ & 22 & 2 & 3 \\
$21-23$ & 20 & 0 & 1 \\
$18-20$ & 8 & & \\
$15-17$ & 2 & & \\
\hline TOTAL & 8 & & \\
\hline
\end{tabular}

\section{Relationships}

The construct of Relationships in the ARPI is defined as the desire for and the quality of continuous interaction with work-related colleagues and clients; the identification 
and involvement of self with colleagues and clients, and the acceptance of oneself by clients and colleagues. A higher score on the Relationships subscale indicates an individual has a stronger desire for relationships with colleagues and clients. Also, a higher score indicates there is greater identification, involvement and acceptance of the individual by the individual's colleagues and clients.

The mean score was 39.44 , with a standard deviation of 5.07. The median was 39.70 , indicating that the distribution was generally symmetrical. The mode was 40. Table XXXVII presents the frequency distribution on the Relationships subscale.

TABLE XXXVII

FREQUENCY DISTRIBUTION OF SCORES ON RELATIONSHIPS

\begin{tabular}{lccr}
\hline Score & Frequency & Percent & $\begin{array}{c}\text { Cumulative } \\
\text { Percent }\end{array}$ \\
\hline $48-50$ & 23 & 5 & 100 \\
$45-47$ & 41 & 11 & 94 \\
$42-44$ & 69 & 17 & 84 \\
$39-41$ & 109 & 15 & 66 \\
$36-38$ & 58 & 11 & 38 \\
$33-35$ & 44 & 2 & 23 \\
$30-32$ & 35 & 0 & 2 \\
$27-29$ & 8 & & 0 \\
$24-26$ & 1 & & \\
\hline
\end{tabular}

Reproduced with permission of the copyright owner. Further reproduction prohibited without permission. 
Accomplishment

The construct of the Accomplishment subscale is defined as the sense of attainment of one's professional goals. A higher score on the Accomplishment subscale indicates an individual possesses more positive feelings toward the accomplishment of those professional goals.

The mean score for Accomplishment was 40.19 , with a standard deviation of 4.83. The median score was 40.28 , indicating that the distribution was close to symmetrical. The mode was 40. Table XXXVIII presents the frequency distribution for the scores on the Accomplishment subscale.

TABLE XXXVIII

FREQUENCY DISTRIBUTION OF SCORES ON ACCOMPLISHMENT

\begin{tabular}{lrrr}
\hline Score & Frequency & Percent & $\begin{array}{c}\text { Cumulative } \\
\text { Percent }\end{array}$ \\
\hline $48-50$ & 25 & 7 & 100 \\
$45-47$ & 42 & 10 & 94 \\
$42-44$ & 79 & 21 & 83 \\
$39-41$ & 122 & 32 & 62 \\
$36-38$ & 60 & 16 & 31 \\
$33-35$ & 34 & 9 & 15 \\
$30-32$ & 20 & 5 & 2 \\
$27-29$ & 1 & 0 & 1 \\
$24-26$ & 3 & 0 & 0 \\
$21-23$ & 1 & 0 & \\
$18-20$ & 1 & & \\
\hline TOTAL & 388 & & \\
\hline
\end{tabular}

Reproduced with permission of the copyright owner. Further reproduction prohibited without permission. 
Time

The construct of the Time subscale is defined as the tendency to view the past as better than the present; a longing for the "good old days." A higher score on the Time subscale indicates the individual is content with the present and does not long for the "good old days."

The mean score on the Time subscale was 29.31 , with a standard deviation of 5.03. The median was 29.50 , indicating a generally symmetrical distribution. The mode was 31 . Table XXXIX presents the frequency distribution of the scores on the Time subscale.

TABLE XXXIX

FREQUENCY DISTRIBUTION OF SCORES ON TIME

\begin{tabular}{lccc}
\hline Score & Frequency & Percent & $\begin{array}{c}\text { Cumulative } \\
\text { Percent }\end{array}$ \\
\hline $38-40$ & 25 & 6 & 100 \\
$35-37$ & 33 & 8 & 94 \\
$32-34$ & 62 & 17 & 85 \\
$29-31$ & 104 & 19 & 42 \\
$26-28$ & 77 & 15 & 22 \\
$23-25$ & 56 & 5 & 4 \\
$20-22$ & 16 & 1 & 1 \\
$17-19$ & 13 & & \\
$14-16$ & 2 & & \\
\hline TOTAL & & & \\
\hline
\end{tabular}

Reproduced with permission of the copyright owner. Further reproduction prohibited without permission. 
Tota1 ARPI

The Total administrator role perception scale measures the administrator's unique and private perception of his or her phenomenological world in terms of expectation, motivation, accomplishment, relationships, psycho-physical state and time orientaion. A higher Total ARPI score corresponds to a more positive, "healthier," less burned-out view of one's world.

The mean was 179.03 of a possible 290, indicating moderate burnout perceptions of the administrators in the sample. That is, on a scale of one to five with one indicating extreme burnout and five indicating the most "healthy" role perceptions, the mean approximately was three. The standard deviation was 21.63. The median was 178.64. The distribution was fairly symmetrical. The mode was 182 . Table XL presents a frequency distribution of the Total ARPI scores.

\section{$\underline{\text { Summary }}$}

The scoring procedures, subscale definitions and definition of an administrator role perception were reviewed. Means, standard deviations, medians and modes were reported for all subscales and for the Total ARPI scale. The frequency distributions for all subscales and for the Total ARPI scale generally were found to be symetrical.

Reproduced with permission of the copyright owner. Further reproduction prohibited without permission. 
TABLE XL

FREQUENCY DISTRIBUTION OF TOTAL ARPI SCORES

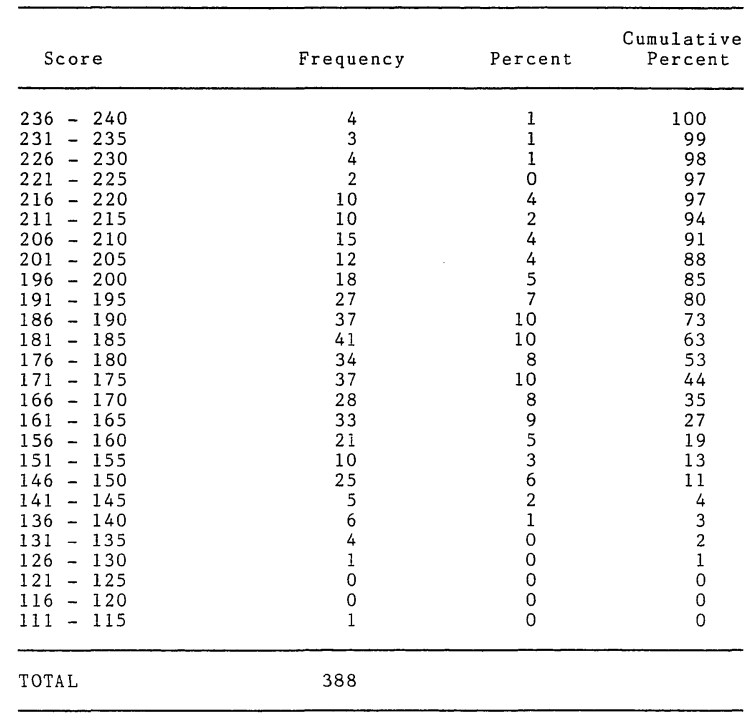


The data indicated that respondents scored the highest on the Accomplishment and Relationships subscales, with means of 40.19 and 39.44 , respectively. This indicates that respondents had a stronger identification, involvement and acceptance of the individual by the individual's colleagues and clients and a stronger desire for relationships with colleagues and clients. Additionally, this indicates that respondents possessed more positive feelings toward the accomplishment of their professional goals.

The respondents scored the lowest on the Expectation subscale, having a mean of 29.30. This indicates that there was a larger discrepancy between the administrators' expectations and the reality of their jobs.

The mean for the Time subscale (29.31) reflects a subscale composed of only eight items, as compared with the 10 items on each of the other subscales of the ARPI.

The Total ARPI scale mean (179.03) indicated administrators providing data for this research perceived moderate burnout. That is, on a scale of one to five with one indicating the most burned-out perceptions and five indicating the most "healthy", least burned-out perceptions, the mean for the administrators in this sample corresponded to approximately a three.

A11 ARPI scale and subscale means were higher than those reported by Wax (1983), indicating respondents perceived less burnout than those previously surveyed.

Reproduced with permission of the copyright owner. Further reproduction prohibited without permission. 
Relationships Between Instruments and Biographical Data

Of central importance to this research are the relationships between the biographical data and administrator role perceptions, as measured by the Administrator Role Perception Inventory, and administrator work values, as measured by the Ohio Work Values Inventory. Additionally, this research endeavored to determine the relationships between administrator role perceptions and administrator work values. Therefore, this next section will report the relevant data of the relationships investigated. First, the relationships between the biographical data and the administrator role perceptions will be presented. Next will follow the relationships between administrator work values and the biographical data. Finally, the relationships between administrator role perceptions associated with burnout and their work values will be reported.

Relationships Between Biographical Data and ARPI

Coefficients of correlation were calculated between biographical data, the ARPI subscales and the Total ARPI scale. These correlations are presenied in Table XLI.

Reproduced with permission of the copyright owner. Further reproduction prohibited without permission. 
TABLE XLI

CORRELATIONS OF BIOGRAPHICAL DATA WITH ARPI

\begin{tabular}{lrrrrrrr} 
Bio. Data & Exp. & Mot. & P S & Rel. & Acc. & Time & Tot ARPI \\
\hline Sex & .00 & .02 & -.01 & .05 & -.04 & .01 & .00 \\
Age & .13 & -.07 & .13 & .04 & -.07 & .08 & .06 \\
Degree & .09 & -.04 & .02 & .14 & .01 & .05 & .06 \\
Yrs Same Job & -.02 & -.12 & -.02 & -.04 & -.11 & -.06 & -.08 \\
Yrs of Admin. & .02 & -.18 & .02 & .02 & -.08 & -.04 & -.05 \\
\hline
\end{tabular}

Six of the 35 correlations presented above in Table XLI though numerically small were significant at the .05 level or above. Table XLII presents the statistically significant correlations of the ARPI subscales and the Total ARPI scale with the biographical descriptors and the level of significance, if that level was .05 or above.

TABLE XLII

STATISTICALLY SIGNIFICANT CORRELATIONS AND LEVEL OF SIGNIFICANCE WITH ARPI

\begin{tabular}{lccccc}
\hline Bio. Data & Exp. & Mot. & P S & Re1. & Acc. \\
\hline Age & .01 & & .01 & & \\
Degree & & & .01 & \\
Yrs Same Job & & .05 & & & .05 \\
Yrs of Admin & .001 & & & \\
\hline
\end{tabular}

Reproduced with permission of the copyright owner. Further reproduction prohibited without permission. 
Summary of Statistically Significant Correlations

The following is a summary of the significant correlations between the biographical data, the ARPI subscales and the Total ARPI scale.

The age of the administrator was positively correlated with the subscales of Expectation and Psycho-physical State. The administrator's degree was positively correlated with the Relationship subscale. The total years an administrator held the same job at the same location was negatively correlated with the Motivation and Accomplishment subscales, and the total number of years in educational administration was negatively correlated with Motivation, also.

Relationships Between Biographical Data and OWVI

Coefficients of correlation were calculated between biographical data and the OWVI scales. These correlations are presented in Table XLIII.

\section{TABLE XLIII}

CORRELATIONS OF BIOGRAPHICAL DATA WITH OWVI

\begin{tabular}{|c|c|c|c|c|c|c|c|c|c|}
\hline & Alt & objo & $\mathrm{Sec}$ & Con & In & Mon & TS & $I / D$ & $\operatorname{Pr}$ \\
\hline Sex & -.06 & -.04 & -.04 & -.04 .06 & -.05 & -.05 & -.01 & -.06 .06 & .03 \\
\hline Age & .02 & .05 & .06 & $-.09-.14$ & -.06 & -.08 & -.05 & $.02-.08-$ & .14 \\
\hline Degree & .00 & -.02 & -.04 & $-.09-.09$ & -.06 & -.03 & -.09 & $.01-.05$ & .04 \\
\hline YrSamJb & .04 & .11 & .10 & $.02-.07$ & .04 & -.03 & -.09 & $.08-.10$ & .01 \\
\hline YrAdmin & .04 & .04 & .05 & $-.00-.17$ & -.08 & -.04 & -.07 & $.01-.11-$ & .07 \\
\hline
\end{tabular}

Reproduced with permission of the copyright owner. Further reproduction prohibited without permission. 
Table XLIV presents the statistically significant correlations of the OWVI scales with the biographical data and the level of significance, if the level of significance was TABLE XLIV

STATISTICALLY SIGNIFICANT CORRELATIONS AND LEVEL OF SIGNIFICANCE WITH OWVI

\begin{tabular}{lccc}
\hline Scale & Age & Yrs Sam Job & Yrs Admin \\
\hline Object Orientation & & .05 & \\
Security & .01 & .05 & .001 \\
Self-realization & .01 & .05 & .05 \\
Ideas/Data & .01 & & \\
\hline
\end{tabular}

\section{Summary of Statistically Significant Correlations}

The following is a summary of the statistically significant correlations between the biographical data and the OWVI scales, with level of significance at .05 or above.

The age of the administrator was negatively correlated with the scales of Self-realization and Prestige. The years the administrator held the same job at the same location was postively correlated with the scales of Object Orientation and Security but was negatively correlated with the Ideas/Data scale. The total years an individual had been an educational administrator was negatively correlated with the Self-realization scale and the Ideas/Data Orientation scale. Relationship Between OWVI and ARPI

The coefficient of correlation was calculated between 
each OWVI scale, each ARPI subscale and the Total ARPI scale in order to determine relationships between administrator role perceptions associated with burnout and the administrator's work values. The correlations are presented in Table XLV.

TABLE XLV

CORRELATIONS BETWEEN ARPI AND OWVI

\begin{tabular}{lrrrrrrr}
\hline Scale & Exp. & Mot. & P S & Rel. & Acc. & Time & Tot ARPI \\
\hline Altruism & -.02 & .17 & .10 & .25 & .28 & .15 & .19 \\
Obj0rient & -.11 & -.03 & -.08 & .01 & .04 & -.04 & -.05 \\
Security & -.11 & -.02 & -.06 & .01 & -.01 & -.03 & -.06 \\
Control & .06 & .23 & .09 & .08 & .19 & .09 & .16 \\
Self-real & -.06 & .26 & .04 & .29 & .31 & .15 & .20 \\
Indepen & -.10 & -.00 & -.07 & -.04 & .11 & -.08 & -.04 \\
Money & -.07 & -.04 & -.08 & -.06 & .04 & -.07 & -.06 \\
TaskSat. & -.09 & .13 & -.03 & .21 & .20 & .06 & .09 \\
Solitude & -.09 & -.19 & -.21 & -.19 & -.19 & -.23 & -.023 \\
IdealData & .12 & .40 & .19 & .20 & .38 & .22 & .33 \\
Prestige & .03 & .24 & .05 & .01 & .17 & .02 & .13 \\
\hline
\end{tabular}

Many of the correlations reported in Table XLV are statistically significant at the .05 level or above. These statistically significant correlations between the OWVI scales and the ARPI subscales and the ARPI Total scale and the level of significance are reported in Table XLVI.

Reproduced with permission of the copyright owner. Further reproduction prohibited without permission. 
TABLE XLVI

STATISTICALLY SIGNIFICANT CORRELATIONS BETWEEN OWVI AND ARPI AND LEVEL OF SIGNIFICANCE

\begin{tabular}{|c|c|c|c|c|c|c|c|}
\hline Scale & Exp. & Mot. & P S & Rel. & AcC. & Time & Tot ARPI \\
\hline Altruism & & .001 & .05 & .001 & .001 & .01 & .001 \\
\hline Object Or & .05 & & & & & & \\
\hline Security & .05 & & & & & & \\
\hline Control & & .001 & & & .001 & & .001 \\
\hline Self-real & & .001 & & .001 & .001 & .01 & .001 \\
\hline Independeno & & & & & .05 & & \\
\hline Task Satis & & .01 & & .001 & .001 & & \\
\hline Solitude & & .001 & .001 & .001 & .001 & .001 & .001 \\
\hline Ideas/Data & .05 & .001 & .001 & .001 & .001 & .001 & .001 \\
\hline Prestige & & .001 & & & .001 & & .01 \\
\hline
\end{tabular}

Summary of Statistically Significant Correlations

The following is a summary of the statistically significant correlations between the OWVI scales and the ARPI subscales and Total ARPI scale. All significant correlations are at the .05 level or above.

The Altruism scale was positively correlated with the Total ARPI scale and all subscales of the ARPI except Expectation. Altruism was negatively correiated with the Expectation subscale; however, the level of significance was below .05. The scales of object Orientation and Security were negatively correlated to the individual's score on the 
Expectation subscale. The scale of Control was found to be positively correlated with the subscales of Motivation and Accomplishment and the Total ARPI scale. The Selfrealization scale was found to be positively correlated with the Total ARPI scale and the subscales of Motivation, Relationships, Accomplishment and Time. The scale of Independence was positively correlated with the administrators' Accomplishment score. The Money scale was not statistically significantly correlated with any of the ARPI subscales nor the Total ARPI scale. The Task Satisfaction scale was positively correlated with the subscales of Motivation, Relationship and Accomplishment. The scale of Solitude was significantly negatively correlated with the Total ARPI scale and all ARPI subscales except Expectation. Expectation was negatively correlated with Solitude, also. However, the level of significance was .06 . Ideas/Data Orientation was found to be positively correlated with all ARPI subscales as well as with the Total ARPI scale. Final1y, the Prestige scale was positively correlated with the subscales of Motivation and Accomplishment as well as with the Total ARPI scale.

Relationship Between OWVI, ARPI and Subject's Sex Multivariate analyses of variance were performed using respondent's sex as the independent variable and the scales and of the Ohio Work Values Inventory and subscales the Administrator Role Perception Inventory as the dependent 
variable, with alpha level set at .05 for each analysis, to determine whether there were statistically significant differences in the work values of male and female administrators and differences in burnout of male and female administrators. The statistical hypotheses that there would be no difference between the means of the OWVI scales and the sex of the respondent was rejected; the statistical hypothesis for the ARPI subscales was not rejected. Subsequent univariate analyses of variance using the Scheffé test revealed statistically significant differences between the sex of the respondent and the two work values of Self-realization and Ideas/Data Orientation, with women assigning statistically significantly greater importance to those two work values. On all other nine work values, there were no significant differences between male and female respondents. Table XLVII provides the analysis of variance for the Selfrealization scale, and Table XLVIII provides the male/female group means on the Self-realization scale.

TABLE XLVII

ANOVA FOR SELF-REALIZATION SCALE AND SEX OF RESPONDENT

\begin{tabular}{lrrr}
\hline Source of Variation & df & MS & F \\
\hline Between groups & 1 & 123.70 & $11.97 *$ \\
Within groups & 381 & $3,938.19$ & \\
\hline
\end{tabular}

${ }^{*} \mathrm{p}<.001$

Reproduced with permission of the copyright owner. Further reproduction prohibited without permission. 
TABLE XLVIII

SELF-REALIZATION SCALE GROUP MEANS

\begin{tabular}{lccr}
\hline Group & Mean & Std. Dev. & n \\
\hline Male & 31.40 & 3.31 & 275 \\
Female & 32.67 & 2.96 & 108 \\
\hline
\end{tabular}

Table IL provides the analysis of variance for the Ideas/Data Scale, and Table L presents the group means of male and female administrators for the Ideas/Data scale.

TABLE IL

ANOVA FOR IDEAS/DATA SCALE AND SEX OF RESPONDENT

\begin{tabular}{lrrr}
\hline Source of Variation & df & MS & F \\
\hline Between groups & 1 & 122.4819 & $6.82 *$ \\
Within groups & 381 & $6,838.0886$ & \\
\hline *p $<.01$ & & &
\end{tabular}

TABLE L

IDEAS/DATA SCALE GROUP MEANS

\begin{tabular}{lccr}
\hline Group & Mean & Std. Dev. & n \\
\hline Male & 28.47 & 4.42 & 275 \\
Female & 29.72 & 3.72 & 108 \\
\hline
\end{tabular}

Reproduced with permission of the copyright owner. Further reproduction prohibited without permission. 


\section{Summary of Sex Differences}

There were no statistically significant differences between male and female administrators on all measures of burnout, as measured by the subscales of the ARPI and the Total ARPI scale. There were no statistically significant differences between the work values of male and female administrators on nine of the 11 work values measured by the OWVI. Women administrators assigned statistically significantly more importance to the work values of Selfrealization and Ideas/Data Orientation.

Relationship Between OWVI, ARPI and Job Location

The statistical hypotheses that there would be no significant difference between group means of the OWVI scales and ARPI subscales and the respondent's job location were rejected.

As in the case of the sex of the respondent, multivariate analyses of variance were performed on the job location (Central Office, Elementary, Middle School/Junior High School or High School) and the scales of the OWVI and the subscales of the ARPI, using job level as the independent variable and the scales of the OWVI and subscales of the ARPI as the dependent variables, with alpha set at .05 for each analysis, to determine whether there were statistically significant differences in the work values of administrators at different job locations and whether there were differences in burnout of administrators in different job locations. 
Subsequent univariate analyses of variance were performed to determine which scales and subscales differed statistically significantly on the respondent's job location. For five of the univariate analyses the statistical hypothesis that there would be no statistically significant difference between an administrator's job level and the scale/subscale mean with alpha set at .05 for each analysis was rejected. Means for the Altruism, Independence and Prestige scales and Relationship and Time subscales were found to be statistically significantly different. Table LI presents the analysis of variance for the Altruism scale.

TABLE LI

ANOVA FOR ALTRUISM SCALE AND JOB LOCATION

\begin{tabular}{lrrr}
\hline Source of Variation & df & MS & F \\
\hline Between groups & 3 & 60.89 & $2.73^{*}$ \\
Within groups & 381 & 22.29 & \\
\hline
\end{tabular}

$* \mathrm{p}<.05$

Table LII presents the analysis of variance for the Independence scale.

TABLE LII

ANOVA FOR INDEPENDENCE SCALE AND JOB LOCATION

\begin{tabular}{lrrr}
\hline Source of Variation & df & MS & F \\
\hline Between groups & 3 & 132.73 & $5.56 *$ \\
Within groups & 381 & 23.88 & \\
\hline *p $<.001$ & & &
\end{tabular}

Reproduced with permission of the copyright owner. Further reproduction prohibited without permission. 
Table LIII presents the analysis of variance for the Prestige scale of the OWVI.

TABLE LIII

ANOVA FOR PRESTIGE SCALE AND JOB LOCATION

\begin{tabular}{lrrr}
\hline Source of Variation & df & MS & F \\
\hline $\begin{array}{l}\text { Between groups } \\
\text { Within groups }\end{array}$ & 3 & $\begin{array}{r}3 \\
\text { (58.39 }\end{array}$ & $3.79 *$ \\
\hline p $<.05$ & & & \\
\hline
\end{tabular}

Table LIV presents the analysis of variance for the Relationship subscale of the ARPI.

TABLE LIV

ANOVA FOR RELATIONSHIP SUBSCALE AND JOB LOCATION

\begin{tabular}{lrrrr}
\hline Source of Variation & df & MS & F \\
\hline $\begin{array}{lrrr}\text { Between groups } \\
\text { Within groups }\end{array}$ & $\begin{array}{r}3 \\
\text { Whin }\end{array}$ & $\begin{array}{r}816.88 \\
19.51\end{array}$ & $41.87 \%$ \\
\hline
\end{tabular}

${ }^{*} \mathrm{p}<.001$

Table LV presents the analysis of variance for the Time subscale of the ARPI.

TABLE LV

ANOVA FOR TIME SUBSCALE AND JOB LOCATION

\begin{tabular}{lrrrc}
\hline Source of Variation & df & MS & F \\
\hline $\begin{array}{l}\text { Between groups } \\
\text { Within groups }\end{array}$ & 3 & 31 & $\begin{array}{l}89.34 \\
24.87\end{array}$ & $3.59 *$ \\
\hline
\end{tabular}

*p<.05

Reproduced with permission of the copyright owner. Further reproduction prohibited without permission. 
The statistical hypotheses were rejected at the .05 level of significance for the Altruism, Independence and Prestige scales of the OWVI and the Relationship and Time subscales of the ARPI. Therefore, further analyses, using the Scheffe test, were conducted to determine which pairs of means differed significantly, with alpha set at .05 . Analysis of the data for the Altruism scale with administrator level revealed statistically significant differences between the means of central office administrators and elementary school administrators, with elementary school administrators assigning statistically significantly more importance to the work value of Altruism than central office administrators. Table LVI presents the group means for the Altruism scale.

TABLE LVI

ALTRUISM SCALE GROUP MEANS

\begin{tabular}{lccr}
\hline Group & Mean & Std. Dev. & $\mathrm{n}$ \\
\hline Elementary Sch. & 30.10 & 4.70 & 113 \\
High School & 29.27 & 3.99 & 70 \\
Middle/Jr. HS & 28.87 & 5.11 & 61 \\
Central Office & 28.42 & 4.89 & 141 \\
\hline
\end{tabular}

Analysis of the data for the Independence scale with administrator job level revealed significant differences between central office administrators and administrators at

Reproduced with permission of the copyright owner. Further reproduction prohibited without permission. 
the elementary, middle school/junior high school and high school levels of administration, with central office administrators assigning statistically significantly more importance to Independence than the building level administrators. Table LVII presents the group means of the four groups for the Independence scale.

TABLE LVII

INDEPENDENCE SCALE GROUP MEANS

\begin{tabular}{lccr}
\hline Group & Mean & Std. Dev. & n \\
\hline Central Office & 27.07 & 4.50 & 141 \\
Elementary Sch. & 25.25 & 5.21 & 113 \\
Middle/Junior HS & 24.80 & 5.06 & 61 \\
High School & 24.76 & 4.96 & 70 \\
\hline
\end{tabular}

Analysis of the data for the Prestige scale of the OWVI with administrator job level revealed statistically significant differences between the means of central office administrators and elementary school administrators, with central office administrators assigning statistically significantly more importance to Prestige than elementary school administrators. Table LVIII presents the group means for the Prestige scale.

Reproduced with permission of the copyright owner. Further reproduction prohibited without permission. 
TABLE LVIII

PRESTIGE SCALE GROUP MEANS

\begin{tabular}{lccr}
\hline Group & Mean & Std. Dev. & $\mathrm{n}$ \\
\hline Central Office & 21.67 & 6.52 & 141 \\
Middle/Jr. HS & 19.69 & 6.41 & 61 \\
High School & 19.36 & 5.74 & 70 \\
Elementary & 19.23 & 6.82 & 113 \\
\hline
\end{tabular}

Analysis of the data for the Relationship subscale of the ARPI revealed statistically significant differences at the .05 level between central office administrators and the three levels of building administrators, with central office administrators assigning statistically significantly less importance to Relationships than the building level administrators at the elementary schools, middle schools/junior high schools and high schools.

Significant differences at the .10 level were found between middle school/junior high school and high school administrators and elementary school administrators using the Scheffé Test, with elementary school administrators assigning statistically significantly more importance to Relationships than middle school/junior high school or high school building administrators. Scheffé recommended using the .10 level of significance, since the Scheffé Test is so 
rigorous. Table LIX presents group means for the Relationship subscale of the ARPI.

TABLE LIX

RELATIONSHIP SUBSCALE GROUP MEANS

\begin{tabular}{lccr}
\hline Group & Mean & Std. Dev. & $\mathrm{n}$ \\
\hline Elementary & 42.27 & 4.20 & 113 \\
High School & 40.53 & 3.75 & 70 \\
Middle/Jr. HS & 40.39 & 4.72 & 61 \\
Central Office & 36.28 & 4.74 & 141 \\
\hline
\end{tabular}

Analysis of the data for the Time subscale of the ARPI with administrator job level revealed statistically significant differences between central office administrators and elementary school administrators, with elementary school administrators less likely to long for the "good old days" than central office administrators, since a higher score on the Time subscale indicates the individual is content with the present and does not long for the "good old days." Table LX presents the group means for the Time subscale. 
TABLE LX

TIME SUBSCALE GROUP MEANS

\begin{tabular}{lccr}
\hline Group & Mean & Std. Dev. & $\mathrm{n}$ \\
\hline Elementary & 30.27 & 5.06 & 113 \\
High School & 29.60 & 5.09 & 70 \\
Middle/Jr. HS & 29.57 & 5.61 & 61 \\
Central Office & 28.26 & 4.57 & 141 \\
\hline
\end{tabular}

Summary of Job Location Differences

Central office administrators differed from elementary school administrators on the work values of Altruism, Independence and Prestige. Central office administrators assigned statistically significantly more importance to Independence and Prestige and statistically significantly less importance to Altruism than elementary school administrators. Central office administrators valued Relationships less than the building level administrators at the elementary schools, middle school/junior high schools and high schools. Also, analysis of the data for the Time subscale of the ARPI revealed central office administrators were more likely to view the past as better than the present than elementary school administrators.

Using the .10 level of significance for the Scheffé Test, as is suggested by its author, elementary school administrators assigned more importance to Relationships than all other levels of administration.

Reproduced with permission of the copyright owner. Further reproduction prohibited without permission. 


\section{Measurement Characteristics of the Instruments}

Measurement characteristics of the Ohio Work Values Inventory (OWVI), the instrument used to measure administrator work values, and measurement characteristics of the Administrator Role Perception Inventory (ARPI), the instrument used to measure administrator role perceptions associated with burnout, will be presented in the following section. Although the intent of this research was not to test the reliability and validity of the instruments employed, analyses of reliability and validity data for the sample population is useful in interpreting the data from this investigation.

Ohio Work Values Inventory

Analyses of the internal consistency, scale intercorrelations and factors of the OWVI follow to provide data on the reliability and validity of the OWVI with the sample population.

Reliability of the OWVI. The reliability of the Ohio Work Values Inventory was measured using Coefficient Alpha to determine the degree of internal consistency among the questions measuring a particular work value. That is, Coefficient Alpha was calculated to determine the extent to which the pool of items chosen to measure each of the 11 constructs of the OWVI accurately represents the total pool

Reproduced with permission of the copyright owner. Further reproduction prohibited without permission. 
of hypothetical items that could be used to measure the constructs of Altruism, Object Orientation, Security, Control, Self-realization, Independence, Money, Task Satisfaction, Solitude, Ideas/Data Orientation and Prestige.

The internal consistency of the items for each of the 11 OWVI scales are presented in Table LXI. Reliabilities for the scales ranged from .84 to .95 , indicating a reasonable degree of internal consistency for the items on the OWVI; the median was approximately . 88 .

TABLE LXI

COEFFICIENT ALPHA FOR EACH SCALE ON OWVI

Scale

Altruism

Object Orientation

Security

Control

Self-realization

Independence

Money

Task Satisfaction

Solitude

Ideas/Data Orientation

Prestige
Coefficient Alpha

.92

.86

.94

.92

.88

.84

.95

.88

.85

.88

.93

Scale Intercorrelations of the OWVI. The coefficients of correlation of each scale with each other scale were calculated and are presented in Table LXII in order to show the relationship between scales. The scale intercorrelations range from .64 (Self-realization with Task Satisfac- 
tion) to -.18 (Altruism with Solitude), with a median value of approximately .22.

TABLE LXII

SCALE INTERCORRELATIONS OF OWVI

\begin{tabular}{|c|c|c|c|c|c|c|c|c|c|c|}
\hline Scale & Objo & $\mathrm{Sec}$ & Con & $\mathrm{SR}$ & Ind & Mon & TS & Sol & $I / D$ & Pres \\
\hline Altrusim & .13 & .20 & .21 & .48 & .17 & .06 & .42 & -.18 & 3.43 & .22 \\
\hline \multicolumn{2}{|c|}{ Object Orientation } & .14 & .09 & .11 & .12 & .06 & .09 & .11 & .19 & .08 \\
\hline \multicolumn{2}{|l|}{ Security } & & .32 & .23 & .29 & .41 & .24 & .14 & +.02 & .20 \\
\hline \multicolumn{2}{|l|}{ Control } & & & .31 & .38 & .29 & .18 & .10 & .30 & .47 \\
\hline \multicolumn{2}{|c|}{ Self-realization } & & & & .33 & .16 & .64 & -.06 & 5.60 & .25 \\
\hline \multicolumn{2}{|c|}{ Independence } & & & & & .50 & .39 & .32 & .26 & .36 \\
\hline \multicolumn{2}{|l|}{ Money } & & & & & & .31 & .12 & 2.11 & .32 \\
\hline \multicolumn{2}{|c|}{ Task Satisfaction } & & & & & & & .02 & 2.37 & .20 \\
\hline \multicolumn{2}{|l|}{ Solitude } & & & & & & & & -.01 & .11 \\
\hline \multicolumn{2}{|l|}{ Ideas/Data } & & & & & & & & & .33 \\
\hline
\end{tabular}

Validity of the OWVI. A factor analysis, using oblimin rotation, was performed on the responses of the sample on the 77 items on the OWVI. The factor analysis yielded 14 factors. Nine of the factors exhibited congruence with nine of the scales of the OWVI, in that the principle loadings of the items were on the scales to which they were assigned. Two factors were associated with the Solitude scale. One of these items loaded equally on another factor; this second 
factor contained no other item with a principal loading. The items of Self-realization formed two factors; for each of these two factors the items that had principal loadings on the factor had noticeable secondary loadings on the other factor. The results of this factor analysis demonstrates construct validity of the OWVI.

\section{Summary}

Although the intent of this research was not to prove the reliability or validity of the Ohio Work Values Inventory, analyses of the reliability and validity measures have indicated that the OWVI demonstrated satisfactory reliability and validity for this population.

The reliability coefficients indicated a reasonable degree of internal consistency for the items of the OWVI, ranging from .84 for the Independence scale to .95 for the work value of Money; the median was approximately .88. Scale intercorrelations were calculated to show the relationship between the 11 work value scales. Analysis indicated that the scale intercorrelations ranged from $\quad .64$ (Self-realization with Task Satisfaction) to -.18 (Altruism with Solitude), with a median value of approximately .22 .

A factor analysis, using oblimin rotation, was performed on the responses of the sample on the 77 OWVI items. This analysis yielded 14 factors. Subsequent analysis of the principle and secondary loadings supported the conclusion of construct validity of the OWVI.

Reproduced with permission of the copyright owner. Further reproduction prohibited without permission. 
Administrator Role Perception Inventory

Analyses of the internal consistency, subscale intercorrelations and the administrators' self-perceptions of job stress, personal stress and burnout and their Total ARPI scale follow to provide data on the reliability and validity of the ARPI with the sample population.

Reliability of the ARPI. The reliability of the Administrator Role Perception Inventory was examined using Coefficient Alpha to determine the degree of internal consistency among the questions measuring each role perception. That is, Coefficient Alpha was calculated to determine the extent to which the pool of items chosen to measure each of the six constructs of the ARPI accurately represented the total pool of hypothetical items that could be used to measure the constructs of Expectation, Motivation, Psychophysical State, Relationships, Accomplishment, Time and the Total measurement of burnout.

The internal consistency of the items for each of the six subscales and for the Total ARPI scale are represented in Table LXIII.

The reliabilities for the subscales ranged from a Coefficient Alpha of .74 for the Motivation subscale to .87 for the Psycho-physical State subscale, with a reliability measurement for the Total ARPI of .92. All of the measurements represented in Table LXII are higher than those reported by Wax (1983).

Reproduced with permission of the copyright owner. Further reproduction prohibited without permission. 
TABLE LXIII

COEFFICIENT ALPHA FOR EACH SUBSCALE AND FOR TOTAL ARPI

\begin{tabular}{lc}
\hline \multicolumn{1}{c}{ Scale } & Coefficient Alpha \\
\hline Expectation & .75 \\
Psycho-physical State & .87 \\
Relationships & .82 \\
Motivation & .74 \\
Accomplishment & .81 \\
Time & .79 \\
Total ARPI & .92 \\
\hline
\end{tabular}

Subscale Intercorrelations of the ARPI. The coefficients of correlation of each subscale with each of the other subscales were calculated and are presented in Table LXIV in order to show the relationship between the pairs of subscales and between the individual subscales and the Total ARPI scale.

The subscale intercorrelations ranged from .21 (Expectation with Relationships) to .68 (Motivation with Accomplishment), excluding the Time subscale. The Time subscale is composed of items from the other five subscales. Also, the correlations between the subscales and the Total ARPI scale are predictably higher, since the Total ARPI scale is comprised of items from all of the other six subscales.

Reproduced with permission of the copyright owner. Further reproduction prohibited without permission. 
TABLE LXIV

ARPI SUBSCALE INTERCORRELATIONS

\begin{tabular}{|c|c|c|c|c|c|c|c|c|}
\hline & Exp & Mot & P S & $\operatorname{Re} 1$ & $A c c$ & Time & Tot & ARPI \\
\hline Expectation & & .35 & .65 & .21 & .30 & .52 & & .70 \\
\hline Motivation & & & .62 & .36 & .68 & .68 & & .79 \\
\hline Psycho-physical & & & & .35 & .53 & .80 & & .87 \\
\hline Relationships & & & & & .55 & .64 & & .62 \\
\hline Accomplishment & & & & & & .68 & & .78 \\
\hline Time & & & & & & & & .88 \\
\hline
\end{tabular}

Validity of ARPI. The construct validity of the Administrator Role Perception Inventory is reported thoroughly in Wax (1983). Therefore, the validity discussion in this chapter focuses upon the correlations calculated between the respondents' self-perceptions of job stress, self-perceptions of personal stress and self-perceptions of burnout and their Total ARPI score; that is, the discussion focuses upon the criterion-related validity of the Total ARPI.

Criterion-related validity of the Total ARPI was calculated by computing the Coefficient of Correlation of the three variables of job stress, personal stress and burnout with the Total ARPI score. Respondents were asked on the Job Data sheet to rate their job stress and personal stress in two separate questions by marking from zero to

Reproduced with permission of the copyright owner. Further reproduction prohibited without permission. 
eight. Similarly, respondents were asked on the Job Data sheet to indicate their current level of burnout. Respondents were asked the questions, "How much stress is in your work?" and "How much stress do you feel?" They were to mark on a Likert-type scale for each stress question a number from zero to eight, indicating no stress to tremendous stress. The word "some" was written under the number two; "moderate" was written under the number four, and "considerable" was written under the number six. For scoring and

TABLE LXV

FREQUENCY DISTRIBUTION OF SCORES ON JOB STRESS

\begin{tabular}{lcccc}
\hline Category & Score & Frequency & Percent & $\begin{array}{c}\text { Cumulative } \\
\text { Percent }\end{array}$ \\
\hline Tremendous & 9 & 28 & 7.2 & 100.0 \\
Considerable & 7 & 66 & 17.0 & 92.8 \\
Moderate & 6 & 156 & 40.2 & 75.7 \\
& 5 & 50 & 12.9 & 35.4 \\
Some & 4 & 51 & 13.1 & 22.5 \\
& 3 & 10 & 2.6 & 9.3 \\
None & 2 & 24 & 6.2 & 6.7 \\
No Response & 1 & 1 & 0.3 & 0.5 \\
\hline TOTAL & & 1 & 0.3 & 0.3 \\
\hline
\end{tabular}

Reproduced with permission of the copyright owner. Further reproduction prohibited without permission. 
computer analyses, the scores were converted to a one to nine scale. Table LXV provides the frequency distribution for the job stress question. The mean for the job stress question was 6.57 , indicating moderate to considerable job stress. The standard deviation was 1.5. The median was 6.8 , with a mode of 7.0 .

Table LXVI presents the frequency distribution for the personal stress question. The mean for the personal stress question was 5.65 , indicating moderate personal stress. The TABLE LXVI

FREQUENCY DISTRIBUTION OF SCORES ON PERSONAL STRESS

\begin{tabular}{lcccc}
\hline Category & Score & Frequency & Percent & $\begin{array}{c}\text { Cumulative } \\
\text { Percent }\end{array}$ \\
\hline Tremendous & 9 & 11 & 2.8 & 100.0 \\
Considerable & 8 & 32 & 8.2 & 97.2 \\
Moderate & 6 & 92 & 23.7 & 88.9 \\
& 5 & 75 & 19.3 & 65.1 \\
Some & 4 & 95 & 24.5 & 45.7 \\
& 3 & 20 & 5.2 & 21.2 \\
None & 2 & 58 & 14.9 & 16.0 \\
No Response & 1 & 4 & 1.0 & 1.0 \\
\hline TOTAL & & 0 & 0.3 & 0 \\
\hline
\end{tabular}

Reproduced with permission of the copyright owner. Further reproduction prohibited without permission. 
standard deviation was 1.6 , and the median was 5.7, indicating a generally symmetrical distribution. The mode was 5.0 .

Coefficients of correlation were calculated for the job stress question, personal stress question and the Total ARPI scale. These coefficients of correlation were significant at the .001 level. Table LXVII provides the coefficients of correlation between the Total ARPI scale and the two stress questions. Since the higher scores on the ARPI indicate "healthier," less burned-out perceptions, correlations with the stress questions are negative.

\section{TABLE LXVII}

CORRELATIONS BETWEEN STRESS MEASURES AND TOTAL ARPI SCALE

Stress Question

Correlation

$\begin{array}{lc}\text { Job Stress } & -.28 \% \\ \text { Personal Stress } & -.50 \%\end{array}$

*Significant at the .001 Jevel

Respondents were asked on the Job Data form to "Please indicate your current level of burnout." They were to mark on a Likert-type scale a number from zero to eight, indicating no burnout to tremendous burnout, respectively. Beneath the number two the word "some" appeared. "Moderate" appeared under number four, and "considerable" was written under the number six. The scores were converted to a one to 
nine scale for computer analyses. The mean and median for

the burnout question were 4.2 , indicating some to moderate burnout and a symmetrical distributio. The standard deviation was 2.0. The mode was 3.0. Tade LXVIII provides the frequency distribution of the burnout question responses.

TABLE LXVIII

FREQUENCY DISTRIBUTION OF SCORES ON BURNOUT

\begin{tabular}{lcccc}
\hline Category & Score & Frequency & Percent & $\begin{array}{c}\text { Cumulative } \\
\text { Percent }\end{array}$ \\
\hline Tremendous & 9 & 6 & 1.5 & 100.0 \\
Considerable & 8 & 16 & 4.1 & 98.4 \\
& 7 & 39 & 10.1 & 94.3 \\
Moderate & 6 & 40 & 10.3 & 84.1 \\
& 5 & 81 & 20.9 & 73.7 \\
Some & 4 & 36 & 9.3 & 52.6 \\
& 3 & 81 & 20.9 & 43.2 \\
None & 2 & 47 & 12.1 & 22.1 \\
No Response & 1 & 38 & 9.8 & 9.9 \\
\hline TOTAL & & 4 & 1.0 & 1.0 \\
\hline
\end{tabular}

The coefficient of correlation was calculated between the burnout question responses and the Total ARPI scale. The results indicated the coefficient of correlation was -.54 ,

Reproduced with permission of the copyright owner. Further reproduction prohibited without permission. 
which is significant at the .001 level. The correlation is negative, since higher scores on the ARPI reflect less burned-out perceptions.

\section{$\underline{\text { Summary }}$}

The reliability of the ARPI proved satisfactory. The reliability coefficients (alpha) for the subscales ranged from .74 for the Motivation subscale to .87 for the subscale of Psycho-physical State. Coefficient Alpha for the Total ARPI scale was .92 .

Respondents scored higher on the job stress question than on the personal stress or burnout questions. The mean for the job stress question was 6.57 , indicating moderate to considerable job stress. The mean of 5.65 for the personal stress question indicated respondents perceived moderate personal stress. The mean of 4.2 for the burnout question indicated respondents perceived "some" to "moderate" burnout.

The construct validity of the ARPI previously had been reported by Wax (1983). Measures of criterion-related validity, using the variables of job stress, personal stress and burnout were analyzed for this research. The results indicated satisfactory correlations between respondents' selfperceptions of job stress, personal stress and burnout with their Total ARPI score. The distributions were found to be generally symmetrical.

Reproduced with permission of the copyright owner. Further reproduction prohibited without permission. 


\title{
CHAPTER V \\ SUMMARY, CONCLUSIONS AND RECOMMENDATIONS
}

\begin{abstract}
The purpose, procedures and results of this investigation are reported in this chapter. Also, conclusions, limitations and recommendations are addressed.
\end{abstract}

\section{$\underline{\text { Summary }}$}

The purpose of this research was to indentify the work values of public school administrators, as measured by the Ohio Work Values Inventory, and determine the relationships between public school administrator role perceptions associated with burnout, as measured by the Administrator Role Perception Inventory, and their work values. The data were analyzed by:

a) Levels of Administration

b) Background Data of Administrator

c) Specific Scales on the Instruments

The administrators from 10 urban and suburban school districts in Oregon and Washington received a packet containing a biographical data sheet, an Ohio Work Values Inventory and an Administrator Role Perception Inventory in the Spring of 1983. Of the 701 administrators receiving materials, 388 administrators completed packets.

Reproduced with permission of the copyright owner. Further reproduction prohibited without permission. 
Analysis of the data revealed the sample for this research consisted primarily of line administrators with job responsibilities at the building levels of high school, middle school/junior high school or elementary school. The majority of the administrators had been in their present position four years or less. The average administrator in the sample was a 46-year-old male with a Master's Degree and a Standard Administrative certificate.

Respondents scored the highest on the Accomplishment and Relationship subscales of the Administrator Role Perception Inventory, with means of 40.19 and 39.44 , respectively. The administrators scored the lowest on the Expectation subscale of the ARPI, with a mean of 29.30 . The Total ARPI scale mean was 179.03, out of a possible 290. Higher scores on the ARPI reflect "healthier," less burnedout perceptions.

The reliability of the ARPI was satisfactory, with coefficients ranging from .74 for the subscale of Motivation to .92 for the Total ARPI scale. Criterion-related validity, as measured by correlations between the job stress, personal stress and burnout questions, proved satisfactory, also. The correlations were significant at the .001 level.

The administrators indicated moderate to considerable job stress (mean of 6.57), moderate personal stress (mean of 5.65 ) and some to moderate burnout (mean of 4.2 ).

Reproduced with permission of the copyright owner. Further reproduction prohibited without permission. 
Administrators in the sample assigned the greatest importance to the work value of Task Satisfaction, with a mean of 32.31 , and the least importance to the work value of Solitude, with a mean of 14.96 , as measured by the Ohio Work Values Inventory. The work value of Self-realization was valued in the "considerable" to "great" range of values. Considerable importance was assigned to the work values of Altruism, Independence and Ideas/Data; and moderate to considerable importance was assigned to the work values of Control and Money. Finally, respondents assigned moderate importance to the work values of Security, Prestige and Object Orientation.

The reliability and validity of the Ohio Work Values Inventory proved satisfactory. Reliability coefficients ranged from .84 for the Independence scale to .95 for the scale of Money. Scale intercorrelations ranged from $\quad .64$ (Self-realization with Task Satisfaction) to -.18 (Altruism with Solitude).

Statistically significant positive correlations were found between the age of the administrator with the ARPI subscales of Expectation and Psycho-physical State. The degree of the administrator was positively correlated with the Relationship subscale. Statistically significant negative correlations were found between the ARPI subscales of Motivation and Accomplishment with the total number of years an administrator held the same job at the same location and

Reproduced with permission of the copyright owner. Further reproduction prohibited without permission. 
between the ARPI subscale of Motivation and the total number of years an individual had been an educational administrator.

Statistically significant negative correlations were found between the age of the administrator with the OWVI scales of Self-realization and Prestige, between the years an administrator had held the same job at the same location with the Ideas/Data scale and between the total number of years an individual had been an educational administrator with the Self-realization and Ideas/Data scales. Statistically significant positive correlations were found between the years an administrator held the same job at the same location with the OWVI scales of Object Orientation and Security.

Many of the OWVI scales were correlated statistically significantly at the .05 level or above with the ARPI subscales and/or the Total ARPI scale. There were 35 statistically significant correlations between OWVI scales and ARPI subscales and the Total ARPI scale, the majority of the correlations being at the .001 level of significance.

The analyses of variance indicated no statistically significant differences between male and female administrators on all measures of burnout. That is, there were no statistically significant differences found between male and female administrators on all subscales of the ARPI and on

Reproduced with permission of the copyright owner. Further reproduction prohibited without permission. 
the Total ARPI scale. Similarly, there were no statistically significant differences between male and female administrators on nine of the 11 work values measured by the OWVI. Women administrators assigned statistically significantly more importance to the work values of Self-realization and Ideas/Data Orientation.

Also, analyses of variance indicated there were differences in three work values and two burnout subscales between different levels of administration. Central office administrators assigned statistically significantly more importance to the work values of Independence and Prestige and less importance to Altruism than did elementary school administrators. Central office administrators valued Relationships, an ARPI subscale, less than did all levels of building administrators. Central office administrators were more likely to view the past as better than the present than elementary school administrators, a perception measured by the ARPI Time subscale.

\section{Conclusions}

The review of the literature suggested burnout was a subtle pattern of symptoms unique to each individual, more appropriately assessed in terms of the degree of burnout one was experiencing, instead of an either-or classification system of "burned-out" or "not burned-out." Also, some possible relationships between an individual's work values 
and burnout, between the sex of the respondent and the individual's work values and between the individual's place in the organizational heirarchy and burnout were suggested by the literature. Additionally, the review of the literature indicated members of a vocation may have similar work values, and burnout could be one of the factors negatively affecting our public schools. These issues will be addressed in the conclusions of this investigation.

The Degree of Burnout in the Sample's Administrators

The administrators in this sample reported moderate to considerable job stress, moderate personal stress and some to moderate burnout on the biographical Data Sheet. The moderate burnout perception was reinforced by the mean for the Total ARPI scale, which also indicated moderate burnout of the administrators in the sample. The coefficient of correlation between the burnout question on the biographical Data Sheet and the Total ARPI scale was -.54, significant at the .001 level. The correlation is negative, since higher ARPI scores indicate less burned-out, "healthier" perceptions. This suggests that although the job of an administrator can be considerably stressful, the administrators in this sample were coping adequately with the stress at the time of this research. In fact, the degree of burnout was less than that reported by Wax (1983), who researched administrative burnout during a time of year thought to be much less stressful than that employed in the

Reproduced with permission of the copyright owner. Further reproduction prohibited without permission. 
current research. Considering the time of year this research was conducted, administrators appeared to be coping adequately with the stressors commonly associated with the end of the school year.

\section{Burnout of Administrators in Future Not Predicted}

The review of the literature suggested individuals who highly valued Prestige, Self-realization, Task Satisfaction and Altruism may be more prone to future burnout. Although administrators in this sample placed considerable importance upon those work values, that is not enough to predict their future burnout. The total years an individual had been doing the same job at the same location and the total number of years of being an educational administrator were not statistically significantly correlated with the Total ARPI scale measuring burnout, although the correlations of those biographical descriptors with the Total ARPI scale were negative. It is evident from the two notable comments in Appendix D that many factors influence the burnout level of administrators over a period of time.

Relationships Between Work Values and Burnout

The profile of an individual experiencing burnout indicated by the literature review suggested a withdrawal from other individuals, a desire to work in relative solitude, and a lack of feeling of accomplishment and motivation. Also, individuals experiencing burnout might

Reproduced with permission of the copyright owner. Further reproduction prohibited without permission. 
think their job was going to be different than reality proved it to be. Since the administrators in this sample were experiencing only a moderate degree of burnout, one would expect their scale means on the Relationship, Accomplishment and Motivation subscales of the ARPI to be higher and their scale means for the Expectation subscale to be lower. This was, in fact, true for the sample. The highest means on the ARPI subscales were for Relationships and Accomplishment, and the lowest mean was for the Expectation subscale.

Similarly, individuals experiencing burnout would be expected to have a high scale mean for the work value of Solitude on the OWVI and have lower means for the scales of Task Satisfaction, Self-realization and Altruism. Again, since the administrators in this sample were experiencing only moderate burnout, the Solitude scale mean was the lowest, and the scale means for the work values of Task Satisfaction, Self-realization and Altruism were higher. The literature suggested that individuals who place high value on Altruism, Task Satisfaction and Selfrealization are more likely eventually to experience burnout than are individuals who place lesser importance on these values. The importance placed by administrators on these values may partially explain the moderate burnout which they indicated. Since the role of an educator is perceived as altruistic and educators have encouraged students and each 
other to strive for self-realization, it is reasonable to expect those who have "healthier" profiles on the ARPI to place greater personal importance on these values than those who have less "healthy" profiles; in fact, a lowering of these values may accompany an increase in feelings of burnout. The positive correlations of Altruism, Selfrealization and Task Satisfaction with the subscales and Total scale of the ARPI (Table XLV) lends support to this supposition. Finally, one would expect individuals in a "helping" profession to place little importance nn Solitude in the job setting. The literature indicates that withdrawal from interactions with others is a symptom of burnout. As to be expected, the administrators placed little value on Solitude, but the negative correlations between this variable and the subscales and Total scale of the ARPI indicate that those people with a "less healthy" profile on the ARPI place greater value on Solitude.

In total, there were 35 statistically significant correlations between the OWVI scales and the ARPI subscales and the Total ARPI scale, indicating there are statistically significant relationships between administrator work values and role perceptions associated with burnout. Every work value, except the scale of Money was statistically significantly correlated with at least one subscale on the ARPI.

Work Values and the Sex of the Administrator

Previous research findings have indicated differences

Reproduced with permission of the copyright owner. Further reproduction prohibited without permission. 
in work values of male and females appear at an early age (Hales and Fenner, 1973; Hales and Yackee, 1974), and the number and magnitude of the differences in the work values between males and females increase with the age of the subjects (Hales and Hartman, 1978). However, only two significant differences of a possible 11 work values were identified in this present study, supporting Holland's (1973) assumption. Sex differences in work values within a somewhat homogeneous subset of a profession may be small. School districts can assume their male and female administrators in this sample generally have similar work values.

\section{Burnout and the Sex of the Administrator}

There were no statistically significant differences found between male and female administrators on the burnout measures. School districts in the sample can expect their male and female administrators to reflect similar degrees of burnout. Women administrators should not be rejected because of a false assumption that they are more likely to burn out.

Work Values and the Level of Administration

Central office administrators varied statistically. significantly from elementary school administrators on three key work values. Central office administrators assigned statistically significantly more importance to Independence and Prestige and statistically significantly less importance

Reproduced with permission of the copyright owner. Further reproduction prohibited without permission. 
to Altruism than elementary school administrators. Additionally, central office administrators varied statistically significantly from middle school/junior high school and high school administrators with central office administrators assigning statistically more importance to Independence than the aforementioned other administrators. School districts may want to consider central office administrators a distinct subset of administrators, valuing the opportunity to be more independent from close supervision and valuing opportunities for more personal recognition for work performed.

Burnout and the Level of Administration

Central office administrators differed from all other levels of administration on the ARPI subscale of Relationships, assigning statistically significantly less importance to Relationships than other school administrators. This could be due to central office administrators performing their duties with less contacts with colleagues, parents and students. Many of the questions for this subscale referred to contacts with colleagues, parents and students.

There were no statistically significant differences between the levels of administration and the Total ARPI scale, indicating all levels of administration in the sample experienced similar burnout. No level of administration experienced significantly greater burnout. The literature 
on stress stated individuals higher in the organizational hierarchy are subject to more stress. It is evident from the data in this investigation that administrators at the building levels and in the central office respond to stressors similarly in terms of experiencing burnout.

\section{Satisfaction of Lower Order Needs}

Hackman and Lawler (1971) stated that most lower order needs, such as the need for security, are reasonably wellsatisfied in contemporary society. Administrators valued Security only moderately, with a mean of 22.20 , suggesting that the lower order need of Security may be reasonably satisfied for the administrators in this sample. Also, Centers had stated that the middle class desired jobs offering self-expression, while the working class desired jobs offering security. If one considers administrators members of the middle class, Centers assumption was supported.

\section{Importance of Money to Administrators}

The scale mean for the work value of Money was 23.38, indicating respondents assigned moderate to considerable importance to this value. However, it was valued much less than the higher order needs of Self-realization and Altruism. Sheppard and Herrick (1972) suggested that overall job satisfaction was more highly correlated with opportunity for personal growth and interesting work than pay. It would appear, then, that the school districts in this

Reproduced with permission of the copyright owner. Further reproduction prohibited without permission. 
sample could affect the job satisfaction of their administrators more with attention paid to the tasks assigned the administrators than with the amount of their paycheck. Hackman and Lawler's (1971) research support this finding; also the results have implications for those of the scientific management persuasion who "have tended to assume that the typical employee will be content, if paid judiciously for his cooperation, to work jobs which provide little or no opportunity for personal feelings of accomplishmen, or achievement" (p. 280). Since the mode for this scale was 35, the highest score possible, school districts in the sample can be assured that Money was of great importance to a small group of administrators. However, the scale of Money was not significantly correlated with any of the ARPI subscales nor with the Total ARPI scale, indicating administrative burnout is not related to the importance individuals assigned to Money.

\section{Age of Administrator and Work Values}

The age of the administrator was statistically significantly negatively correlated at the.01 level with the work values of Self-realization and Prestige. It would appear Prestige and Self-realization may become less important to an administrator as the administrator grows older.

Time on Job and Work Values

The work values of Self-realization and Ideas/Data were

Reproduced with permission of the copyright owner. Further reproduction prohibited without permission. 
statistically significantly negatively correlated with the total number of years an individual was an administrator, suggesting these work values may become less important the longer an individual was an educational administrator.

In contrast, the work value of Security was positively correlated with the total number of years an administrator held the same job at the same location, suggesting the less mobile an administrator is, the more important Security is to the administrator.

\section{ARPI Subscale Correlations with Biographical Data}

The ARPI subscale of Motivation was statistically significantly negatively correlated with the total number of years an individual had been an educational administrator, suggesting Motivation may decrease the longer an individual is an administrator.

There was a statistically significant negative correlation with the age of the administrator and the subscale of Psycho-physical State, suggesting emotional and physical vigor may decrease with the age of the administrator.

An administrator's feelings of accomplishment, as measured by the ARPI subscale of Accomplishment, were statistically significantly negatively correlated with the number of years an individual had been at the same job in the same location, suggesting, individuals who have been in a job a longer period of time may feel they have accomplished less of their professional goals.

Reproduced with permission of the copyright owner. Further reproduction prohibited without permission. 
The statistically significant positive correlation between the Relationships subscale of the ARPI and the academic degree of the administrator indicated administrators with higher degrees more strongly desired relationships with colleagues and clients.

\section{Comparison of Data with Previous Findings}

Comparisons of the means and standard deviations for the ARPI subscales and the Total ARPI scale for this research with the means and standard deviations reported by Wax (1983) reflected a similarity between the data for the two studies. The Administrator Role Perception Inventory appears to be relatively stable over time, independent of job stress fluctuations over a period of a year.

Use of OWVI and ARPI with Administrators

Examination of reliability and validity measures of the two instruments employed in the research to measure work values (OWVI) and role perceptions associated with burnout (ARPI) indicated both instruments have satisfactory reliability and validity for this sample population. The reliability measures were comparable to other self-report inventories using Likert-type scales. In fact, the majority of self-report inventories have reliabilities below. 90 , and many of the reliabilities reported are below . 80 (Nunnally, 1972 )

The ARPI subscale intercorrelations reinforce Wax's

Reproduced with permission of the copyright owner. Further reproduction prohibited without permission. 
conclusion the ARPI should be used as an entire scale, due to the interrelatedness of the subscales. The subscales of the ARPI should be viewed as several of the many facets of burnout.

\section{Practical Significance of Findings}

All statistical tests take sample size into account. Statistically significant values in large samples, then, are as real as those found in small samples, and an increase in the size of the sample increases the reliability or precision of estimates of population parameters.

In considering the practical significance of the data for this study, one must consider the sample size, the magnitude of the correlations and the magnitude of the differences between group meansin the analyses of variance. When interpretating data from large samples, minute differences can be statistically significant.

Many of the statistically significant correlations reported did not account for an appreciable amount of variance and may be of little use in predicting or anticipating how administrators react over time. Similarly, many of the absolute differences between group means on statistically significant analyses of variance were small. The statistically significant correlations which were of the smallest magnitude were between the biographical data and the OWVI scales and ARPI subscales and Total ARPI scale. These correlations should be viewed the most cautiously. 
Larger correlations were found between the OWVI scales and the ARPI subscales and Total ARPI scale, accounting for a larger amount of the variance.

\section{Limitations of the Study}

The limitations of this study include the geographic location of the sample, differences in job descriptions and job responsibilities of administrators and the return rate.

\section{Geographic Location}

Administrators in ten school districts from Oregon and Washington were included in the sample. It is not known whether administrators in other states or geographical regions of Oregon and Washington possess characteristics that would cause them to be classified as a different population.

Job Responsibility Differences

Job responsibilities and personal interactions differ, although administrators may have similar job titles. It is possible the duties of an administrator in large urban school districts may be different from those in smaller suburban districts though they possess the same job title.

\section{$\underline{\text { Return Rate }}$}

The overall return rate for this study is what is traditionally expected in similar studies utilizing a questionnaire. The return rate was lower for the urban respon- 
dents than for the suburban respondents, as generally is the case. It is possible that those who did not provide data for this study have different work values and role perceptions than those administrators who chose to participate in this research.

\section{Implications for School Districts}

The purpose of this research was to identify the work values of public school administrators and determine the relationships between public school administrator role perceptions associated with burnout and their work values. This investigation has suggested some implications for school districts.

1. The lack of statistically significant differences between the sexes on burnout and nine of 11 work values indicated male and female administrators have similar work values and may be expected to experience similar burnout when subjected to comparable stress factors. This finding supports the programs of school districts to have more women in administration.

2. The low importance assigned to the work value of Solitude suggests districts should, for the most part, endeavor to structure administrative jobs without a high degree of solitude. A support system or a system of networking among administrators would help to cut down isolation among administrators. Similarly, districts interested

Reproduced with permission of the copyright owner. Further reproduction prohibited without permission. 
in the satisfaction of the administrative staffs should take note of the great importance placed on the values of Task Satisfaction, Ideas/Data and Altruism, suggesting districts may want to structure administrative jobs allowing for the pursuit of those values. These findings give support to the job enlargement theories. It is apparent administrators seek more from their jobs than an adequate paycheck.

3. The school district inservice programs for administrators may want to focus on stress and burnout reduction. Although the administrators responding in this sample did not report a high degree of burnout, it is evident they were under a lot of stress. Some districts may be interested in reducing the current stress and burnout levels on the assumption even moderate stress and burnout is too high and is detrimental to education.

\section{Recommendations for Further Research}

The data from this research suggested administrators in this sample were coping adequately with moderate to considerable job stress at a particularly stressful time of the year. However, no data were collected on absenteeism rates to indicate whether administrator absenteeism was higher during the Spring when there is assumed to be more stress.

The administrative turnover rates may be another direction for further research. One does not know whether the administrators reflected a lower degree of burnout,

Reproduced with permission of the copyright owner. Further reproduction prohibited without permission. 
since all those who were experiencing higher degrees of burnout may have left the profession before the survey.

A longitudinal study over time assessing work values and burnout of entry-level administrators and the work values and burnout of administrators throughout their careers would indicate whether there are changes over time. 
BIBLIOGRAPHY

Reproduced with permission of the copyright owner. Further reproduction prohibited without permission. 
Austin, M., Babcock, N., Eddy, D., Flagler, C., Ford, D., McNally, T., Thomson, M., Vanden Berg, C., \& Reid, K. An exploratory study of the burnout syndrome in the social work profession. School of Social Work, Western Michigan University: Kalamazoo, Spring, 1977.

Baird, L. L. The relation of vocational interests to life goals, self-ratings of ability and personality traits, and potential for achievement. Journal of Counseling Psychology, 1970, 17, 233-239.

Beier, E. G. The effect of induced anxiety on flexibility of intellectual functioning. Psychological Monographs, 1951 , 65, (whole No. 326).

Bergstrom, B. Psychomotor performance under stress: Studies of human tracking behavior under short-term psychological stress. MPI Report, 1970, 04.22:6.

Bloch, A. M. Combat neurosis in inner city schools. American Journal of Psychiatry, 1978, 135, 1189-1192.

Bordin, E. S. A theory of interests as dynamic phenomena. Educational and Psychological Measurement, $1943, \underline{3}, 49-$ 66 .

Bowers, D. G., \& Franklin, J. L. American work values and preferences. Michigan Business Review, 1977, 29, 1422 .

Brayfield, A. H., \& Crockett, W. H. Employee attitudes and employee performance. Psychological Bulletin, 1955, $\underline{52}, 396-424$.

Brightman, E. S. An introduction to philosophy. New York: Henry Holt, $19 \overline{25}$.

Buchholz, R. The belief structure of managers relative to work concepts measured by a factor analytic model. Personnel Psychology, 1977, 30, 567-587.

Buck, V. E. Working under pressure. New York: Crane, Russak \& Company, 1972.

Reproduced with permission of the copyright owner. Further reproduction prohibited without permission. 
Campbe11, D. P. Handbook for the Strong Vocational Interest Blank. California: Stanford University Press, $\frac{\text { Sig71. }}{191}$

Centers, R. Motivational aspects of occupational stratification. Journal of Social Psychology, 1948, 28, 187217 .

Centers, R. The psychology of social classes. Princeton, New Jersey: Princeton University Press, 1949.

Chance, P. That drained-out, used up feeling. Psychology Today, $1981, \underline{15}, 88-89$.

Chaney, R. Vocational values of children as they relate to economic community grade level, sex and parental occupational level. (Doctoral disseration, Ohio University, 1968). Dissertation Abstracts International,

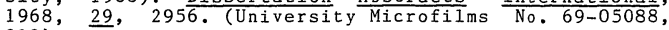
213)

Cherniss, C. Recent research and theory on job stress and burnout in helping professions. Paper presented in Grand Rapids, Michigan, May, 1978.

Clark, D. L., Lotto, L. S., \& McCarthy, M. M. Factors associated with success in urban elementary schools. Phi Delta Kappan, 1980, 61, 467-470.

Coch, L., \& French, J. R., Jr. Overcoming resistance to change. Human Relations, 1948,1 , 512-532.

Cofer, C. N., \& Appley, M. H. Motivation: Theory and research. New York: Wiley, $196 \overline{4}$

Combs, A. W., \& Snygg, D. Individual behavior. New York: Harper and Row, 1959.

Cooper, C. L. The stress check. Englewood Cliffs: Prentice-Hail, 1981 .

Crutchfield, R. S., Woodworth, D. G. and Albrecht, R. E. Perceptual performance and the effective person. Personnel Laboratory, U. S. Air Force, ASTIA Document No. AD 151 039. Lackland Air Force Base, Texas, 1958.

Darley, J. G., \& Hagenah, T. Vocational interest measurement. Minneapolis: University of Minnesota Press, 1955 .

Editorial Research Reports. The American work ethic. Washington: Congressional Quarterly, 1973.

Reproduced with permission of the copyright owner. Further reproduction prohibited without permission. 
Edmonds, R. Effective schools for the urban poor. Educational Leadership, 1979, 37, 15-24.

Fenner, B. J. The development of the Ohio Work Values Inventory: An investigation of internal characteris tics. (Doctoral dissertation, Ohio University, 1972). Dissertation Abstracts International, 1972, 33, 1433. (University Microfilms No. 72-26, 366, 183)

Fenner, B. J., \& Hales, L. W. Measuring the work values of elementary school children. A paper presented at the annual meeting of the American Educational Research Association, New Orleans, 1973.

Florida State Department of Education. A guide: Teaching moral and spiritual values in Florida schools. Bulletin 14-1962. Tallahassee: The Department, 1962.

Freudenberger, H. J. Staff burn-out. Journal of Social Issues, $1974, \underline{30}, 159-165$.

Freudenberger, H. J. The staff burn-out syndrome in alternative institutions. Psychotherapy Theory, Research and Practice, 1975, 12, 73-82.

Freudenberger, H. J. Burn-out: Occupational hazard for the child care worker. Child Care Quarterly, 1977, 6, 9099.

Freudenberger, H. J., \& Richelson, G. Burn out: the high cost of high achievement. New York: Bantam Books, 1980 .

Gann, M. L. The role of personality factors and job characteristics in burnout: A study of social service workers. (Doctoral dissertation, University of California, Berkeley, 1979). Dissertation Abstracts International, $1979,40,336 \overline{6 \text {. (University Microfilms No. }}$ DEM80-00351, 150)

Garcia, A. S. Predictors of job satisfaction and worker burnout among child welfare workers. (Doctoral dissertation, University of Texas at Austin, 1980). Dissertation Abstracts International, 1981, 41, 4839 A (University Microfilms No. 81-09166, 271)

Gentile, L. M., \& McMillan, M. M. Combating burnout: a must for secondary urban reading teachers. Reading Wor 1d, $1980, \underline{19}, 332-337$.

Gherman, E. M. Stress and the bottom line. New York: AMACON, 1981 . 
Ginzberg, E., Ginsburg, S. W., Axe1rod, S., \& Herma, J. C. Occupational choice: An approach to a general theory. New York: Columbia University Press, 1951 .

Gmelch, W. H. Beyond stress to effective management. Oregon School Study Council Bulletin, 20, Eugene, Oregon: University of Oregon, 1977.

Gmelch, W. H., \& Swent, B. Stress at the desk and how to cope effectively. Oregon School Study Council Bulletin, 21, Eugene, Oregon: University of Oregon, 1977.

Gooding, J. The job revolution. New York: Walker, 1972.

Gove, F. B. Webster's third new international dictionary of the English language, unabridged. Springfield, Mass., 1961 .

Grace, J. C. Work values of community college students: An exploratory investigation of freshman at Middlesex Community College, Bradford, Mass. (Doctoral dissertation Boston College, 1974). Disseration Abstracts International, 1974, 35, 1977. (University Microfilms No. DCJ74-20703, 163)

Greenwood, J. W. III, \& Greenwood, J. W., Jr. Managing executive stress. New York: Wiley, 1979.

Hackman, J. R., \& Lawler, E. Employee reactions to job characteristics. Journal of Applied Psychology, 1971, 55, 259-286.

Hales, A. K. A comparative study of the work values of nurses versus the values of nurse trainees. Masters Thesis, Ohio University, 1977.

Hales, L. W., \& Fenner, B. J. Work values of $5 \mathrm{th}, 8 \mathrm{th}$ and 11 th grade students. Vocational Guidance Quarterly, 1972 , 20, 60-66.

Hales, L. W., \& Fenner, B. J. Ohio Work Vaiues Inventory. Ohio. 1973.

Hales, L. W., \& Fenner, B. J. Sex and social class differences in work values. Elementary School Guidance and Counseling, $1973, \underline{8}, 26-32$.

Hales, L. W., \& Hartman, T. P. Measuring the work values of technical college students: the Ohio Work Values Inventory. Unpublished paper, Ohio University, 1977.

Reproduced with permission of the copyright owner. Further reproduction prohibited without permission. 
Hales, L. W., \& Hartman, T. P. Personality, sex and work values. Journal of Experimental Education, 1978, 47, $16-21$.

Hales, L. W., \& Yackee, K. Self-concepts, sex, and work values. A paper presented at the annual meeting of the American Educational Research Association, Chicago, Apri1 15-19, 1974.

Hales, L. W., \& Wax, A. S. Administrator Role Perception Inventory. Oregon, 1982.

Hammond, M. Motives related to vocational choices of college freshmen. Journal of Counseling Psychology, $1956, \underline{19}, 257-261$.

Herzberg, F., Mausner, B., \& Snyderman, B. Job attitudes: Review of research and opinion. Pittsburg: Psychology Service of Pittsburgh, 1957 .

Herzberg, F., Mausner, B., \& Snyderman, B. The motivation to work, 2d ed. New York: Wiley, 1959 .

Hinkle, L. E. The concept of 'stress' in biological and social sciences. Science, Medicine and Man, 1973, 1 , 43.

Holland, J. L. Manual for the Vocational Preference Inventory: Palo Alto: Counsulting Psychologists Press, 1958 .

Holland, J. L. Explorations of a theory of vocational choice and achievement: II. A four-year prediction study. Psychological Reports, 1963, 12, 537-594.

Holland, J. L. Manual for the Vocational Preference Inventory. Palo Alto: Consulting Psychologists Press, 1965 .

Holland, J. L. The psychology of vocational choice: A theory of personality types and model environments. Waltham: B 1 aisdel1, 1966 .

Holland, J. L. Making vocational choices. Englewood Cliffs: Prentice-Hal1, 1973.

Horney, K. Our inner conflicts. New York: Norton, 1945.

Howard, N. How good is values analysis? Dun's Review, 1981, 117, $118-120,123$.

Reproduced with permission of the copyright owner. Further reproduction prohibited without permission. 
Kahn, R. L. Job burnout: Prevention and remedies. Public Welfare, $1978, \underline{36}, 61-63$.

Katz, M. Decisions and values. New York: College Entrance Board, 1963 .

Kenton, L. Stress. Unilever Magazine, 1974, 9 .

Klampe, C. The work values of secondary teachers: A comparative study by teaching assignment. Masters Thesis, Portland State University, 1983.

Kornhauser, A. Mental health of the industrial worker. New York: Wiley, 1965 .

Lawler, E. E., \& Porter, L. W. Antecedent attitudes of effective managerial performance. Organizational Behavior and Human Performance, 1967, $2,122-142$.

Lazarus, R. S., Deese, J., \& Osler, S. F. Effects of psychological stress upon performance. Psychological Bulletin, 1952, 49, 293-317.

Leeson, B. S. Professional burnout: The effect of the discrepancy between expectation and attainment in social workers in a mental hospital. (Doctoral dissertation, University of Michigan, 1980). Dissertation Abstracts Internationa $1, \underline{1980}, \underline{41}, \frac{1}{3953 \mathrm{~A} .}$ (University Microfilms No. 81-06177, 243)

Levinson, H. When executives burnout. Harvard Business keview, 1981, 59, 72-81.

Lipovenko, D. The 'burnout' syndrome. World Press Review, $1981, \underline{28}, 60$.

Lewin, K., Lippit, R., \& White, R. K. Patterns of aggressive behavior in experimentally created 'social climates'. Journal of Social Psychology, 1939, 10, $271-$ 299.

Margolis, B., \& Kroes, W. Occupational stress and strain. In A. McLean (Ed.) Occupational stress. Springfield: Charles C. Thomas, 1974 .

Maslach, C. Burnout. Human Behavior, 1976, ㅌ, 16-22.

Maslach, C. Job burnout. How people cope. Public Welfare, $1978, \underline{36}, 56-58$. 
Maslach, C. The burn-out syndrome and patient care. In Garfield C. (Ed.), Stress and survival: The emotional realities of life-threatening illness. St. Louis: Mosby, 1979 .

Maslach, C., \& Jackson, S. E. Lawyer burn-out. Barrister, $1978, \underline{5}(2), 52-54$.

Maslach, C., \& Jackson, S. E. Burned-out cops and their families. Psychology Today, 1979, 12, 59-62.

Maslach, C., \& Jackson, S. E. The measurement of experienced burnout. Journal of Occupational Behavior, 1981,2 , 99-113.

Maslach, C., \& Pines, A. The burn-out syndrome in the day care setting. Child Care Quarterly, 1977, 6, 100-113.

Maslach, C., \& Pines, A. Experiencing Social Psychology, Pines, A. New York: Knopf, 1979.

Maslow, A. H., Motivation and personality. New York: Harper, 1954.

Mattingly, M. A. Sources of stress and burn-out in professional child care work. Child Care Quarterly, $1977, \underline{6}, 127-137$.

McGhee, L. C. Psychological signs of executive emotional problems. Industrial Medicine and Surgery, 1963, 32, $180-181$.

McGrath, J. E. Social and psychological factors in stress. New York: Holt, Rinehart \& Winston, 1970.

Mclean, A. Concepts of occupational stress, a review. In A. McLean Occupational Stress. Springfield: Charles C. Thomas, 1974 .

Medvene, A. M. Occupational choice of graduate students in psychology as function of early parent-child interactions. Journal of Counseling Psychology, 1969, $\underline{16}, 385-389$ and $1971, \underline{18}, \frac{1}{422-425}$.

Miller, C. H. Age differences in occupational values of college men. Journal of Counseling Psychology, 1954, 1, 190-192.

Reproduced with permission of the copyright owner. Further reproduction prohibited without permission. 
Morrow, L. The burnout of almost everyone. Time, September $21,1981, \underline{118}, 84$.

Munsterberg, H. Psychology and industrial efficiency. Boston: Houghton-Mifflin, 1913.

Neville, S. H. Job stress and burnout: Occupational hazards for services staff. College and Research Libraries, $1981, \underline{42}, 242-247$.

Norman, B. Career burnout. Black Enterprise, July, 1981, 45-48.

Nunnally, J. C. Educational measurement and evaluation. (2nd ed.). New York: McGraw-Hill, 1972.

Osipow, S. H. Theories of career development. New York: Appleton-Century-Crofts, 1968 .

Osler, W. The Lumkin lectures on Angina Pectoris, The Lancet, $1910,696-700,839-844$, $974-977$.

Perrone, P. A. Values and occupational preferences of junior high school girls. The Personnel and Guidance Journal, 1965, 44, 253-257.

Persson, L., \& Sjoberg, L. The influence of emotions on information processing. Goteborg Psychological Reports, 1978, 으, 7:1-7:82. Peskin, D. The doomsday $\frac{\text { job: }}{\text { turnover. }}$ The behavioral anatomy of
York: Amacon,

Pettigrew, A. Managing under stress. Management Today, 1972, Apri1, 100-102.

Pines, A., Aronson, E., \& Kafry, D. Burnout. New York: The Free Press, 1981.

Pines, A., \& Maslach, C. Characteristics of staff burnout in mental health settings. Hospital and Community Psychiatry, $1978, \underline{29}, 233-237$.

Pines, A., \& Maslach, C. Combatting staff burn-out in a day care center: A case study. Child Care Quarterly, $1980, \underline{9}, 5-16$.

Porter, L. W. A study of perceived need satisfactions in bottom and middle management jobs. Journal of Applied Psychology, 1961, 45, 1-10. 
Porter, L. W., \& Lawler, E. E. Properties of organization structure in relation to job attitudes and job behavior. Psychological Bulletin, 1965, 64, 23-51.

Porter, L. W., \& Lawler, E. E. Managerial attitudes and performance. Homewood: Irwin, 1.968 .

Raths, L. E., Merrill, H., \& Simon S. B. Values and teaching: Working with values in the classroom. Col umbus, Ohio: Merrill, 1966 .

Ricken, R. Teacher burnout: a failure of the supervisory process. National Association of Secondary School Principals Bulletin, $1980, \underline{64,21-24}$.

Roe, A. The psychology of occupations. New York: Wiley, 1956.

Roethlisberger, F. J. \& Dickson, W. J. Management and the worker. Cambridge, Mass.: Harvard University Press, 1939.

Rosen H., \& Weaver, C. G. Motivation in management: A study of four management levels. Journal of Applied Psychology, 1960, 44, 386-392.

Schwartzweller, H. K. Values and occupational choice. Social Forces, 1960, 39, 126-135.

Selye, H. A syndrome produced by diverse nocuous agents. Nature, $1936, \underline{138}, 32$.

Selye, H. The general adaptation syndrome and the diseases of adaptation. Journal of Clinical Endocrinology, $1946, \underline{6}, 117$.

Selye, H. Stress. Montreal: ACTA Medical Publishers, 1950.

Selye, H. Stress without distress. Philadelphia, New York: J. B. Lippincott Co., 1974 .

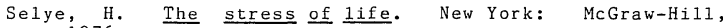
1976.

Sheppard, H. L., \& Herrick, N. Q. Where have al1 the robots gone? New York: Free Press, $\overline{1972 .}$

Special Task Force. Work in America. Cambridge: MIT Press, 1973.

Stefflre, B. Tantative manual for vocational values inventory. Eash Lansing: Michigan State University, 1962.

Reproduced with permission of the copyright owner. Further reproduction prohibited without permission. 
Strong, E. K., Jr. Vocational interests of men and women. California: Stanford University Press, $1 \overline{943}$.

Super, D. E. A theory of vocational choice. American Psychologist, $1953, \underline{8}, 185-190$.

Super, D. E. Work values inventory. Boston: Houghton Miffiin, $19 \overline{68 .}$

Super, D. E. Manual for the Work Values Inventory. Boston: Houghton-Mifflin, 1970 .

Super, D. E., \& Crites, J. 0 . Appraising vocational fitness (rev. ed.) New York: Harper \& Row, $1 \overline{962}$.

Swent, B., \& Gmelch W. Stress at the desk and how to creatively cope. Oregon School Study Council Bulletin, 21, Eugene, Oregon: University of Oregon, 1977.

Tarnowieski, D. The changing success ethic. New York: AMACON, 1973.

Urban W. M. Fundamentals of ethics. New York: Holt, 1930.

Veninga, R. L., \& Spradley, J. P. How to cope with 'job burnout'. Readers Digest, $1981, \underline{119}, 109-112$.

Vroom, V. H. Motivation in management. New York: American Foundation for Management Research, Inc., 1965.

Wardwel1, W. L., Hyman, M. M., \& Bahnson, C. B. Stress and coronary heart disease in three field studies. Journal of Chronic Disease, 1970, 22, 781-795.

Warnath, C. F., \& Shelton, J. L. The ultimate disappointment: The burned-out counselor. Personnel and Guidance Journal, $1976, \underline{55}, 172,175$.

Wax, A. S. An investigation of the reliability, subscale intercorrelations, and validity of the Administrator Role Perceptions Inventory. (Doctoral dissertation, Portland State University, University of Oregon, 1983).

Webber, R. A. The roots of organizational stress. Personne1, $1966, \underline{43}, 5$.

Worthen, R. E. Values, psychology, and existence. Unpublished monograph produced for the members of the Interest Group on Values, National Conference for Professors of Educaional Administration, 1965. (ERIC Document Reproduction Service No. ED 024 128)

Reproduced with permission of the copyright owner. Further reproduction prohibited without permission. 
APPENDIX A

Instruments

Reproduced with permission of the copyright owner. Further reproduction prohibited without permission. 
Dear Administrator

There has been much literature published in the field of stress and burnout. Many professionals have indicated these phenomena are present also in the field of educational administration. If this is so, these characteristics may be related to an individual's role perceptions and work values. Your responses to the enclosed inventories will help determine if such relationships exist.

The instruments you are receiving are: (1) the Administrator Role Perception Inventory; (2) the Ohio Work Values Inventory; and (3) an accompanying Job Data form. To insure confidentiality of all respondents, no individual names will be recorded, nor will the name of your school district be identified.

I know this is a very busy time of the year for you, and I greatly appreciate your taking the time to provide the requested information.

Please enclose your responses in the envelope provided, and return the addressed, sealed envelope.

Again, thank you.

Sincerely

Jacqueline M. Waggoner

Reproduced with permission of the copyright owner. Further reproduction prohibited without permission. 
Please provide the following information:

1. Job Title

2. Sex 3. Age

4. List highest degree plus additional hours and certificates held: Degree Certificates + Hours

5. Years experience at present position (same location, job responsibilities, etc.)

6. Years of work experience as educational administrator

7. Which of these definitions best describes your present job?

- line (a position in the direct line of authority from superintendent to principal or vice-principal, direct and specific accountability for instruction.)

staff (a position whose function is to help line administrators; provides service, support, analysis.)

8. Which of the following most accurately describes your position? central office

_ middle school/junior high school elementary school

How much stress is in your work?

\begin{tabular}{cccccccc}
\hline 0 & 1 & 2 & 3 & $\begin{array}{c}4 \\
\text { mone }\end{array}$ & 5 & 6 & 7 \\
moderate & $\begin{array}{c}6 \\
\text { consider- } \\
\text { able }\end{array}$ & $\begin{array}{c}\text { tremen- } \\
\text { dous }\end{array}$
\end{tabular}

10. How much stress do you feel?

\begin{tabular}{cccccccc}
\hline 0 & 1 & 2 & 3 & $\begin{array}{c}4 \\
\text { moderate }\end{array}$ & 5 & 6 \\
some & & & $\begin{array}{l}6 \\
\text { able }\end{array}$ & 7 & $\begin{array}{c}8 \\
\text { tremen- } \\
\text { dous }\end{array}$
\end{tabular}

11. Please indicate your current level of burnout.

\begin{tabular}{cccccccc}
\hline 0 & 1 & 2 & 3 & $\begin{array}{c}4 \\
\text { mone }\end{array}$ & 5 & $\begin{array}{c}6 \\
\text { consider- } \\
\text { able }\end{array}$ & $\begin{array}{c}8 \\
\text { tremen- } \\
\text { dous }\end{array}$
\end{tabular}

OPTIONAL:

If you wish a summary of the results of this study please provide your name and worksite.

Name

Worksite

Reproduced with permission of the copyright owner. Further reproduction prohibited without permission. 
OHIO WORK VALUES INVENTORY

\section{Directions}

This inventory contains 77 items concerning work values of an individual. Read each statement and decide how strongly you feel about the statement. For each statement, please mark an $X$ on the line which corresponds best to your opinion. 
OHIO WORK VALUES INVENTORY

$$
\begin{array}{lccc}
\text { Not } & \text { A } & \text { Fairly A } & \text { Very } \\
\text { much little } & \text { much lot } & \text { much }
\end{array}
$$

How much would you like to have:

1. a job that helps people?

2. a job where you put things together?

3. a job that is easy for you to keep?

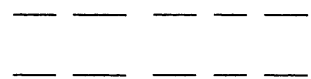

4. a job where you can tell others what to do?

5. a job where you do many of the things you are able to do?

6. a job where you come and go as you please?

7. a job that pays you a lot of money?

8. a job where you do things you like to do?

9. a job that you do mostly by yourself?

10. a job where you often work with facts, ideas and opinions?

11. a job where a lot of people in your state will know what you do?

12. a job where you help people to have a better life?

13. a job where you make or build things?

14. a job that is yours as long as you want it?

15. a job where you would be the boss?

Reproduced with permission of the copyright owner. Further reproduction prohibited without permission. 
Not A Fairly A Very

much little much lot much

How much would you like to have:

16. a job where you can use the skills you have?

17. a job where you choose what you will do each day?

18. a job where you can earn all the money you need and more?

19. a job that gives you a lot of en joyment?

20. a job where you work very little with other people?

21. a job where you sometimes think of new ways to do things?

22. a job that will make you well known?

23. a job where you do good things for others?

24. a job where you can see how and why parts of things fit together?

25. a job you are sure of having year after year?

26. a job where you give directions to other workers?

27. a job that lets you use your abilities?

28. a job where no one tells you what to do?

29. a job where there is a chance to get rich?

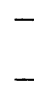

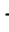

- 
Not A Fairly A Very

much little much lot much

How much would you like to have:

31. a job that is done mostly by one person?

32. a job where having ideas is important?

33. a job where people admire you for your work?

34. a job where you can help people who have problems?

35. a job where your main work is to make or fix things?

36. a job where no one will take your place unless you decide to leave the job?

37. a job where you are in charge of a group of workers?

38. a job that helps you to keep on improving as a person?

39. a job where you decide what hours you will work?

40. a job where you can earn a lot of money?

41. a job that you look forward to doing each day?

42. a job where you are on your own in doing the work?

43. a job where you try to make sense out of several ideas?

44. a job where many people will know you because of your work?

45. a job where you can help people who don't have a very easy life?

46. a job where you take things apart to see why they don't work? 
Not A Fairly A Very

much little much lot much

How much would you like to have:

47. a job that you know is always yours?

48. a job where it is up to you to see that others do their work?

49. a job where you do the things you are good at doing?

50. a job where you can take time off when you want?

51. a job where you may sometimes make a lot of extra money?

52. a job that seems fun to do?

53. a job where you work by yourself most of the time?

54. a job where it is important that others understand your ideas?

55. a job where you have a chance to be famous?

56. a job where doing something for other people is your main work?

57. a job where you often handle things?

58. a job you can keep as Iong as you like?

59. a job where you plan and direct the work of others?

60. a job where you can develop your abilities?

61 a job where you decide how you will do your work?

62. a job that will make you a rich person? 
Not A Fairly A Very

much little much lot much

How much would you like to have:

63. a job that you enjoy doing?

64. a job where you are not near other people much of the time?

65. a job where putting ideas together is important?

66. a job where you will be well known for the work you do?

67. a job that makes living more easy and happy for other people?

68. a job where you use tools in doing your work?

69. a job you know you can always have?

70. a job where others do the work the way you say?

71. a job where you keep improving your skills?

72. a job that you can do your own way?

73. a job that gives you plenty of money?

74. a job where the work you do makes you feel good?

75. a job that you can do alone?

76. a job where developing ideas is important?

77. a job where you get to know some important people?

Reproduced with permission of the copyright owner. Further reproduction prohibited without permission. 
ADMINISTRATOR ROLE PERCEPTION INVENTORY

\section{Directions}

This inventory contains 50 perceptions concerning life as an administrator. Read each statement and decide to what extent you agree or disagree with it. For each statement, please mark an X on the line which corresponds best to your opinion. 
ADMINISTRATOR ROLE PERCEPTION INVENTORY

KEY:

$\mathrm{SD}=$ Strongly Disagree

$\mathrm{D}=$ Disagree

$\mathrm{N}=$ Neutral

$A=$ Agree

$\mathrm{SA}=$ Strongly Agree

SD $\quad$ D $\quad$ N $\quad$ A $\quad$ SA

1. I never expected to spend so much time documenting what I've said and done.

2. I approach my work with less eagerness now.

3. My work depresses me more now than it used to.

4. I have the support of parents.

5. I've made a number of important accomplishments.

6. I thought I'd have more time for creative educational planning.

7. I look forward to going to work.

8. I seldom feel fatigued.

9. Parents and I are able to see each other's point of view.

10. In my job as an administrator, I have a positive effect on other people's lives.

11. I have about as much time for planning as I had expected.

12. I look for ways to lessen my responsibilities.

13. I wish that I did not have to work so closely with other people.

14. It is often difficult for me to establish rapport with parents.

15. I am not an effective administrator.

16. Being a school administrator is no more difficult than I thought it would be.

Reproduced with permission of the copyright owner. Further reproduction prohibited without permission. 
SD $\quad$ D $\quad \mathrm{N} \quad \mathrm{A} \quad \mathrm{SA}$

17. I don't want to go to work.

18. By the end of the day, I'm washed out.

19. Parents used to trust me more than they seem to now.

20. My professional 1ife seems empty.

21. I thought people would be more appreciative of my efforts.

22. I am more motivated than I used to be.

23. Although I work hard, I'm not exhausted at the end of the work day.

24. Students frequent1y smile and speak to me.

25. I suspect that other administrators think I'm not as effective as I used to be.

26. I didn't know that I'd have to spend so many evenings working.

27. I volunteer for special committees less than I used to.

28. My job is more emotionally draining than it used to be.

29. I find myself treating students as if they are a set of variables, rather than as individual people.

30. My recent accomplishments seem to be of little importance.

31. My training gave me a good idea of what to expect in my job.

32. My job provides the right amount of challenge for me.

33. I don't laugh as often as I used to.

34. Staff members tend to contact me orly when they feel it is essential for them to do so. 
SD $\quad$ D $\quad$ N $\quad$ A $\quad$ SA

35. When there's a hard job to be done, people often ask for my help.

36. It is harder to establish priorities than I thought it would be.

37. It is important for me to push myself to be all that I can be.

38. I indulge in self-pity more than I used to.

39. I am more effective now in working with students' problems.

40. I do a good job in handling staff problems.

41. People are more irrational than I had suspected.

42. I frequently initiate changes in order to improve our school.

43. I seldom feel weary.

44. I really do not understand today's students.

45. I can list a number of accomplishments that I have made in the last year.

46. In my job today, I deal with problems I never could have imagined ten years ago.

47. I look for opportunities to further demonstrate my talents and skills to my superiors.

48. I am seldom grouchy.

49. Helping staff learn new ways of working with students has become more important to me.

50. I can now make a more positive impact at work than I could before. 
APPENDIX B

Sample Letters from Researcher to Districts 
Date

Designated District Personnel

School District Address

Dear (Designated Person)

Thank you for the interest you expressed in my proposed research. I will explain my research proposal briefly in this letter and am enclosing a more complete explanation for your review.

Briefly, the problem statement of this research is to investigate the work values of public school administrators, and determine the relationship between public school administrators' role perceptions which are associated with burnout and their work values.

Research in this field of administrator work values and role perceptions is useful in the following respects:

1. This information will help administrators identify the warning signs of burnout in themselves and in their coworkers in order that they may take steps to counteract the effects of burnout and respond more effectively to those who are experiencing problems associated with burnout.

2. Knowledge about factors contributing to burnout among administrators can help school districts restructure activities in order that the work environment will help to satisfy better the needs of administrators.

3. In order to respond to the reported changes taking place in employee work values and to elicit the maximum productivity and creativity from management personnel, school districts need to know the work values of their administrators.

4. Information on administrator work values can aid in the development of an adequate reward system.

5. An understanding of one's work values can help one understand stress factors in the job setting when the job setting does not allow one to achieve those job values.

In order to conduct this research, I would like permission from the (Designated District) for its administrators to fill out two questionnaires. The first is titled Administrator Role Perception Inventory, an instrument originally given to COSA members as part of its validation last August. The second is the Ohio Work Values Inventory, an instrument measuring the work values of administrators. The total time 
involved in completing the two questionnaires is approximately 15 to 20 minutes. Confidentiality of the respondents will be maintained, and the identity of your district will not be disclosed in the reporting of the results.

I would like the administrators to complete the questionnaires during the Spring of 1983. I am hoping to have my dissertation completed in late summer or early fall. At that time, I will share the results of my research with the (Designated School District). Additionally, I would be happy to be involved in the development of follow-up activities.

The method of dissemination and collection of the questionnaires is flexible. These procedures will be finalized in conjunction with your district to allow for a minimum of disruption in your administrative routines.

If you or your staff have any questions, please feel free to contact me. I will be looking forward to hearing from you after your review of the enclosed materials. I can be contacted at (numbers given).

Thank you for taking the time to review this material. I am hopeful you will find this study worthwhile for (Designated District) administrator participation.

Sincerely

Jacqueline M. Waggoner

Enclosures

Reproduced with permission of the copyright owner. Further reproduction prohibited without permission. 
Date

(Designated Person in District)

School District

Dear (Designated Person)

Thank you, again, for your thoughtful consideration of allowing (Designated District) administrator participation in this research study.

I have brought (Designated number) packets of questionnaires and addressed them with both our names to facilitate their identification upon their return to your office. If possible, I would like administrators to return the questionnaires within one week of the time they are disseminated. At the time it appears that the majority of the questionnaires have been returned, please have your secretary call, and I will pick them up.

I am looking forward to sharing the results of this study with you and your administrators and will gladly participate in any follow-up activities.

Again, thank you so much for your assistance in collecting this information. I really appreciate all your help. I realize this takes your time and an investment on your district's part to extend yourselves to participation in research activities.

I can be contacted at (numbers given). Please feel free to contact me if you have any questions.

Very Sincerely

Jacqueline M. Waggoner

Reproduced with permission of the copyright owner. Further reproduction prohibited without permission. 
APPENDIX C

Sample Memos from Districts to Their Administrators 
Date

TO: $\quad$ Administrators

FROM: $\quad$ (Designated Person)

RE: $\quad$ Attached Survey Instruments

The attached survey instruments are being sent to you as part of a District sanctioned external research project being conducted by Ms. Jackie Waggoner. They can be completed in 20 minutes or less.

The purpose of the research is to investigate the relationship between how educational administrators view their work and the values which they bring to the job. It is expected that this analysis will help pinpoint sources of stress and dissatisfaction for administrators that can be dealt with. As such, it represents a potentially important contribution to our effort to improve the quality of work life within our administrative team and throughout the District as a whole.

Several key points to note in deciding whether to respond to these three brief survey instruments are:

1) Your participation is both completely voluntary and anonymous. Please do not give your name and feel free to leave any information off the initial job data survey that may be uniquely identifying.

2) The group analysis of the results of this study for the District and for the entire sample of districts will be made available to individual administrators and administrator groups.

If you choose to respond to these survey instruments, please return them through the intradistrict mail system by (date and location given).

Thank you for your consideration and cooperation. 


\section{MEMORANDUM}

TO: Administrative Staff

FROM: (Designated Person)

Re: Approved Study of Administrative Stress and Burnout

Jackie Waggoner, a doctoral candidate in school administration, has received permission from (The Superintendent) to pursue the collection of data for her degree. Please assist Ms. Waggoner in obtaining her data by:

1) Reading the accompanying cover letter.

2) Completing the two surveys
a) Administrator Role Perception Inventory
b) Ohio Work Values Inventory

3) Completing the job data sheet. (Job title may be general, if yours will identify you.)

The surveys have been piloted to take no more than 15 minutes.

Please return the materials in the accompanying envelope. Seal the envelope for confidentiality.

Return these envelopes to (designated place) by (date).

Please know that (Designated District) will receive a printout of the aggregated results by next fall. These will be shared with you.

Reproduced with permission of the copyright owner. Further reproduction prohibited without permission. 
Date

To: $\quad$ ALL ADMINISTRATORS

FROM: (DESIGNATED PERSON)

We have received a request from Jacqueline $M$. Waggoner to take part in a research project involving administrators in Oregon and Washington. It is a follow up on Anne Wax's study of last year.

The (Designated Department) has approved the request and while your participation is optional we would like you to spend about 15 minutes completing the enclosed questionaire. We will receive district results and a copy of the total study report in the fall.

Please return the completed survey to me in the envelope by (Date). 
APPENDIX D

Notable Respondents' Comments

Reproduced with permission of the copyright owner. Further reproduction prohibited without permission. 


\section{NOTABLE COMMENTS}

\section{COMMENT 1}

An important comment on item 50 (ARPI). I am far more skilled now than $I$ was several years ago and should therefore be able to have more positive impact. However, I have become worn down by the closed, irrational, hiddenagenda behavior of peers and upper level administrators and currently feel more impotent than when I first began in administration. In my early years, I believed I could make a difference, and I did. My programs have succeeded beyond all expectation. I now feel other administrators undermine these programs. There is no open discussion. It is frustrating when I am not treated by my peers and superiors with that same respect I give them. I love working with teachers and students, but that joy is more and more undermined by frustrations of closed, manipulative administrative structures.

\section{COMMENT 2}

I feel that the most time-consuming item in administration today is financing. It may also be one of the most stressful as wel1. I feel I spend far too much time in this area. I would much rather spend time in curriculum and in the learning process, in different learning styles of students and in staff development. I've been in education for 25 years, 11 years as a teacher and 14 years as a principal. If I were just entering the world of work and knew what I know now, I would change very little. I love working with kids, parents and teachers. You never know when your dividends will arrive. Just the other day a young mother came up and said, "I moved to your attendance area so my kids could go to your school, because you were my grade school teacher, and I know you' 11 see that they get the best education has to offer." Wow! what a neat dividend. There have been others. This is just the most recent. I look forward to coming to work every day. 
APPENDIX E

Previous ARPI Means and Standard Deviations

Reproduced with permission of the copyright owner. Further reproduction prohibited without permission. 
The following are the means and standard deviations reported by Wax (1983, p. 75) in her research with members of the Confederation of Oregon School Administrators (COSA).

\section{TABLE LXIX}

PREVIOUS ARPI MEANS AND STANDARD DEVIATIONS

\begin{tabular}{lcc}
\hline \multicolumn{1}{c}{ Subscale } & Mean & Standard Deviation \\
\hline Expectation & 28.07 & 5.44 \\
Motivation & 35.30 & 4.71 \\
Psycho-physical State & 32.96 & 6.44 \\
Relationships & 39.07 & 4.29 \\
Accomplishment & 39.72 & 4.14 \\
Time* & 28.68 & 4.71 \\
Toial ARPI & 175.12 & 19.17 \\
*Time is an eight-item scale. & &
\end{tabular}

